\title{
Listening for the Cosmic Other: Postcolonial Approaches to Music in the Space Age
}

Paige Zalman

West Virginia University, paz0002@mix.wvu.edu

Follow this and additional works at: https://researchrepository.wvu.edu/etd

Part of the Musicology Commons

\section{Recommended Citation}

Zalman, Paige, "Listening for the Cosmic Other: Postcolonial Approaches to Music in the Space Age" (2019). Graduate Theses, Dissertations, and Problem Reports. 3797.

https://researchrepository.wvu.edu/etd/3797

This Thesis is protected by copyright and/or related rights. It has been brought to you by the The Research Repository @ WVU with permission from the rights-holder(s). You are free to use this Thesis in any way that is permitted by the copyright and related rights legislation that applies to your use. For other uses you must obtain permission from the rights-holder(s) directly, unless additional rights are indicated by a Creative Commons license in the record and/ or on the work itself. This Thesis has been accepted for inclusion in WVU Graduate Theses, Dissertations, and Problem Reports collection by an authorized administrator of The Research Repository @ WVU. For more information, please contact researchrepository@mail.wvu.edu. 
"Listening for the Cosmic Other: Postcolonial Approaches to Music in the Space Age"

Paige Zalman

\author{
Thesis submitted \\ to the College of Creative Arts \\ at West Virginia University \\ in partial fulfillment of the requirements for the degree of \\ Master of Arts in \\ Musicology
}
Travis Stimeling, Ph.D., Chair
Evan MacCarthy, Ph.D.
Matthew Heap, Ph.D.

School of Music

Morgantown, West Virginia

2019

Keywords: musicology, postcolonial studies, space, film, string quartet, playlist

Copyright 2019 Paige Zalman 


\begin{abstract}
Listening for the Cosmic Other: Postcolonial Approaches to Music in the Space Age
\end{abstract}

Paige Zalman

As government programs such as NASA and SETI seek signs of intelligent life in space and privately-funded programs such as SpaceX finalize plans to colonize Mars in the coming decades, representations of space and extraterrestrial life in American culture have become increasingly relevant. Focusing on Jóhann Jóhannsson's musical score for Denis Villeneuve's science-fiction film Arrival (2016), Terry Riley's Sun Rings (2002) for string quartet, chorus, and recorded space sounds, and former International Space Station Commander Chris Hadfield's "Songs about Space" Spotify playlist, my research problematizes the ways in which composers, musicians, and even astronauts depict alterity through music and reinforce colonial narratives about outer space. Drawing upon the work of postcolonial theorists and musicologists such as Charles Forsdick (2003), Olivia A. Bloechl (2008), Ania Loomba (2015), and others, this thesis argues that musical depictions of extraterrestrials and space exploration, more generally, reveal the potential for discrimination, misrepresentation, and abuses of power to emerge from space colonization. But, back on Earth, this study also suggests that such fraught theoretical relationships between human colonists and extraterrestrials echo the real-life suffering of colonized indigenous groups and the necessity of decolonization. 


\section{Table of Contents}

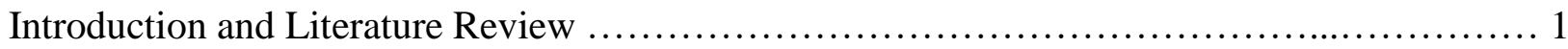

Postcolonial Studies: A Brief Overview ........................................ 4

Postcolonial Studies and Music .................................................... 7

Music and Outer Space ......................................................... 10

Conclusion and Chapter Outline ................................................. 14

1. Colonial Encounters, Alien Languages, and the Exotic Music of Denis Villeneuve's

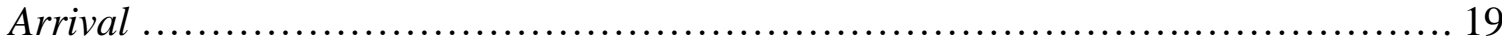

Jóhannsson's Musical Score to Arrival ............................................. 24

Musical Othering in Science-Fiction More Broadly ................................... 32

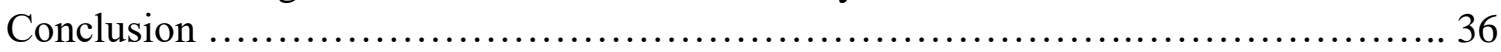

2. "Reach[ing] Out from Earth": Colonialist Ideologies, Sounds from Space, and Terry

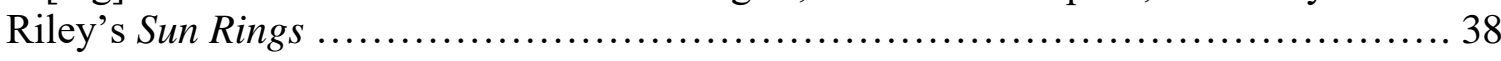

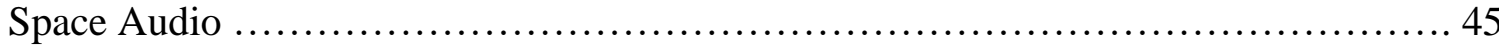

Sun Rings: Reception and Analysis .............................................. 49

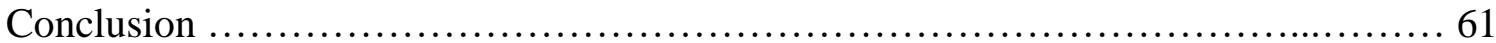

3. Hearing Space through an Astronaut's Ears: Colonial Themes and Masculinity in Chris

Hadfield's "Songs about Space" Spotify Playlist .................................... 64

Songs about (Men in) Space ..................................................... 73

Songs about (Men in) Space: Readings on Shuffle ............................... 81

Conclusion: The Genesis of a Space Topos .................................. 85

Conclusions: Postcolonial Earth, Precolonial Space _....................................... 89

Hybridity and Music ............................................................ 90

The Trump Administration, American Nationalism, and the Space Force ............. 92

Beyond Earth: Future Directions ............................................... 97

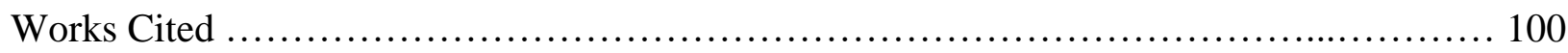




\section{Introduction and Literature Review}

"If aliens visit us, the outcome would be much as when Columbus landed in America, which didn't turn out well for the Native Americans. We only have to look at ourselves to see how intelligent life might develop into something we wouldn't want to meet." - Stephen Hawking ${ }^{1}$

Stephen Hawking was not the first to express pessimism about the idea of encountering intelligent extraterrestrial life. Negative images of human-extraterrestrial relationships permeate science-fiction literature and films. While some depictions are intentionally scary and singleminded, like the Alien and Predator franchises, other representations have more depth, often revealing a critical miscommunication between humans and aliens that led to what could have been avoidable violence or war, as in Orson Scott Card's Ender's Game book series or the 2016 film Arrival. ${ }^{2}$ Yet despite these thematic differences, extraterrestrials are nonetheless portrayed as frightening, savage, and unmerciful across the science-fiction genre almost without exception. Hawking's comparison to Native Americans is particularly appropriate in this case, since settlers of the New World viewed the indigenous population in much the same way that films and literature tend to depict extraterrestrials in modern culture. As our ability to explore further reaches of space increases exponentially, and along with it the possibility of contact with intelligent life should it exist, the potential for colonialism becomes very real once again. And while the idea of space colonization is a thrilling one, especially as climate change continues to worsen and our planet's resources continue to dwindle, the thought also carries fear, as Hawking has demonstrated.

\footnotetext{
${ }^{1}$ Stephen Hawking, Into the Universe with Stephen Hawking, documentary, directed by Darlow Smithson Productions Limited (Discovery Channel, 2010).

${ }^{2}$ See Orson Scott Card, Ender's Game (New York: Tor Science Fiction, 1994), and Denis Villeneuve, director, Arrival, DVD, Paramount Pictures, 2016.
} 
At its core, colonialism is synonymous with exploitation, subjugation, and dehumanization. Scholars of postcolonial studies, an academic field that explores both the immediate and lasting effects of colonization on the individual and society, have demonstrated this sad truth across numerous case studies. The field's broad and ever-relevant inquiries concerning identity, representation, power, race, class, and gender have practical applications within every subfield of the humanities, though postcolonial studies has received relatively little attention within the field of musicology. The purpose of this literature review then, while not comprehensive, is to assess the current state of academic scholarship which engages simultaneously with music and postcolonial studies to convey the ways in which postcolonial studies can and has been used to better understand musical depictions of the Other. As my larger thesis more specifically seeks to explore representations of the extraterrestrial Other in music, this literature review will also engage with academic works in which music and outer space or space beings intersect with one another. I will first examine works by past and current scholars of postcolonial studies to provide a brief explanation of the field's primary research concerns, then segue into a discussion of musicological literature that uses postcolonial studies (or related methodologies, such as exoticism or orientalism) as a framework to study music of the Other. I will then conclude with an overview of recent research about the intersection of music and outer space before providing a brief chapter outline of the larger thesis. In so doing, I hope to demonstrate not only the need for more postcolonial studies research within the field of musicology, but also the relevance of studying the extraterrestrial Other, which can apply not only to our future space endeavors but also to our terrestrial sociopolitical relationships here on Earth. 
Before delving into an overview of postcolonial studies, however, a brief discussion of the current state of space colonization is necessary. While once a farfetched dream, plans have already begun to colonize the planet Mars. Elon Musk and SpaceX assert on their website that their "aspirational goal is to send [their] first cargo mission to Mars in 2022," closely followed in 2024 by " [a] second mission, with both cargo and crew, [...] with primary objectives of building a propellant depot and preparing for future crew flights." Their ultimate goal, they write, is "to build a thriving city and eventually a self-sustaining civilization on Mars." ${ }^{3}$ The organization MarsOne used to share this same aspiration before its bankruptcy in January 2019; their website still declares their intention to send a crew to the red planet in the year 2031, though without finances, it is unlikely that this venture will succeed. ${ }^{4}$ Nonetheless, this eagerness to establish human civilization on Mars is a modern day Space Race, an echo of the spaceflight technology rivalry between the United States and the Soviet Union during the Cold War. Meanwhile, companies like the Deep Space Institute and Planetary Resources have already begun to develop plans to mine space resources from asteroids. ${ }^{5}$ Management/Space Psychologist Philip R. Harris is also interested in harvesting of space resources; in his book Space Enterprise: Living and Working Offworld in the $21^{\text {st }}$ Century, Harris explores space colonization from a behavioral science perspective, examining the pros and cons of space industrialization and suggesting possible approaches to lunar economics. ${ }^{6}$ In fact, the idea of packing up and moving to space is such a compelling possibility for some that Neil Leach's edited volume Space Architecture: The

\footnotetext{
3 "Mars," SpaceX, accessed April 20, 2018, http://www.spacex.com/mars.

4 "Roadmap," MarsOne, accessed April 20, 2018, https://www.mars-one.com/mission/roadmap. On the organization's bankruptcy, see Eric Berger, "To Almost No One's Surprise, Mars One is Done [Updated]," Ars Technica, February 11, 2019, https://arstechnica.com/science/2019/02/to-almost-no-ones-surprise-mars-one-isdone/.

5 Jesse Dunietz, “Space Prospecting," Scientific American 317 (October 2017): 14-16. https://libwvu.on.worldcat.org/oclc/7079260005.

${ }^{6}$ Philip R. Harris, Space Enterprise: Living and Working Offworld in the 21 st Century (Berlin: Praxis, 2009).
} 
New Frontier for Design Research explores the architectural designs behind space settlements, habitable artificial satellites, and space tourism, among others. ${ }^{7}$ Considering all of this, it appears that space colonization an imminent reality. There are, however, considerable ethical concerns with such an endeavor, and postcolonial studies can provide a useful framework in exploring the reasons why space colonization might not be an endeavor to celebrate.

\section{Postcolonial Studies: A Brief Overview}

Like feminist studies, queer studies, and other academic fields concerned with the study of underrepresented populations, postcolonial studies emerged within the new humanities around the 1970s and 1980s. Postcolonial studies' genesis is frequently attributed to authors Frantz Fanon and Edward W. Saïd, while scholars like Gayatri Chakravorty Spivak and Homi K. Bhabha are often noted as two of postcolonial studies' more recent leading thinkers. First chronologically came Fanon's influential books Peau Noire, Masques Blancs (Black Skin, White Masks, 1953) and Les Damnés de la Terre (The Wretched of the Earth, 1961), both of which explore the psychological effects of colonization on the individual and society, with the latter work especially focusing on the need for revolution as well as the psychological effects of the binaries within language that separate the colonizer and the colonized, or the master and the slave. ${ }^{8}$ Fanon's works were followed in 1978 by Saïd's Orientalism, a book frequently cited as the first postcolonial studies text, which examines problematic and false representations of the

\footnotetext{
${ }^{7}$ Neil Leach, ed., Space Architecture: The New Frontier for Design Research 84, no. 1 (West Sussex: John Wiley and Sons, Inc., 2014).

${ }^{8}$ Frantz Fanon, Les Damnés de la Terre (Paris: F. Maspero, 1961), translated by Richard Philcox as The Wretched of the Earth (New York: Grove Press, 2004); see also Frantz Fanon, Peau Noire, Masques Blancs (Paris: Editions Du Seuil, 1953), translated by Richard Philcox as White Skin, Black Masks (New York: Grove Press, 1967). Fanon's works were especially influential in the United States' 1960s Civil Rights Movement as well as in formerly colonized countries in Africa and the Carribean.
} 
East by the imperialist West. ${ }^{9}$ Ten years later, Spivak's 1988 essay “Can the Subaltern Speak?" brought to the fore issues of agency in representations of what Spivak has termed the "subaltern" Other, while Bhabha's 1994 The Location of Culture explains colonialism and its modern-day effects on identity through a theory of cultural hybridity. ${ }^{10}$ The central themes explored by these scholars - racism, representation, power, agency, identity - are the foundation of postcolonial studies, and these scholars' contributions in particular have been largely influential in the rest of the works that I discuss in this section.

Two texts that can provide a thorough explanation of the field's history and its most important aspects in contemporary academia are Leela Gandhi's Postcolonial Theory and Ania Loomba's Colonialism/Postcolonialism. ${ }^{11}$ Gandhi's work not only recounts the schools of thought that led to the dawn of postcolonial studies, such as poststructuralism and Marxism, but also the intellectual movements that justified the practice of colonialism, such as Cartesianism and the Enlightenment, which glorified conquest and domination. ${ }^{12}$ Gandhi also engages with feminist postcolonial thought and the complex issues within that area of the field concerning the troubling lack of agency of oppressed women and, conversely, the inaccurate tendency of postcolonial scholars to homogenize the intentions of first world feminists. In addition, Gandhi reminds readers that postcolonial studies at its core is a critique of history considering that history itself is the discourse by which the West has proclaimed its own dominance.

\footnotetext{
${ }^{9}$ Edward W Saïd, Orientalism (New York: Pantheon Books, 1978).

${ }^{10}$ Gayatri Chakravorty Spivak, "Can the Subaltern Speak?" Marxism and the Interpretation of Culture, ed. Cary Nelson and Larry Grossberg (Chicago: University of Illinois Press, 1988), 271-313; see also Homi K. Bhabha, The Location of Culture (New York: Routledge, 1994).

${ }^{11}$ Leela Gandhi, Postcolonial Theory (New York: Columbia University Press, 1998); see also Ania Loomba, Colonialism/Postcolonialism, 3rd edition (London: Routledge, 2015).

${ }^{12}$ It is important to note that Fanon was greatly influenced by his teacher Aimé Césaire (a co-founder of the Négritude movement) and by certain elements of Marxist thought, while Saïd's work draws upon aspects of poststructuralism. Because of this, certain ideas within postcolonial studies can be traced back to these earlier intellectual movements.
} 
Similarly, Loomba's publication also traces the intellectual influences from which postcolonial studies was born, though she is also concerned with modern day manifestations of colonialism through capitalism and globalization, an idea with which Gandhi only briefly engages. While at times Gandhi's text appears to point to more problems within the field of postcolonial studies than solutions, Loomba's book more often draws attention to the positives of the field, including the opportunity to see from new perspectives through postcolonial literary texts and the benefits that could arise from applying postcolonial studies to environmental issues and climate change. Yet Loomba and Gandhi agree that Western feminism has much to learn from postcolonial studies about representation and the complexity of the hybrid identities of previously colonized populations.

Edited volumes such as the Oxford Handbook of Postcolonial Studies demonstrate the field's wide application and its highly interdisciplinary nature. ${ }^{13}$ Divided into five subsections, the essays within this volume approach postcolonial studies from a variety of angles; for instance, Ann Laura Stoler, like Leela Gandhi, applies the ideals of the Enlightenment to explain imperialism, while Timothy Brennan explores the conflicting postcolonialist interpretations of Hegel's philosophies. ${ }^{14}$ Scholars like Stephan Morton and Joanne Sharp assert links between violence, 9/11, and the colonial present in the United States and Africa. ${ }^{15}$ As Ania Loomba had proposed, Dana Mount and Susie O'Brien demonstrate the importance of merging postcolonialist

\footnotetext{
${ }^{13}$ Graham Huggan, ed., The Oxford Handbook of Postcolonial Studies (Oxford: Oxford University Press, 2013).

${ }^{14}$ Ann Laura Stoler, "Reason Aside: Reflections on Enlightenment and Empire," The Oxford Handbook of Postcolonial Studies, ed. Graham Huggan (Oxford: Oxford University Press, 2013), 39-66; see also Timothy Brennan, "Hegel, Empire, and Anti-Colonial Thought," The Oxford Handbook of Postcolonial Studies, ed. Graham Huggan (Oxford: Oxford University Press, 2013), 142-161.

${ }^{15}$ Stephan Morton, "Violence, Law, and Justice in the Colonial Present," The Oxford Handbook of Postcolonial Studies, ed. Graham Huggan (Oxford: Oxford University Press, 2013), 179-196; see also Joanne Sharp, "Africa's Colonial Present: Development, Violence, and Postcolonial Security," The Oxford Handbook of Postcolonial Studies, ed. Graham Huggan (Oxford: Oxford University Press, 2013), 235-252.
} 
thought with environmental studies, while other disciplines such as literature, history, and even the social sciences are combined with postcolonial studies in the volume's other essays. ${ }^{16}$

The last subsection of the Oxford Handbook is a testament to the wide variety of geographic locations to which postcolonial studies has been applied. These essays explore colonialism and globalization in Asia, the Pacific, Africa, America, and Europe. Other edited volumes, such as Francophone Postcolonial Studies: A Critical Introduction, are devoted solely to comparing and contrasting the colonial experience across certain geographic locations. ${ }^{17}$ As French-speaking areas can be found in Asia, the Atlantic, Africa, and North America, the latter volume serves as an investigation of the role that language plays in identity formation, as well as the effects of globalization and French culture in these areas.

\section{Postcolonial Studies and Music}

While postcolonial studies could be applied with more frequency as a framework for musicological research, only a few scholars have thus far attempted to draw upon the theory. One of the best examples of postcolonial studies within musicology is Olivia A. Bloechl's Native American Song at the Frontiers of Early Modern Music. ${ }^{18}$ Her book explores the influence of Native American music being made in the New World on the English and French in the sixteenth and seventeenth centuries, seeking to capture a more accurate construction of music history that addresses the connections between colonial violence and musical performances. The first half of her book explores connections between Protestant settlers' qualms with Catholic music and their

\footnotetext{
${ }^{16}$ Dana Mount and Susie O'Brien, "Postcolonialism and the Environment," The Oxford Handbook of Postcolonial Studies, ed. Graham Huggan (Oxford: Oxford University Press, 2013), 521-539.

${ }^{17}$ Charles Forsdick and David Murphy, eds, Francophone Postcolonial Studies: A Critical Introduction (London: Arnold, 2003).

${ }^{18}$ Olivia A. Bloechl, Native American Song at the Frontiers of Early Modern Music (New York: Cambridge University Press, 2008).
} 
similar negative interpretation of Native American music. In the second half, Bloechl examines music of the English court, as well as compositions by Lully and Rameau, to demonstrate the ways in which Native Americans were musically portrayed as exotic, primitive, and savage in Europe, thus musically reinforcing colonial ideals.

In addition to scholarship on Native Americans in the New World, music of the black Atlantic diaspora has been another theme in postcolonial musicological scholarship. For instance, Paul Gilroy's The Black Atlantic: Modernity and Double Consciousness posits that the mass migration from Africa promoted "countercultures of modernity" within the AfricanAmerican community, especially through black music. ${ }^{19}$ Drawing upon this important historical analysis, Simon uses case studies to explore various types of non-Western music such as calypso and Apache Indian through Gilroy's postcolonial theory of music. ${ }^{20}$ Likewise, Tina K. Ramnarine's article "Musical Performance in the Diaspora: Introduction" engages with music of the Caribbean Diaspora in Britain to explore the disjuncture between the representations and the reality of musical performance in the diaspora, which she concludes is a complex and multicultural musical display that should be dealt with carefully through ethnographic work. ${ }^{21}$ These three pieces especially are important contributions to postcolonial studies in their simultaneous engagement with music, race, and the black Atlantic diaspora.

An early intervention in the field, Georgina Born and David Hesmondhalgh's Western Music and Its Others: Difference, Representation, and Appropriation in Music explores various

\footnotetext{
${ }^{19}$ Paul Gilroy, The Black Atlantic: Modernity and Double Consciousness (Cambridge, MA: Harvard University Press, 1993).

${ }^{20}$ Simon Featherstone, "Music, ” Postcolonial Cultures, ed. Simon Featherstone (Edinburgh: Edinburgh University Press, 2005), 33-64.

${ }^{21}$ Tina K. Ramnarine, "Musical Performance in the Diaspora: Introduction," Ethnomusicology Forum 16, no. 1 (2007): 13 .
} 
frameworks by which scholars can better theorize about difference in Western music. ${ }^{22}$ The introduction especially makes a case for postcolonial studies as an appropriate framework for such research. The editors argue that postcolonial studies' emphasis on culture and knowledge's role in power relations could provide a more thorough understanding of the marginalization of certain populations through an examination of musical difference. However, rather than follow through with their own suggestions, the editors of the volume chose instead to include various essays which engage with music and race, class, and power through other methodologies, citing as their reason the relative absence of postcolonial scholarship within the field of musicology at the time of publication eighteen years ago. Similar frameworks that have been historically more popular than postcolonial studies in recent musicological research are orientalism (based largely on the writings of Saïd) and exoticism.

Musicologists Susan McClary, Jonathan Bellman, and Ralphe Locke have drawn heavily upon Saïd's Orientalism. ${ }^{23}$ McClary's research on Bizet's Carmen is one of the first works to engage with orientalism within the genre of opera. Her analysis is also heavily influenced by feminist studies, and engages with race, class, and gender to explore musical exoticism within the opera. Unlike McClary's work, Bellman’s study does not apply orientalism to a specific musical work but rather contrasts various frameworks, including orientalism and postcolonial criticism, to demonstrate the need for critical approaches that acknowledge the reciprocal exchange of cultural and musical ideas between oppressed people and oppressors.

\footnotetext{
${ }^{22}$ Georgina Born and David Hesmondhalgh, "Introduction: On Difference, Representation, and Appropriation in Music," Western Music and Its Others: Difference, Representation, and Appropriation in Music, ed. Georgina Born and David Hesmondhalgh (Berkeley: University of California Press, 2000), 1-58.

${ }^{23}$ Susan McClary, Georges Bizet: Carmen (Minneapolis: University of Minnesota Press, 1992); Jonathan Bellman, "Musical Voyages and Their Baggage: Orientalism in Music and Critical Musicology," Musical Quarterly 94 (2011): 417-438.
} 
Bellman is perhaps more well-known for his work on exoticism more generally; his edited volume The Exotic in Western Music is a compilation of several leading scholars' takes on exoticism in various geographic locations and through various musical idioms. ${ }^{24}$ Bellman's own contributions to this volume include a chapter that examines the frequent evocation of exotic musical styles associated with Hungarian Gypsies within European art music beginning around the eighteenth century, as well as a piece about East Indian musical influence on 1960s popular music artists such as the Beatles. In a similar book titled Musical Exoticism: Image and Reflections, Ralph P. Locke explores exoticism in Western music across several genres beginning in the Baroque era and concluding with an analysis of Tan Dun's 1996 opera Marco Polo. ${ }^{25}$ Locke's analysis across such a broad time span allows him to trace exoticist musical trends across Western history while also engaging with the effects of colonialism on musical composition and representations.

\section{Music and Outer Space}

As demonstrated above, music scholars have applied postcolonial studies and related methodologies to a large variety of genres, nationalities, and historical eras. As I will establish in my larger thesis, these same questions about representation and identity in the exotic music of the Other can also be applied to outer space music and music depicting extraterrestrials. Though no scholars have yet used postcolonial studies as a lens for examining these kinds of music, several have written about the intersection of space and various genres of music.

In the realm of popular music, space exploration has been a recurring theme for the past several decades, and in one case has even inspired an entire genre. The terms "new-age" or

${ }^{24}$ Jonathan Bellman, ed., The Exotic in Western Music (Boston: Northeastern University Press, 1998).

${ }^{25}$ Ralph P. Locke, Musical Exoticism: Image and Reflections (Cambridge: Cambridge University Press, 2009). 
"space music" are used to describe a jazz fusion sound that often relies on drones and other meditative musical sounds to evoke a celestial feel. ${ }^{26}$ Some performers of new-age music, like Connie Cook, a resident of Peoria, Illinois, even claim to have been inspired to perform by their encounters with extraterrestrials who gifted them with other-worldly musical ability. ${ }^{27}$ In another musical genre also inspired by space, Shannon Finck writes about the intersection of "geek rock" and outer space in her chapter "Man [Seeking] Astro-Man?: Nouveau Surf Rock and the Futuristic-Past Nostalgic." Finck argues that the "(un)popular" band Man or Astro-man?, active since the early 1990s, exemplifies a nostalgia for the 1960s mid-Space Race American dream of space colonization while also evoking futuristic images through experimental sounds and astronaut-themed costumes and performance sets. ${ }^{28}$ But even in less "geeky" social scenes, like the jazz scene, ideas about extraterrestrials and outer space permeate music. The artist Sun Ra in particular was known for incorporating "space-gospel" elements into his bluesy jazz style; he also claimed to have been born on the planet Saturn. ${ }^{29}$ Similarly, in the progressive rock realm, scholar Kevin Holm-Hudson has explored otherness in music of the band Magma, who not only drew upon the music of John Coltrane but also created their own alien language in which most of their songs' lyrics are written and sung. ${ }^{30}$ In fact, so many musicians have claimed to be aliens or used an extraterrestrial persona on stage that William Tsitsos has written about the phenomenon as it pertains to race, suggesting that, for musicians of color, adapting an extraterrestrial persona

\footnotetext{
${ }^{26}$ Joseph Lanza, "Violins from Space," Elevator Music: A Surreal History of Muzak, Easy-Listening, and Other Moodsong (Ann Arbor: University of Michigan Press, 2004), 183-94.

${ }^{27}$ Robert Johnson, "Outer-Space Tunes Make Earth Debut in a Bar in Peoria --- Pianist-Singer Claims Aliens Taught Her their Music; Do They Get Royalties?” Wall Street Journal, September 4, 1990.

${ }^{28}$ Shannon Finck, "Man [Seeking] Astro-Man?: Nouveau Surf Rock and the Futuristic-Past Nostalgic," Geek Rock: An Exploration of Music and Subculture, ed. Alex DiBlasi and Victoria Willis (Lanham: Rowman \& Littlefield, 2014), 124-137.

${ }^{29}$ Walter Crockett, “Sun Ra: Jazz Man from Outer Space," Worcester Telegram \& Gazette (MA), D1 (February 1, 1990).

${ }^{30}$ Kevin Holm-Hudson, "Apocalyptic Otherness: Black Music and Extraterrestrial Identity in the Music of Magma," Popular Music and Society 26, no. 4 (2003): 481-95.
} 
offers an opportunity to be in control of their own image rather than be defined and labeled by race and the associated societal connotations. ${ }^{31}$

Images of space and extraterrestrials have also infiltrated art music; one needn't look further than Gustav Holst's The Planets, composed near the beginning of the twentieth century, to find evidence of this cosmic influence. Additionally, the avant-garde composer Karlheinz Stockhausen is also known for an interest in outer space and spatial music. In "An Adventure into Outer Space: Stockhausen's Lichter-Wasser and the Analysis of Spatialized Music,” Paul Miller uses several techniques like measuring distances, speeds, and densities of Stockhausen's musical material to analyze one of the composer's complex pieces of spatial music. ${ }^{32}$ More recently, in a more literal sense of the term "space music," the musical group Flow Motion has created musical soundings of the data from Cygnus X1 (a black hole first discovered in 1964) in a multimedia project called Astro Black Morphologies/Astro Dub Morphologies that celebrates science, music, and the legacy of black artists like Coltrane and Sun Ra (whose 1972 composition inspired the project's title). The group was inspired after two scientists suggested that the data readings of Cygnus X1 were "implicitly musical in structure" due to vibration patterns. ${ }^{33}$

Flow Motion is not the only group interested in the musical potential of data recordings from space. For instance, Stefan Helmreich has conducted research on gravitational wave-sounds from space after scientists translated the vibrations made by two colliding black holes into a sound wave that resembled a "chirp." ${ }^{34}$ David Rosenboom, on the other hand, has drawn

\footnotetext{
${ }^{31}$ William Tsitsos, "Racial Transparency Theory Applied to Musicians who Claim to Be Aliens," Popular Music \& Society 37, no. 1 (2014): 22-32.

32 Paul Miller, “An Adventure into Outer Space: Stockhausen's Lichter-Wasser and the Analysis of Spatialized Music," Perspectives of New Music 50, no. 1-2 (2012): 342-92.

${ }^{33}$ Flow Motion. “Astro Black Morphologies: Music and Science Lovers.” Leonardo 39, no. 1 (2006): $23-27$.

34 Stefan Helmreich, "Gravity's Reverb: Listening to Space-Time, or Articulating the Sounds of Gravitational-Wave Detection," Cultural Anthropology 31, no. 4 (2016): 464-92, doi:10.14506/ca31.4.02.
} 
intriguing parallels between composer-performers of music and SETI astronomers (scientists who work on the Search for Extraterrestrial Intelligence project) in his article "Music Notation and the Search for Extra-Terrestrial Intelligence." ${ }^{35}$ Rosenboom argues that the astronomers' interpretation of data, i.e. a message from space, is a form of communication (possibly from intelligent extraterrestrial life), just as musical notation communicates "musical intelligence" to the performer whose job it is to interpret it. For Willard Van De Bogart, though, this communication goes both ways; Van De Bogart has written about his experiences in the Southern California desert, where he attempted to communicate with extraterrestrials through a musical composition using sound technologies like synthesizers, VLF radio receivers, and recordings. ${ }^{36}$

Of the scholarship that bridges the subjects of musicology and outer space, the piece that is perhaps closest to my own research aspirations for the larger thesis is Tim Summers' article "Star Trek and the Musical Depiction of the Alien Other." 37 Though Summers does not explicitly use postcolonial studies as a framework as I will in my own explorations of musical representations of extraterrestrials, he does explore the ways in which the composers' music contributes to the image of alterity in the alien races of the Star Trek franchise. He applies theories of hybridity, orientalism, and other related methodologies to contrast the types of musical Othering used for specific characters, ultimately demonstrating that the aliens' Otherness is created musically often through ominous sound effects and motivic material that is in stark

\footnotetext{
${ }^{35}$ David Rosenboom, "Music Notation and the Search for Extra-Terrestrial Intelligence,” Leonardo 26, no. 4 (1993): 273-74.

${ }^{36}$ Willard Van De Bogart, "Extraterrestrial Contact: Creating Xenolinguistic Sonic Messages for Extraterrestrial Communication - Ether Ship Electronic Music Orchestrations in the Anza-Borrego Desert," Technoetic Arts 12, no. 1 (2014): 47-73, doi:10.1386/tear.12.1.47_1.

37 Tim Summers, "Star Trek and the Musical Depiction of the Alien Other," Music, Sound \& The Moving Image 7, no. 1 (2013): 19-52.
} 
contrast to that of the human characters in instrumentation, timbre, and intervallic relationships between pitches.

\section{Conclusion and Chapter Outline}

Although there are large bodies of scholarship that address postcolonial studies, music, and outer space or extraterrestrials, no scholar has attempted to merge the three. Though Tim Summers' aims are similar to my own in his research on otherness in the alien characters of the Stark Trek franchise, I intend to go beyond his work to explore ideas even more central to postcolonial theory, such as the crucial exchanges, musical and otherwise, that occur between colonizer and colonized (in this case, between human and extraterrestrial); the frequent disconnect between identity and representation (in the Othered extraterrestrial population); and how the intersections of race, gender, and class in (extraterrestrial) music of the Other can reflect past and current terrestrial issues. Additionally, my thesis will go beyond film music studies to address these issues through depictions of extraterrestrials not only in science-fiction movie scores, but also in Western art music and popular music. By studying these musical depictions of space and space beings, my research will explore crucial ethical questions in an age when space colonization has become a reality.

In the first chapter of this thesis, "Colonial Encounters, Alien Languages, and the Exotic Music of Denis Villeneuve's Arrival," I examine the 2016 science-fiction film starring Amy Adams and Jeremy Renner, which plays on familiar science-fiction tropes concerning threats of warfare, domination, and colonization by non-human intelligent life. An adaptation of Ted Chiang's short story, "Story of Your Life" (1998), the film considers the possible dangers of miscommunication between humans and extraterrestrials, with artistic visuals and a musical 
score that portray the visiting cosmic beings as inhuman, threatening Others. Specifically, I explore the ways that Jóhann Jóhannson's experimental score for Arrival and Max Richter's sorrowful musical work "On the Nature of Daylight" (which frames the entire film) reinforce colonial narratives within the film. Richter's emotional string piece represents the human experience through its recognizably tonal musical language and familiar Western timbres, heard only in scenes involving the film's protagonist, Louise (played by Amy Adams), and her family. Alternatively, Jóhannsson’s ambient score blends electronically-distorted human voices and nonWestern elements to create a startling musical alterity that portrays the alien Others as frightening and strange. Drawing upon insights from Loomba, Bloechl, and other aforementioned scholars of postcolonial studies, I explore the similarities between historical, cultural, and musical representations of non-Western Others and Arrival's extraterrestrial Others, suggesting that the juxtaposition of Jóhannsson and Richter's contrasting musical idioms creates a drastic auditory difference that echoes the past while also exemplifying prevailing colonialist ideologies in the late Space Age.

In chapter two, “"Reach[ing] Out from Earth': Colonialist Ideologies, Sounds from Space, and Terry Riley's Sun Rings,' I explore the composer's ten-movement work for string quartet, chorus, and space sounds, commissioned by the NASA Art Program in 2001 and premiered by the Kronos Quartet in 2002. Each movement constitutes its own "spacescape," often adapting sounds and techniques inspired by Hindustani classical music and music of other indigenous cultures. As longtime collaborators, both Riley and the Kronos Quartet have been heavily influenced by non-Western music, facing criticism for their engagement with, and appropriation of, musical idioms evocative of other cultures. I argue that this borrowing of nonWestern musical idioms is inextricably linked with Riley's persona as a New Age spiritualist, 
which also problematically borrows from a variety of philosophies and world religions. Thus, in this chapter, I examine Riley's Sun Rings from a postcolonial perspective, exploring the composer's problematic appropriation of the philosophies and music of other cultures to represent outer space and the possibility of intelligent life elsewhere in the galaxy. The combination of non-Western elements and space audio in his exotic spacescapes is distinctly colonial, evoking colonialism of the past through Eastern musical idioms while also suggesting space as the new frontier through futuristic recorded sounds from space. Drawing once again upon the postcolonial theories of Loomba, Forsdick, and others, I demonstrate that Riley's incorporation of non-Western musical techniques is representative of the composer's own biases about what constitutes sonic alterity, thereby perpetuating an age-old problematic ideology of the non-Western Other.

My final case study in chapter three, "Hearing Space Through an Astronaut's Ears: Colonial Themes and Masculinity in Chris Hadfield's "Songs About Space” Spotify Playlist," draws upon the social media persona of former International Space Station Commander Chris Hadfield, who was the first human to record songs and a music video in space. His Spotify playlist "Songs About Space" is a compilation of Western music, mostly popular songs, which he purports remind him of his experiences on the International Space Station. Yet the playlist is compiled almost exclusively of male artists, musicians, and producers, and in this representation Hadfield grants the agency and power of spaceflight to the male gender alone. The themes contained within the music on the playlist—masculinity, heroism, loneliness, and heterosexual desire - also echo the themes contained within diaries and letters of male colonists during earlier terrestrial conquests, suggesting that colonial history has already begun to repeat itself in the minds and experiences of contemporary astronauts who settle (for limited durations) in space. 
After a close reading of the playlist's narrative implications in its original order and on shuffle, I close this chapter by proposing a space topos which attempts to assemble the textures, timbres, and themes of Hadfield's playlist into a succinct definition that represents the patriarchal West's musical understanding of space.

In the thesis' conclusion, I frame my larger ideas about musical representations of the extraterrestrial Other in the context of contemporary politics in the United States. Particularly, I am concerned with President Donald Trump's similar Othering of Syrian refugees, asylumseekers at the southern border, and other non-white, non-Christian, or non-American Others. I draw upon Hannah Arendt's The Origins of Totalitarianism to suggest that the Trump administration's use of propaganda and terror in some ways resembles the harmful musical depictions of the extraterrestrial Other found within the musical score to Arrival, Terry Riley's Sun Rings, and Hadfield's "Songs About Space” Spotify playlist. These representations all have in common the tendency to treat Others as monolithic, frightening, inferior, and / or dangerous, and most of all they are misrepresentations that, through colonialism, lead to socioeconomic and political strife, genocide, and environmental destruction.

Ultimately, as we approach a reality that could one day soon resemble science-fiction, this thesis advocates for a more culturally- and socially-conscious approach to space exploration. By drawing upon postcolonial studies and the musical case studies contained within my chapters, I hope to demonstrate the need for an approach to a cosmic future that considers our past wrongs to indigenous groups to prevent these atrocities from repeating themselves in other spaces and on other planets. More broadly, I hope that my case studies will also illustrate some of the problematic ways in which the West continues to represent and treat non-European-descended 
people here on Earth, and to draw attention to the negative consequences of appropriation, misrepresentation, and exploitation of these terrestrial human groups. 


\section{Colonial Encounters, Alien Languages, and the Exotic Music of Denis Villeneuve's Arrival}

"How do we communicate with an intelligent species with who[m] we have no common point of reference?"38 Though perhaps this profound question could be asked retrospectively, in reference to numerous colonial encounters throughout history—encounters between humans that ended needlessly in violence and domination over indigenous peoples rather than in actual communication and respectful cohabitation - the question instead was a rhetorical one asked by Icelandic composer Jóhann Jóhannsson as he described his compositional process for the musical score to Arrival. The 2016 science-fiction film, directed by Denis Villeneuve, was based on the novella "Story of Your Life" by Ted Chiang and adapted to the big screen by screenwriter Eric Heisserer. As indicated by Jóhannsson, communication is a central theme in the film, which takes place when twelve extraterrestrial pods land mysteriously around the Earth.

Linguist Louise Banks, played by Amy Adams, and physicist Ian Donnelley, played by Jeremey Renner, are hired by the U.S. Army to discover the aliens' purpose on Earth. As Louise studies the extraterrestrials' language and attempts to teach them her own in the hopes of eventually discovering their reason for visiting, she has unexplainable visions of herself raising a little girl named Hannah who is diagnosed at a young age with a fatal and incurable illness. Meanwhile, militaries across the world, especially China, are distrustful of the aliens that have also landed in their own countries. When Louise is forced to ask about the aliens' purpose before either party can fully understand one another, tensions amongst the militaries escalate when the aliens' answer is misinterpreted as "use weapon." The Chinese military and others respond by giving the extraterrestrials twenty-four hours to leave Earth or else face an attack, yet Louise is determined to prevent warfare and returns to the alien vessel to clarify their message. She

\footnotetext{
38 Jacob Hall, "Interview: Arrival Composer Jóhann Jóhannsson on How You Score First Contact," Slash Film, November 11, 2016, https://www.slashfilm.com/johann-johannsson-arrival-music/.
} 
discovers that the "weapon" is actually a gift—-the gift of the aliens' non-linear language, which allows one who has mastered it to comprehend time non-linearly. Louise realizes that the girl from her visions is her unborn daughter, and that the alien language allowed Louise to see her own future. As the Chinese military prepares to carry out an attack the pods, Louise has another vision of herself a year and a half into the future, wherein she meets the General Shang of China who thanks her for convincing him of the aliens' peaceful purpose. In the present, Louise risks her life to steal a satellite phone and contact the general, relaying his wife's dying words which Louise learned during her vision. With the general's mind changed, the Chinese military immediately backs down and the other hostile countries follow suit. The aliens take off peacefully into space as Louise reflects on the experience with Ian, with whom she soon makes a conscious decision to have a child despite knowing that her visions of Hannah will come true and that Hannah will die young and Louise will be left heart-broken.

Because communication and language are so central to the plot of Arrival, Jóhannsson says that he was "really motivated by the script and the story" to create the bulk of the score by recording and experimenting with human voices. ${ }^{39}$ "There is a lot of vocal music in the score, both choir and solo singers. I worked with a chamber choir, Theater of Voices, more experimental vocalists, people who are really doing very strange things with their voices. You know, really extended vocal techniques. Throat singing and harmonic singing. They really treat the voice as an instrument in a textural way." 40 The words "strange" and "experimental" are

\footnotetext{
39 Ibid.

${ }^{40}$ Ibid. For more information about the composer's compositional process, see Sharon O'Connell, “Arrival Composer Jóhann Jóhannsson: 'People are Hungry for New Sounds, "’ The Guardian, November 26, 2016, https://www.theguardian.com/music/2016/nov/26/arrival-johann-johannsson-soundtrack-oscar-nominated; Steve 'Frosty' Weintraub, “Composer Jóhann Jóhannsson on Arrival, Preparing to Score Blade Runner 2049, and More," Collider, October 26, 2016, http://collider.com/johann-johannsson-arrival-blade-runner-2-interview/\#inspiration; Hrishikesh Hirway, "Song Exploder: Jóhann Jóhannsson on the Secrets of Arrival's Score," Vulture, November 17, 2016, http://www.vulture.com/2016/11/arrival-score-johann-johannsson-song-exploder.html; and Dallas Taylor, "Loop Groups," Twenty Thousand Hertz, podcast audio, 2018, https://www.20k.org/episodes/loopgroups.
} 
perhaps accurate descriptors of Jóhannsson's composition for Arrival, at least in comparison to the motivically-structured scores of more well-known film composers like John Williams. ${ }^{41}$ Jóhannsson's futuristic methods that include using electronic sounds and looping techniques are a marked contrast from that of the romantic orchestral film score often heard in Hollywood, and this innovation is especially appropriate for a film like Arrival. The ambient music that Jóhannsson creates from human voices and other instruments transports audiences into an unearthly soundscape that emphasizes the striking alterity of the extraterrestrials and their presence on Earth. As with the bizarre sight of the aliens' pod vessels, their enormous tentacled bodies, and the circular appearance of their curious written language, Jóhannsson's score complements these uncanny visuals with an auditory exoticism that evokes both wonder and apprehension of the alien beings.

While Jóhannsson's musical compositions make up the bulk of Arrival's score, the emotional string piece "On the Nature of Daylight" by British composer Max Richter is also featured in the opening and closing scenes of the film, which show Louise and Hannah in a montage of memories that vary from heart-warming, as the two play together in the yard, to heart-breaking, as a crying Louise begs her lifeless daughter to "come back to [her]." "On the Nature of Daylight" was originally composed for Richter's 2004 album The Blue Notebooks, which he wrote as "a protest album about [the military intervention in] Iraq, a meditation on violence." ${ }^{42}$ Both in the context of war and also in Louise's bittersweet time with Hannah,

\footnotetext{
${ }^{41}$ Jóhannsson composed music for several films including Prisoners (2013) and Sicario (2015), both of which were also directed by Villeneuve, as well as The Theory of Everything (2014, directed by James Marsh) which won the Golden Globe Award for Best Original Score. The experimental sound for which he is known was born from his 2002 solo album Englabörn and continued to evolve throughout other solo albums, collaborations, and television and film scores until Jóhannsson's untimely and unexpected death in February 2018.

${ }^{42}$ Max Richter, "Millions of Us Knew the Iraq War Would Be a Catastrophe. Why Didn't Tony Blair?" The Guardian, July 8, 2016, https://www.theguardian.com/commentisfree/2016/jul/08/iraq-war-tony-blair-creativitychilcot-inquiry. In addition to The Blue Notebooks, Richter has released several other albums of contemporary experimental art music including his 2002 Memoryhouse, a 2010 recomposed version of Vivaldi's The Four
} 
Richter's string suite achieves a somber and affective beauty by introducing one evocative melody and gradually building others upon it, culminating in a gorgeous layered wash of sound that is both texturally warm and emotionally sorrowful. While Richter's musical idiom is contemporary, his orchestral instrumentation and tonal language is much more familiar to the average listener than Jóhannsson's ambient score that, to some, might at times be better described as "sounds" rather than "music" due to its deviant instrumentation, structure, and compositional methods. Yet despite their differences, both composers' compositions work well in the grand scheme of Arrival: while Richter's sentimental string piece in the opening and closing of the film accentuates the strong feelings of love and grief that Louise has for her daughter Hannah, Jóhannsson's ethereal musical effects throughout the rest of the film heighten the exoticism of Louise's sublime experience with the alien visitors.

The musical score to Arrival, especially in its juxtaposition of Richter's and Jóhannsson's distinct styles, offers an exemplary case study of the way that film music can, whether intentionally or unintentionally, further emphasize colonialist themes in a plot. The more familiar musical idiom used by Richter, recognizably tonal and played by string instruments, is used to depict the lives of Louise and Hannah. Despite Hannah's tragic undoing, their scenes together represent a familiar human life — one mixed with laughter, tears, joy, love, and loss. Essentially, Richter's music represents the "normal." On the other hand, Jóhannsson's music, experimental and perhaps utterly foreign to the ears of many listeners in its ambient texture and distortion of human voices, accentuates the comparative "abnormality" of the extraterrestrials. Indeed, the use of exotic music to represent an Other in films is not a new phenomenon; for instance, Tim Summers has demonstrated musical difference in representations of non-human characters in the

Seasons, and most recently his 2017 Three Worlds: Music from Woolf Works, the score of the ballet Woolf Works which was inspired by the writings of Virginia Woolf. 
Star Trek franchise through certain instrumentations, timbres, and intervallic pitch relationships, while Claudia Gorbman has similarly drawn attention to the clichéd tropes of percussive tomtom rhythms and exotic modal motifs to represent Native American characters in western film scores. ${ }^{43}$ In Arrival, Jóhannsson achieves his own musical exoticism by using ambient effects like drones and layered electronic loops that paint the extraterrestrials as not only strange and foreign, but also as frightening and dangerous. Images of threatening Others hearken back to Western narratives about Native Americans, Indians, Africans, and other indigenous groups of people whose very existence appeared intimidating enough to justify domination and exploitation in the eyes of Western colonists. One need not look further than Pocahontas' biography or James Fenimore Cooper's 1826 historical novel The Last of the Mohicans and its many adaptations to understand the prevalence of this trope, which is recorded not from the perspective of the colonized but rather always the perspective of the Western colonizer. The colonizers have thereby asserted dominance not only in the violence and oppression of the Natives but also in the writing of history from a biased Western perspective. In Arrival, the humans' lack of ability to communicate with the extraterrestrials recreates language and cultural barriers similar to those encountered in the New World. An inability to understand (and thus an inability to control) the aliens eventually mounts to tensions that, without Louise's intervention, could have become genocide, and Jóhannsson's unearthly musical techniques exacerbate this tension. The unfamiliar and at times unsettling sounds associated with the extraterrestrials in the film accentuate the plot's underlying colonialist themes: fear of the unknown, miscommunication across languages and cultures, and resorting to violence as a means of control.

\footnotetext{
${ }^{43}$ See Tim Summers, "Star Trek and the Musical Depiction of the Alien Other," Music, Sound \& The Moving Image 7, no. 1 (2013): 19-52; and Claudia Gorbman, "Scoring the Indian: Music in the Liberal Western," in Western Music and Its Others: Difference, Representation, and Appropriation in Music, ed. Georgina Born and David Hesmondhalgh, 234-253 (Berkeley: University of California Press: 2000), 235.
} 


\section{Jóhannsson's Musical Score to Arrival}

The first that we hear of Jóhannsson's alien soundscape occurs when the extraterrestrials land on Earth. As linguistics professor Louise and her university students watch the developments on the news, a low and unceasing drone begins, likely serving as a sonic representation of Louise's unshakeable sense of fear, uncertainty, and curiosity about the alien pods. This ambient drone, used in several instances throughout the film, is not unlike an Indian tanpura in sound and function. ${ }^{44}$ Like the long-necked string instrument from Asia, Jóhannsson's drone creates a continuous ambience onto which he builds other musical ideas in a higher register that are often hypnotic and repetitive. For instance, the night that the aliens land, Louise tosses and turns in her bed while the drone and a higher-pitched ethereal wavelike effect are heard. The waves, crescendoing and decrescendoing minor chords played by strings and possibly voices as well, wear on like Louise's insomnia, her mind likely spinning at the thought of the alien visitors. The low drone has a slightly foreboding effect, its constant presence like a nagging feeling of danger. Yet the evocation of the Indian tanpura also situates the extraterrestrials more firmly in a colonial context, bringing to mind not only exotic depictions of the Middle East but also India's colonization by Britain and other European settlers. Jóhannsson's drone during the alien arrival scene could also be serving as foreshadowing at the tensions to come and the military's response to the extraterrestrials which echo Europe's exertion of power over India.

After Louise is hired by the military for her linguistics expertise, Louise, Ian, and other members of the team helicopter to the site of the alien pod that landed in Montana. The ethereal music in this scene reflects the awe-inspiring sight of the strange, towering pod situated in a

\footnotetext{
44 The tanpura is also known as the tambura (sometimes seen as tānpūrā, or tāmbūrā). Ruth M. Stone, ed., The World's Music: General Perspectives and Reference Tools, Garland Encyclopedia of World Music 10 (New York: Routledge, 2002), 307. https://search.alexanderstreet.com/view/work/bibliographic_entity\%7Creference_article\%7C1000223919.
} 
foggy valley framed by mountains. Here, the drone is accompanied by a slow, uneven pattern of strange wavering timbres that alternate between three different pitches each a minor third apart. Not only is the minor mode often associated in the West with negative emotions like fear or sadness, but the minor third is also enharmonically equivalent to the augmented second, an interval frequently associated with non-Western music but adapted by Western composers to convey exoticism. Underneath these evocative minor thirds, quieter effects contribute to the eeriness of this alien soundscape, like sinister string tremolos and the metallic pulsing of a cymbal. Underscoring it all is the persistent beating of the helicopter's blades as the Louise and the rest of the team fly towards the bizarre sight. The result is equal parts unnerving, thrilling, and terrifying, likely reflecting Louise's own feelings at such a disconcerting sight while simultaneously creating an exotic atmosphere that sonically communicates to the audience that these visitors are indeed alien in every sense of the word.

\section{Figure $1 .^{45}$}

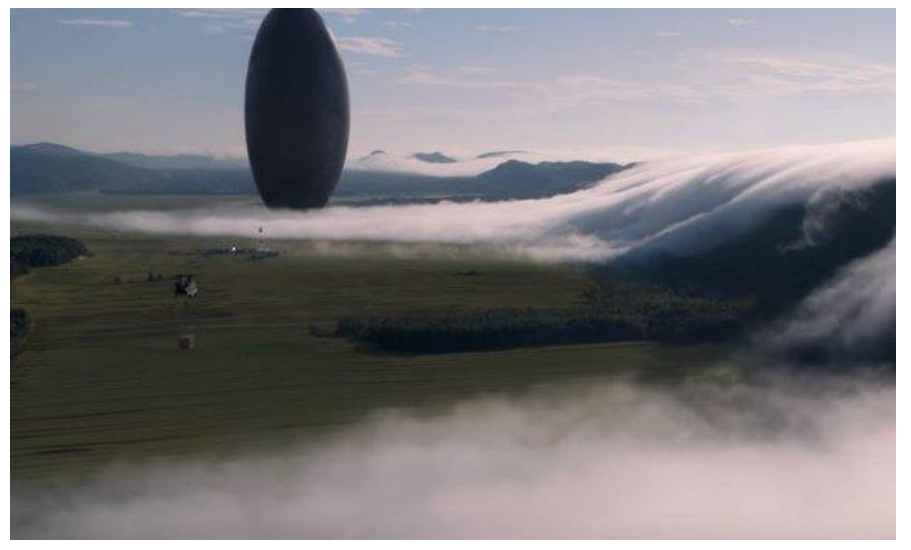

\footnotetext{
${ }^{45}$ Figure 1: A still from the Arrival scene in which Louise and Ian first see the alien pod from their helicopter.
} 


\section{Example 1. ${ }^{46}$}

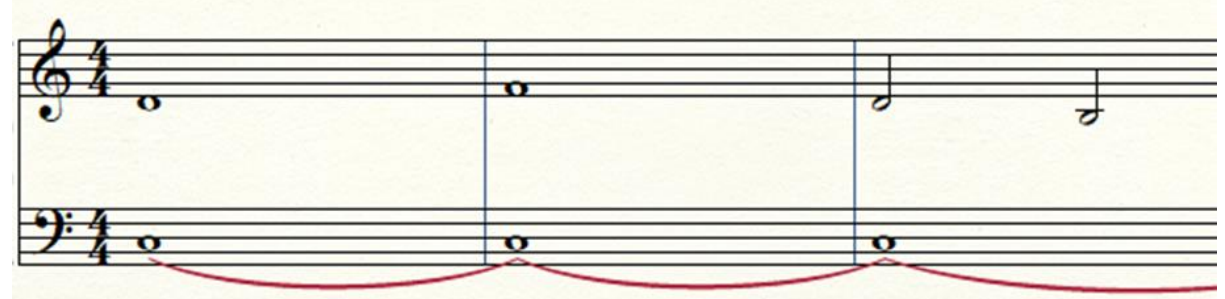

As Louise and the others make their way into the pod in their first attempt to make contact, the music continues to reflect a feeling of uncertainty. A dramatic pitch-bending effect in a low register emphasizes the loss of balance that the team feels when, in the pod's depths, the gravitational pull changes drastically, giving the characters the impression that they are walking upwards at a ninety-degree angle. This disorienting Mickey Mousing effect is followed by a heartbeat-like rhythmic pulsing in low plucked strings, quiet yet unrelenting, exacerbating the suspense as Louise and the others apprehensively make their way further into the pod. As the two massive extraterrestrials suddenly appear, looming several stories above the humans, a startlingly loud note rises from a dramatic glissando, sonically reflecting the sublime sight of the enormous beings. The note rises by a half step and then falls by yet another augmented second before fading into an echo and disappearing into nothingness, only to happen again seconds later, familiar now but just as startling in its contrast with the empty silence before it. These alarming musical statements, one for each of the two extraterrestrials in the pod, are not only exotic in their intervallic relationships and ornamentation but also in their unusual timbres, likely created from manipulated vocal recordings. This first encounter with the extraterrestrials sets a precedent in Jóhannsson's score by blending musical alterity with fear, which in this case is created by the contrast of suspenseful quiet rhythms followed by legato pitches at shockingly loud volume. This

\footnotetext{
${ }^{46}$ Example 1: A transcription of the melody and drone from the track "Arrival" on Jóhannsson's soundtrack for Arrival, the same music that is heard in the scene from Figure 1.
} 
intermingling of the exotic and the frightening suggests that that the alien visitors themselves should be feared, despite the fact that the extraterrestrials are as peaceful and docile as any being could be. Yet like the Native Americans to settlers of the New World or the indigenous occupants to settlers of India, the extraterrestrials are unfamiliar and therefore inherently threatening to the West's self-appointed power.

When Louise attempts to communicate by writing on a handheld dry erase board, one extraterrestrial in response produces a mysterious ink-like substance from a tentacled limb to create a symbol of its own in mid-air. Louise and the other humans are visibly excited by this breakthrough in communication, and Jóhannsson's score moves quickly to emphasize their exhilaration. Beginning with a woman's voice, pleasant and wordless, followed by another voice a major third below, Jóhannsson layers consonant sounds that suggest hope for the humanextraterrestrial relationship. The major interval that opens the sequence is a marked contrast to the minor third / augmented second so prevalent in the earlier musical statements. Along with the voices, which alternate between a variety of different sounds like humming and singing the syllable "la," Jóhannsson adds a busy uneven pulsing in the strings that crescendos and decrescendos like a wave, as well as a low note in the bass that is reminiscent of the drone, though now it too comes and goes. All of these layers are out of time with one another, not quite lining up rhythmically. The constantly changing layers of human voices and other sounds on top of one another create an atmosphere of a crowded room, an auditory manifestation of the language barrier that has begun to break down between the two species. Yet at the same time, the wordless voices also draw attention to both parties' continued inability to fully understand one another. The voices convey no meaning; rather, they merely serve as unintelligible sound. In some ways, this inability to communicate is likely reminiscent of Western colonists' ideas about 
the language of native people. For instance, Olivia A. Bloechl points out that Captain John Smith in his writings about the New World described Native American song as "hellish notes and screeches," concluding based on their strange language and music that they must "worship the devill. ${ }^{47}$ His rash assumption about the Native Americans demonstrates how easy it could be for humans like those in Arrival to drastically misinterpret extraterrestrial communications. The wordless voices in Jóhannsson's composition evoke not only this inability to understand but also this same assumption that "different" and "foreign" must be synonymous with "bad."

The essence of the colonialist ideals behind the military's actions in the film are articulated outright in a short exchange between Louise and one of the commanders at the army base. After China, Russia, and other countries make the controversial decision to give the extraterrestrials a twenty-four hour ultimatum, the commander says to Louise, "We have to consider the idea that our visitors are prodding us to fight among ourselves until only one faction prevails." Louise, taken aback, responds, "There's no evidence of that." The commander then replies, "Sure there is - just grab a history book. The British with India, the Germans with Rwanda, they've even got a name for it in Hungary. Yeah. We're a world with no single leader. It's impossible to deal with just one of us. And with the word 'weapon' now..." The irony of the commander's historical examples is, of course, that the West itself was and is the dangerous aggressor, and the commander is merely projecting the West's atrocious colonial tendencies onto the peaceful alien beings. Rather than seeking to understand the strange species, the majority of

\footnotetext{
${ }^{47}$ Olivia A. Bloechl, Native American Song at the Frontiers of Early Modern Music (New York: Cambridge University Press, 2008), 52. She quotes Captain Smith directly from John Smith, The Complete Works of Captain John Smith (1580-1631), ed. Philip L Barbour, 3 vols (Chapel Hill, NC: University of North Carolina Press, 1986). Bloechl argues that Smith, a Protestant, jumped to these conclusions based on his knowledge of Catholic rituals, like praying the rosary for penance. Smith's writings indicate that he viewed both Catholic traditions and the Native Americans' worship rituals as superstitious idolatry.
} 
the humans in the film respond with this same fear and aggression, adapting a "kill or be killed" mentality.

In juxtaposition with this colonial violence and Jóhannsson's exotic score, Louise's vision of the future in which she meets the Chinese General at a ritzy ball has instead a familiar, even serene soundscape. As Louise and the General talk, a string ensemble performs the fourth movement, Larghetto, of Serenade for Strings in E Major, Op. 22 by Antonín Dvoř́k. ${ }^{48}$ The excerpt of this movement in the film is slow and elegant. A violin plays the legato melody, its pleasing sonorities and recognizably Western timbres a dramatic change from Jóhannsson's alien music. Dvořák's graceful string piece is an appropriate choice for the extravagant event; guests sip cocktails wearing floor-length gowns and suits, the epitome of high-class. It is hard to imagine in this sophisticated atmosphere that these same humans were almost responsible for the genocide of a peaceful species. This dignified portrayal of the humans through Dvorrák's high-art music makes even more apparent the comparative exoticism and dangerous uncertainty of the extraterrestrials' portrayal through the alien sound world created by Jóhannsson.

During the vision, as the General informs Louise that she had previously called him on his personal number and relayed his wife's dying words, stating that Louise's actions were the sole reason why he did not carry out his attack on the extraterrestrials, Jóhannsson's foreign soundscape reappears. Between flashes of the main setting of the film — the alien visit — and flashes of Louise's future meeting with the General, an ominous drone is heard once again, punctuated by a single legato note in a lower register that repeats insistently. On top of this foundation, Jóhannsson begins to stack other musical effects that sonically intensify the rising action as Louise risks her life to steal the satellite phone to call the General. Slow downward

\footnotetext{
${ }^{48}$ This movement is performed by the Berlin Chamber Players and conducted by Benoît Fromanger.
} 
glissandos in a low register contribute to the anxiety of the scene, and as Louise procures the phone and makes the call, the strings begin to bow a barrage of rhythmically offset notes that increase in pitch, sonically building to a climax that reflects the building of action. A higherpitched tone begins to pulse at an increasingly loud volume as a flash of the future depicts the General relaying to Louise his late wife's message in Mandarin. As the music reaches its loudest and then fades, future Louise stares shocked at the General as present Louise finishes the call and surrenders the satellite phone at gunpoint.

"In war there are no winners, only widows." 49 Though not subtitled in the film, this is the translation of the words that General Shang shares with Louise-his wife's dying words. Yet scholars of postcolonial studies would likely disagree with this sentiment. Though war and conquest do indeed result in large amounts of death, there are winners, or at least there have been historically. The European "winners" of the past acquired not only land but granted themselves with the authority to control the colonists' culture, religious beliefs, literature, and languageessentially every aspect of the Natives' daily lives. Ania Loomba notes the way that colonialism led to a complete restructuring of learning, literature, and language by drawing upon preconceptions about the inferiority and savagery of non-Europeans to justify cultural and military domination after colonization. ${ }^{50}$ The 2016 film Arrival may have ended happily, avoiding what could have been a much more depressing yet all too familiar ending for the extraterrestrials, but the rest of the film's plot and its musical score articulate the still-prevalent colonialist ideals held in the West: us versus them. This mentality, the fear of and violent reaction toward the extraterrestrials in Arrival, mirrors not only historical colonialism but also

\footnotetext{
${ }^{49}$ Matt Patches, "The Mystery Line in Arrival, Revealed,” Thrillist, November 13, 2016, https://www.thrillist.com/entertainment/nation/arrival-chinese-line-ending.

50 Ania Loomba, Colonialism/Postcolonialism (New York: Routledge, 2015), 72-73.
} 
the United States' present day dealings with Syrian refugees and Mexican immigrants. The current administration insists that, in creating travel bans and strict immigration laws, we are defending our country (like the militaries in Arrival defended their planet), while the immigrants and refugees (like the extraterrestrials) are intruders from whom we must protect ourselves at all costs. However, while current politics suggest no end in sight to this discrimination of so-called outsiders, Louise's actions serve as the catalyst for peace in the 2016 film.

After Louise's words convince the General to call off his attack, all twelve alien pods take off into cloudy skies, leaving as peacefully as they arrived. The mysterious, quiet vessels move slowly, gently displacing clouds as they meander into the outer reaches of Earth's atmosphere and disappear. Their departure is the last we hear of Jóhannsson's exotic soundscape, which uses manipulated human voices in both high and low registers over a serene synthesized chord to create an eerie effect that sonically mirrors the awe-inspiring sight of the pods' rise to the heavens. In the lowest register, a legato note rises in a perfect fifth as the pods lift into the sky. The prominence of this open, consonant interval signals a drastic shift in Jóhannsson's soundscape; not only does it reflect the pods' physical motion as they take off into space, but it also reflects a return to order, both sonically and situationally. With the aliens gone, life on Earth goes on unthreatened by outsiders, unthreatened by curious tonalities, manipulated instrumentations, and foreign soundscapes. Their departure signals a return to the normal, demonstrated by Richter's aching "On the Nature of Daylight" with its familiar string textures and tonal language. The film's emotional close, a montage of scenes depicting Louise, Ian, Hannah and their interwoven destinies, reiterates through music the normalcy of the human experience. Though perhaps heart-breaking at times, the scenes and the audio in the final minutes 
of the film are much more familiar depictions of life as movie-goers know it, compared to the bizarre sights and sounds of the earlier alien encounter scenes.

\section{Musical Othering in Science-Fiction More Broadly}

While Jóhannsson's score might be innovative in its sound, functionally it follows in the footsteps of the longstanding science-fiction film score tradition that musically perpetuates the colonial mentality of alien encounters. For instance, Bernard Herrmann's score for Robert Wise's 1951 science-fiction film The Day the Earth Stood Still makes heavy use of the Theremin, a spooky electronic instrument that creates sound by the manipulation of two antennae, one that controls amplitude and the other frequency. ${ }^{51}$ Hermann's musical language in the film score is reminiscent of horror film music: like Jóhannsson, Hermann exploits the creepy potential of the low register by frequently using tubas and other low brass to sometimes represent the alien characters as fearsome and menacing. For instance, at the first appearance of the alien Klaatu's metal robot, a sinister legato low brass idea accompanied by a mid-register wavering Theremin plays as the robot makes his way off the spaceship. The result is an ominous sound that has since become synonymous with danger in science-fiction films. This scary depiction is appropriate for the scene, however - in retaliation to the unnecessary violence that the military

\footnotetext{
${ }^{51}$ Bernard Herrmann is known especially for his work with Alfred Hitchcock on films like Psycho (1960) and Vertigo (1958), though he also composed for other directors on films like Citizen Kane (1941) and The Day the Earth Stood Still. For more information about the Theremin in science fiction films, see James Wierzbicki, "Weird Vibrations: How the Theremin Gave Musical Voice to Hollywood's Extraterrestrial 'Others," Journal of Popular Film and Television 30, no. 3 (2002): 125-135. For more information about Herrmann's score for The Day the Earth Stood Still, see Anthony Bushard, "Waging the Peace: Bernard Herrmann and The Day the Earth Stood Still," College Music Symposium 49/50 (2009/2010): 314-326; Ross Care, "Klaatu Barada Nikto!: The Day the Earth Stood Still," Film Score Monthly 16, no. 6 (2011): 5; E. Todd Fiegel, "Bernard Herrmann as Musical Colorist: A Musicodramatic Analysis of His Score for The Day the Earth Stood Still," Journal of Film Music 1, no. 2/3 (2003): 185-215; William H. Rosar, "The Penumbra of Wagner's Ombra in Two Science Fiction Films from 1951: The Thing from Another World and The Day the Earth Stood Still," in Wagner and Cinema, ed. Jeongwon Joe and Sander L. Gilman, 152-164 (Bloomington: Indiana University Press, 2010); Wierzbicki, "Weird Vibrations," $125-$ 135.
} 
exhibited towards Klaatu, the robot disembarks from the vessel to shoot lasers from his eyes that destroy all the military's guns and tanks as the civilian crowd runs away, terrified and screaming. Yet although the robot and Klaatu visit Earth not for a sinister reason but on a peace-keeping mission, Hermann's score, like Jóhannsson's score for Arrival, musically depicts the extraterrestrial Others as dangerous. If one agrees with Claudia Gorbman's thesis about film scores sometimes functioning as "unheard melodies"- a manipulation device of sorts_Hermann's music is particularly effective not only because it sonically reinforces the plot but also because it reinforces a subconscious fear of the alien Other through music that manipulates an audience's "sensory background." 52

A similar idiom is used in the horror-inspired scenes of Steven Spielberg's 1977 Close Encounters of the Third Kind. ${ }^{53}$ For instance, when the alien visitors abduct the toddler Barry, John Williams' score also makes use of a foreboding low register. The scene begins as the extraterrestrial vessel makes its way towards the house, darkening the sky like an ominous approaching storm. Accompanying this terrifying image is a jarring dissonance created by low brass instruments one half step apart from one another. High-pitched violins glissando upwards grotesquely and create dissonant tremolo effects as the aliens attempt to get into the house. Juxtaposed with the comical low brass theme as the vacuum comes to life and chases Barry's horrified mother, Williams' score in this scene creates fear through dissonant and menacing effects, musically extreme registers, and the evocation of musical humor during a decidedly

\footnotetext{
${ }^{52}$ Claudia Gorbman, Unheard Melodies: Narrative Film Music (Bloomington: Indiana University Press, 1987): 12.

${ }^{53}$ John Williams is known for his iconic musical scores to films like those in the Star Wars franchise (1977, 1980, 1983, 1999, 2002, 2005, 2015, 2017, 2018, 2019), Jaws (1975), E.T. the Extra-Terrestrial (1982), and the first three Harry Potter films $(2001,2002,2004)$. His approach is neoromantic, using Wagnerian-like leitmotivs to represent specific characters, situations, and ideas. For more about Williams' score to Close Encounters of the Third Kind, see Neil Lerner, "Nostalgia, Masculinist Discourse, and Authoritarianism in John Williams' Scores for Star Wars and Close Encounters of the Third Kind," in Off the Planet: Music, Sound, and Science Fiction Cinema, ed. Philip Hayward, 96-109 (London: John Libbey, 2004); and Tom Schneller, "Sweet Fulfillment: Allusion and Teleological Genesis in John Williams' Close Encounters of the Third Kind," The Musical Quarterly 97, no. 1 (2014): 98-131.
} 
serious horror scene. Though these space visitors, too, turn out to be peaceful tourists, Williams' terror-evoking musical depiction exacerbates the audience's fear of the intruders.

Like Arrival, modern day films generally follow this same tactical formula. For instance, in the 2011 J.J. Abrams film Super 8, the only theme in Michael Giacchino's score that utilizes minor mode low brass is the alien theme ${ }^{54}$ While the other themes in the film are used to represent the humans and their relationships, the alien theme is unique not only in timbre and register but also in its function: while the other themes in Giacchino's score evolve and intermingle in an almost Wagnerian compositional strategy, the alien theme remains static and ominous even after the extraterrestrial character is humanized in a plot twist that reveals that the creature has been tortured by the U.S. government for years and simply wants to go back to its home planet. ${ }^{55}$ This failure to humanize the alien Other through unchanging sinister music even after the imagined danger has passed is reminiscent of Gorbman's same observations about composers of western films, whose slow humanization of the Native characters likewise did not always reflect changing narratives. ${ }^{56}$

\footnotetext{
${ }^{54}$ Michael Giacchino is well-known for his beloved compositions in Pixar animated films like Ratatouille (2007), Up (2009), and Inside Out (2015). He and Abrams have also worked together numerous times on projects such as the television series Lost (2004-2010) and the recent Star Trek film franchise reboots (2009, 2013, 2016). Giacchino's compositional style is leitmotivic and known for its ability to "say" much with very little musical complexity. For instance, Michael Emerson, an actor in Lost, has said of Giacchino's musical writing, "I feel so often that films are overscored, or they're scored in a bright-major-key, full-symphonic kind of way. Michael is the antidote. I love the minimalism of his work [...]. [...] I love how subliminal it feels. Sometimes, I'm only barely aware that there is musical accompaniment. It's as if the music is in my head and not in the TV." See Alex Ross, “The Spooky Fill," The New Yorker 86, no. 13 (2010): 60-67.

${ }^{55}$ According to David Kay, the other musical themes in the film include a joyous love theme and a heartfelt family theme that eventually come together in an emotional statement about friends becoming family, as well as a hostile military theme that reflects the on-screen action during scenes that involve the antagonistic U.S. government. These three themes make use of woodwinds and strings (and the military theme employs high brass), but the unchanging alien theme is the only one that uses low brass. The motive that Giacchino uses for the alien is slow, legato, and sinister, much like the low brass ideas in Herrmann's and Williams' film scores. See David Kay, "Score Analysis: What Makes Super 8 Super?" Film Score Monthly 16, no. 8 (2011): 30.

${ }^{56}$ Gorbman, "Scoring the Indian," 241.
} 
Most recently, the 2018 film Annihilation, directed by Alex Garland, creates musical exoticism through electronic synthesizers. The film follows five women as they embark together on a research expedition into a curious electromagnetic field that has appeared on Earth, into which other researchers have voyaged and never returned. Because the majority of the film is focused on the human characters, composers Geoff Barrow and Ben Salisbury purposefully wanted to stay away from synthesizers in an attempt to emphasize what Salisbury calls "a human story," composing instead with instruments like acoustic guitar, waterphone, and strings. ${ }^{57}$ Yet at the climax of the film, the moment in which Lena, the last surviving researcher, encounters the birth of an extraterrestrial humanoid, the composing duo does incorporate a loud synthesizer, creating a jarring alterity entirely different from the soundscape heard earlier in the film. As the orchestral strings transform into a synthesizer riff that sounds as if meant for a dance club, Lena watches as a colorful nebulous cloud morphs before her eyes into a shiny, iridescent being. The low synthesizer becomes foreboding and is juxtaposed with uneven bouts of silence as Lena attempts to escape from the alien being, who mirrors her every movement, resulting in a horrifying dancelike duet across the room. ${ }^{58} \mathrm{~A}$ four-note alien motif then appears in the synthesizer as strings that have been looped backwards twinkle underneath. As the alien overpowers Lena, taking on her appearance and then killing her, eerie and dissonant human voices sing wordless chords as if in mourning. Perhaps not coincidentally, Barrow and Salisbury's compositional tools in creating musical alterity for the alien, namely their use of

\footnotetext{
${ }^{57}$ Andy Beta, “Annihilation: Geoff Barrow and Ben Salisbury Talk Its Haunting Score," Rolling Stone, March 14, 2018, https://www.rollingstone.com/music/music-features/annihilation-geoff-barrow-and-ben-salisbury-talk-itshaunting-score-197947/. The two composers also worked together on another science-fiction film by Garland entitled Ex Machina (2014), a film quite similar to the others explored in this study except that the exotic Other is an AI humanoid rather than an extraterrestrial.

${ }^{58}$ For a review that describes this dance and its meaning in detail, see Emily Yoshida, "Let's Talk About the Ending of Annihilation," Vulture, February 23, 2018, http://www.vulture.com/2018/02/annihilation-movie-endingexplained.html.
} 
electronics, innovative looping techniques, and eerie human voices, are reminiscent of Jóhannsson's tactics in his musical score for Arrival two years earlier. Both scores are deeply expressive and memorable in their separation of human and alien soundscapes, which is particularly effective in emphasizing their plots. As the twenty-first century goes on, perhaps this new type of futuristic soundscape will replace instruments like the Theremin and the vibraphone, which have so frequently been associated with space and aliens in twentieth century sciencefiction films.

\section{Conclusion}

Indeed, while its exotic score functions similarly to other film scores about extraterrestrial visitors and outer space, Jóhannsson's soundscape for Arrival is imaginative in comparison to older science-fiction film music. Rather than draw upon a horror film score idiom like Hermann and Williams, or rely on leitmotivs like Giacchino, Jóhannsson's experimental methods, unconventional orchestrations, and hypnotic musical ideas are much more musically progressive than they are functionally progressive. The brilliance of his composition aside, however, the soundscape that Jóhannsson has created for Arrival remains an ideal model to explore present-day colonial ideals represented in film scores. Especially juxtaposed with Richter's more recognizably Western idiom, the experimentalism of Jóhannsson's composition is itself a gesture of "exploration and discovery," as John Corbett would suggest. ${ }^{59}$ Indeed, Jóhannsson's score could be construed as its own type of musical colonialism. Jóhannsson's methods are exploratory, including recording and layering sound loops, playing them back at

\footnotetext{
${ }^{59}$ John Corbett, "Experimental Oriental: New Music and Other Others," in Western Music and Its Others: Difference, Representation, and Appropriation in Music, ed. Georgina Born and David Hesmondhalgh, 163-186 (Berkeley, University of California Press: 2000), 166.
} 
different speeds, and "sound-on-sound recording, recording over the sound while keeping the previous sound." ${ }^{60}$ Additionally, the score incorporates exotic sounds that at times mimic classical Indian instruments, and at other times electronically manipulates the human voice into an entirely unrecognizable timbre that suggests it is not human at all but something Other. Certainly, the score is a beautiful and inventive approach to an alien soundscape, though like other film scores before it, its appropriation of non-Western techniques and its evocation of fear through ominous music could be perceived as problematic in its perpetuation of exoticist musical thinking.

${ }^{60}$ Hirway, "Song Exploder." 


\section{"Reach[ing] Out from Earth": Colonialist Ideologies, Sounds from Space, and Terry Riley's Sun Rings}

A curious, high-pitched whistling reminiscent of a bird's chirping; a low crackling as if from the last remaining embers of a campfire; twinkling twitters of sound like a chorus of grasshoppers after dark, and soft, intermittent whistling like wind blowing through a forest's trees - these are the surprisingly Earthlike sounds one might encounter when listening to Professor Donald A. Gurnett's "Space Audio" project. ${ }^{61}$ Along with the University of Iowa's Department of Physics and Astronomy, Gurnett has been recording the sounds of outer space for over forty years thanks to special detection instruments attached to NASA spacecraft such as the Voyager probes and Cassini. ${ }^{62}$ And while these sounds might share a resemblance with those heard alongside the images described above, the audio is actually alien. The bird chirps are not made by winged creatures at all, but by lightning in Earth's magnetic field; the campfire crackles are instead the sounds of lightning deep within Saturn's atmosphere; and the grasshoppers and wind are, in reality, created by spinning electrons in Jupiter's ionosphere.

At the start of the new millennium, the NASA Art program approached the San Francisco-based string ensemble, the Kronos Quartet, with an idea for a new musical composition based on Gurnett's celestial recordings. "Commissioned by NASA and cocommissioned by the Hancher Auditorium, the University of Iowa, the National Endowment for the Arts, The Rockefeller Foundation, and other music-presenting organizations," the end result, Sun Rings, is an otherworldly multimedia presentation that blends the Kronos Quartet's strings

\footnotetext{
${ }^{61}$ Donald A. Gurnett and the University of Iowa, "Space Audio," Space-Audio.org, http://space-audio.org/. The names of the audio described is as follows: 1) "Earth Whistlers," from Selected Sounds in Space; 2) "the Sounds of Lightning at Saturn," in Archives section; 3) "Jupiter chorus," from Selected Sounds in Space.

62 Donald Savage, "NASA Music Out of this World," NASA.gov, https://www.nasa.gov/home/hqnews/2002/02207.txt.
} 
with choral singers, Gurnett's space sounds, numerous projected images from Earth and outer space, and a twinkling light show that gives its audience the illusion that they are indeed travelling into the far reaches of the universe. ${ }^{63}$ The breathtaking images from the NASA archive displayed behind the quartet, arranged by visual designer Willie Williams, include photographs taken by one of the Voyager crafts over the course of its interstellar travels. ${ }^{64}$ Additionally, composer Terry Riley's inventive musial score directly incorporates some of Gurnett's space recordings, and throughout, the string quartet mimics, responds to, and plays off of the recordings as if the human-musicians were having a musical conversation with entities from space.

In addition to composing Sun Rings, Riley is a much-celebrated American composer, known especially as creator of the famous 1964 piece In $C$. He is hailed as one of the pioneers of a musical style referred to as minimalism, and he was one of the first to work extensively with tape looping technology. ${ }^{65}$ Riley was profoundly influenced by music from a very young age, and thinks of the art as a spiritual experience:

"I remember listening to the radio as a little kid, listening to a popular song that I'll never forget, because it made me cry. [...] I think I was one or two years old, my mother said I just started crying when I heard it on the radio. I know music has this capacity to touch you very deeply and make you feel emotions... some people would say it comes from a past life, I'm not sure if I can say that with any degree of confidence, but I do know it awakens in us the musical experience that is very akin to the types of religious insights. It

\footnotetext{
${ }^{63}$ University of Iowa, “Sun Rings: Kronos Quartet,” Space-Audio.org, http://www-pw.physics.uiowa.edu/spaceaudio/sun-rings/.

${ }^{64}$ Savage, "NASA Music Out of this World," NASA.gov. For more about Willie Williams' background and role in the creation of Sun Rings, see Kronos Quartet, "Sun Rings," KronosQuartet.org.

${ }^{65}$ For more information about Riley's biography, his seminal In C, and his other works, see: Robert Carl, Terry Riley's In C, Studies in Musical Genesis, Structure and Interpretation (New York: Oxford University Press, 2009); Wim Mertens, American Minimal Music: La Monte Young, Terry Riley, Steve Reich, Philip Glass (London: Kahn \& Averill, 1983); Keith Potter, Four Musical Minimalists: La Monte Young, Terry Riley, Steve Reich, Philip Glass (Cambridge: Cambridge University Press, 2004); K. Robert Schwarz, "La Monte Young and Terry Riley," in Minimalists: 20th Century Composers (London: Phaidon, 1996), 15-49; Geoff Smith and Nicola Walker Smith, "Terry Riley," in New Voices: American Composers Talk About Their Music (Portland, OR: Amadeus Press, 1995); "Welcome to the Domain of Terry Riley," TerryRiley.net, http://terryriley.net/enter.htm.
} 
goes back to this sort of experience I've had all my life, and that's why I'm a musician. I had to be a musician." 66

Riley has maintained this profound emotional connection to music throughout his life. As a young adult, he studied music formally at Shasta College, San Francisco State University, the San Francisco Conservatory, and the University of California, Berkeley. ${ }^{67}$ One of his biggest influences, however, was his friend and fellow student-composer La Monte Young, whom Riley met at Berkeley. ${ }^{68}$ The two bonded over a love of John Coltrane's jazz, and Young also introduced Riley to gagaku (a type of Japanese classical music), Indian music, and psychedelic drugs like peyote (used originally by some Native American tribes in rituals and for medicine), all of which had a profound influence on Riley's own compositions and outlook. ${ }^{69}$ In the seventies, Riley began studying with Pandit Pran Nath, an Indian composer and vocalist known especially for his interpretation of the Kirana singing style. ${ }^{70}$ Riley states that he was profoundly influenced by Pran Nath's ability to "express himself freely" through the melodic ideas and "long, modal, sustained forms" of raga. ${ }^{71}$ Riley often accompanied Pran Nath's vocals on the tanpura, tabla, or with additional vocals. ${ }^{72}$ Evidence of his musical study with Pran Nath can be heard in many of Riley's works, including certain movements of Sun Rings.

\footnotetext{
${ }^{66}$ Robert Carl, Terry Riley's In C, 14. This quote is from an interview with Riley, conducted by the author-composer Carl on December 2, 2006.

${ }^{67}$ Edward Strickland, "Riley, Terry," Grove Music Online, Oxford Music Online (Oxford University Press, 2018), https://doi.org/10.1093/gmo/9781561592630.article.23474.

${ }^{68}$ Like Riley, La Monte Young is also considered to be one of the early pioneers of minimalism and he also studied with Pran Nath. He too frequently incorporates musical idioms from India in his compositions. For more information about Young, see Jeremy Grimshaw, Draw a Straight Line and Follow It: The Music and Mysticism of La Monte Young (Oxford: Oxford University Press, 2012).

${ }^{69}$ Carl, Terry Riley's In C, 18-25.

70 La Monte Young, "Pandit Pran Nath," Grove Music Online, Oxford Music Online (Oxford University Press, 2018), https://doi.org/10.1093/gmo/9781561592630.article.A2257147. For more on Pran Nath, see Alexander Keefe, "Lord of the Drone: Pandit Pran Nath and the American Underground," Bidoun 20 (2010): 113-119.

${ }^{71}$ Anil Prasad, “Terry Riley: Lighting Up Nodes,” Innerviews: Music Without Borders, https://www.innerviews.org/ inner/riley.html.

${ }^{72}$ Kronos Quartet, “Sun Rings,” KronosQuartet.org, https://kronosquartet.org/projects/detail/sun_rings.
} 
Yet Riley's idealization of the music of other cultures is, at its core, colonialist. His romanticization of the exotic Otherness of these cultures and their perceived ability to elevate music as we know it in the West is evidenced in his own words as he reflects on his youth:

"I was very concerned with psychedelia and the psychedelic movement of the sixties as an opening toward consciousness. For my generation that was a first look toward the East, that is, peyote, mescaline [sic], and the psychedelic drugs that were opening up people's consciousness. So I think what I was experiencing in music at that time was another world. Besides just the ordinary music that was going on, music was also able to transport us suddenly out of one reality into another. Transport us so that we would almost be having visions as we were playing ... I believe music, shamanism, and magic are all connected, and when it's used that way it creates the most beautiful use of music." 73

Indeed, his comments about "opening consciousness," experiencing "another world," and his mention of magic and shamanism indicate a colonialist belief that Eastern cultures somehow lend themselves to a secret kind of mystic wisdom and a deeper spiritual connection.

Additionally, most of the non-Western traditions to which Riley is drawn belong to societies that have lengthy histories with colonization--India was colonized by Great Britain; Native Americans were colonized by Spain and other European powers; even Coltrane's jazz is a byproduct of African diasporic music, recalling not only the colonization of Africa by Europe but also the horrific transatlantic slave trade. While these groups continue to experience lasting trauma and other unpleasant ramifications due to Western colonization, to Riley their cultural practices and especially musical practices are still free for the taking. ${ }^{74}$

\footnotetext{
${ }^{73}$ William Duckworth, Talking Music (New York: Schirmer Books, 1995), 169.

${ }^{74}$ A similar appropriation of Indian music was happening around the same time in the popular music realm. For more information, see Brian Ireland and Sharif Gemie, "Raga Rock: Popular Music and the Turn to the East in the 1960s," Journal of American Studies (2017): 1-38, doi:10.1017/S0021875817000925; Gerry Farrell, "Reflecting Surfaces: The Use of Elements from Indian Music in Popular Music and Jazz," Popular Music 7, no. 2 (1988): 189205; and Rodrigo Guerrero, "The Role of The Beatles in Popularizing Indian Music and Culture in the West," The Florida State University Undergraduate Research Journal 5, no. 1 (Spring 2015), 32-41.
} 
While studying with Pran Nath, Riley rarely used conventional musical notation. Riley has stated that he feels as though written scores work when musicians need to be "told what to do," but that he does not "like telling people what to do in general. It's not my most comfortable musical activity." 75 However, when Riley began collaborating with the Kronos Quartet, led by violinist David Harrington, Riley realized that his earlier method of using sparse or nonexistent notation would not work. According to Riley, Harrington told him after their first rehearsal (in which Riley presented the quartet with small sketches of notation upon which he hoped they would build through improvisation), "You know, I really think we need something totally written out for the way we work." 76 Despite feeling as though notation forces him to make "all the compositional decisions," Riley's relationship with the Kronos Quartet has proved a fruitful endeavor for both parties. ${ }^{77}$ In addition to Sun Rings, Riley has composed for Kronos Quartet thirteen string quartets, one quintet, and one concerto for string quartet. ${ }^{78}$ These beloved compositions include such pieces as "Sunrise of the Planetary Dream Collector," "Cadenza on the Night Plain," "Half-Wolf Dances Mad in Moonlight," and the collection Salome Dances for Peace, recorded for a 1989 Grammy-nominated album.

As some scholars and critics have noted, however, the Kronos Quartet's frequent engagement with non-Western musics can also be construed as appropriative. For instance, Timothy Dean Taylor refers to their 1992 work Pieces of Africa as an "old hegemony," arguing that despite the Kronos Quartet's commissioning of composers from the African continent, the title of the work treats the continent and its many cultures and musics as a monolith, which "continues the western mythologizing and inventing of the African continent that has gone on for

\footnotetext{
75 Prasad, “Terry Riley,” Innerviews.

76 Ibid.

77 Ibid.

${ }^{78}$ Kronos Quartet, “Sun Rings,” KronosQuartet.org.
} 
centuries." ${ }^{, 79}$ Additionally, because many of the composers of Pieces of Africa's various

movements do not use notation, the quartet's insistence on using written notation inevitably

transforms the authentic sounds created by the composers into a Westernized dilution of the

original music; when working with the Kronos Quartet, the composers had no choice but to sing

into a tape recorder and have someone else create a transcription of the recording--a transcription which often fails to "capture the subtleties of rhythm and inflection." ${ }^{80}$ Instead of adapting to the cultural and musical traditions which the Kronos Quartet likely intended to honor through their Pieces of Africa commission, they instead required the composers to conform to Western musical standards and practices.

Though the Kronos Quartet frequently performs live all across the world, they have only recorded but a small percentage of the pieces commissioned for them, including those composed by Terry Riley. Of the movements in Sun Rings, for instance, only one movement of ten has been recorded - the tenth, "One Earth, One People, One Love," which was recorded in 2015 on a fiveCD set entitled One Earth, One People, One Love: Kronos Plays Terry Riley. Like Pieces of Africa, however, the title of the final movement of Sun Rings treats the earth and its people as a monolith. In claiming that we are all "one people," Riley seems to erase the cultural and musical differences critical to identity formation and expression; likewise, in claiming that we live on “one Earth," Riley absolves colonizers of any past wrongs against Indigenous peoples and their

\footnotetext{
${ }^{79}$ Timothy Dean Taylor, “'Nothin’ but the Same Old Story’: Old Hegemonies, New Musics,” Global Pop: World Music, World Markets, 39-68 (New York: Routledge, 1997), 55.

${ }^{80}$ Ibid., 60. For more information about the Kronos Quartet, see Tully Potter, "Kronos Quartet," Grove Music Online, January 2001. For more critiques of the Kronos Quartet and their implementation of world music techniques, see David Bennett, "Postmodern Eclecticism and the World Music Debate: The Politics of the Kronos Quartet," Context 29-30 (2005), 5-15; Dave Headlam, "Re-Drawing Boundaries: The Kronos Quartet," Contemporary Music Review 19, no. 1 (2000): 113-40; Paul Murphy, "Kronos Quartet," The Musical Times 134, no. 1809 (1993): 617, doi:10.2307/1002796. For one critic's musings on world music and its place in the West, see David Byrne, "Crossing Music's Borders In Search Of Identity; 'I Hate World Music," New York Times, October 3, 1999, https://archive.nytimes.com/query.nytimes.com/gst/fullpage9901EED8163EF930A35753C1A96F958260.html.
} 
land, as if to say "the Earth belongs to all of us." This is a naive, unrealistic, and frankly harmful belief given that Indigenous populations like the Native Americans faced genocide if they refused to yield their territory to the European colonizers.

Riley's own writings maintain that Sun Rings was composed as a plea for a more loving, empathetic humankind:

"Do the stars welcome us into their realms? I think so or we would not have made it this far. Do they wish us to come in peace? I am sure of it. If only we let the stars mirror back to us the big picture of the universe and the tiny precious speck of it we inhabit that we call Earth, maybe we will be given the humility and insight to love and appreciate all life and living forms wherever our journeys take us." ${ }^{81}$

This approach, however, is inherently problematic. Riley's attempt to lump all of humankind into "one people," as the title of the final movement states, completely erases cultural difference and identity, which is itself one of the many problems created by colonialism. By arguing that we are "one people," Riley creates a selective history which fails to acknowledge the heinous treatment of indigenous people at the hands of Western colonialism. Michelle Alexander argues that colorblindness, or "the widespread belief that race no longer matters," reinforces a "racial hierarchy" akin to "earlier systems of control." 82 This same phenomenon happens when we collectively fail to acknowledge the crucial importance that colonialism has played (and continues to play) in issues of power and privilege across the globe. Riley's unintentional erasure of this history in advocating for a humankind that transcends all boundaries is a blatant demonstration of his own privilege--for many oppressed, impoverished, or otherwise suffering groups, transcending postcolonial status is not possible.

\footnotetext{
${ }^{81}$ Kronos Quartet, "Sun Rings,” KronosQuartet.org.

${ }^{82}$ Michelle Alexander, The New Jim Crow: Mass Incarceration in the Age of Colorblindness (New York: New Press, 2010), 11 and 13.
} 
In this chapter, I examine Riley’s Sun Rings from a postcolonial perspective, exploring the ways that the composer uses a problematic appropriation of the music of other cultures to represent outer space and the possibility of intelligent life elsewhere in the galaxy. The piece's ten movements, each of which represents a different "spacescape," vary drastically in styles ranging from folky and emotional to exotic and Otherworldly. ${ }^{83}$ Riley's frequent use of certain exotic instruments and musical techniques creates a problematic auditory alterity that not only portrays the extraterrestrial Other in an exotic light but also further exacerbates existing exotic stereotypes of non-Western cultures. ${ }^{84}$ The combination of non-Western elements and space audio to create these exotic spacescapes might be heard to construct a distinctly colonial soundone that evokes colonialism of the past through Eastern musical idioms while also suggesting space as the new frontier in the incorporation of recorded sounds from space.

\section{Space Audio}

Playing on common knowledge that sound cannot travel in space and thereby cannot be heard, the advertisements for Ridley Scott's famous 1979 sci-fi horror film Alien reads menacingly "[i]n space, no one can hear you scream." While the cleverly marketed sentiment no doubt elicits fear and perhaps a little bit of a thrill for horror film fans, the truth of the statement is undeniable: there is no sound in space. How then could Terry Riley incorporate sounds supposedly recorded in space into his musical composition for Sun Rings? The answer lies in

\footnotetext{
${ }^{83}$ Riley uses this term explicitly to describe the "separate musical atmospheres" in each movement of Sun Rings. See Ibid.

${ }^{84}$ For more information about musical techniques used to convey exoticism in Western art music, see Jonathan Bellman, The Exotic in Western Music (Boston: Northeastern University Press, 1998) or Ralph P. Locke, Musical Exoticism: Images and Reflections (Cambridge: Cambridge University Press, 2009).
} 
waves - not sound waves, the phenomenon that allows us to hear noises on Earth, but plasma

waves.

Aboard NASA's two Voyager vessels are instruments called plasma wave receivers, created and managed by the University of Iowa's Department of Physics and Astronomy. These apparatuses have recorded both plasma waves and low-frequency radio waves throughout the two spacecrafts' travels in the solar system and beyond. ${ }^{85}$ The receivers contain an automatic gain control device - a mechanism that, put in an oversimplified manner, converts the plasma waves into audio recordings. While some of these recordings contain interferences, such as the humming of the vessels' generators, the booms of their thrusters firing intermittently, and the knocking of other instruments on the spacecraft, the remainder of the sounds heard in Dr. Gurnett's space audio project are truly the "sounds of space," or rather, space's plasma waves converted into sound waves. ${ }^{86}$ The planets themselves do not create these sounds, but rather, certain occurrences in the planets' atmospheres generate the noise-for instance, the sounds labeled "Arrival at Jupiter" come from solar wind in the gas giant's magnetosphere, or "the magnetic bubble surrounding the planet." ${ }^{87}$ Other sounds in the project are taken from radio waves in the auroras found near Saturn's poles, intense radio bursts caused by record-breaking

\footnotetext{
${ }^{85}$ Plasma is a hot gas in space made of negatively charged electrons and positively charged ions. In measuring plasma waves, scientists assess certain frequencies of plasma such as its density or the effects of its magnetic field. Additionally, their measurements of low-frequency radio waves in space consists of assessing electromagnetism in areas where the frequency of plasma is high. For more information about plasma waves and radio waves in space, see W.S. Kurth, "Waves in Space Plasmas," http://www-pw.physics.uiowa.edu/plasma-wave/tutorial/waves.html. ${ }^{86}$ To read about some other projects that use similar technologies to study outer space, incorporate space sounds into music, and/or attempt to communicate with extraterrestrials, see: Flow Motion, "Astro Black Morphologies: Music and Science Lovers," Leonardo 39, no. 1 (2006): 23-27; Stefan Helmreich, "Gravity's Reverb: Listening to Space-Time, or Articulating the Sounds of Gravitational-Wave Detection," Cultural Anthropology 31, no. 4 (2016): 464-92, doi:10.14506/ca31.4.02; David Rosenboom, "Music Notation and the Search for Extra-Terrestrial Intelligence," Leonardo 26, no. 4 (1993): 273-74; and, Willard Van De Bogart, "Extraterrestrial Contact: Creating Xenolinguistic Sonic Messages for Extraterrestrial Communication - Ether Ship Electronic Music Orchestrations in the Anza-Borrego Desert," Technoetic Arts 12, no. 1 (2014): 47-73, doi:10.1386/tear.12.1.47_1.

${ }^{87}$ University of Iowa, "Voyager-2 PWS: Arrival at Jupiter," Space-Audio.org, http://wwwpw.physics.uiowa.edu/voyager/v2pws_ jupiter_arrival.html.
} 
solar flares on the Sun, and lightning in the atmospheres of various planets as described in the introduction to this chapter.

The similarities to these space sounds and the sounds of nature here on Earth are at times uncanny. For instance, "Arrival at Jupiter," an almost 27-minute long recording of noises created by solar wind, sounds at times like the high-pitched twitters of a bird ${ }^{88}$ At other times, it resembles hurricane-force winds recorded on a cell phone or some other inadequate recording device. Perhaps the most unsettling recording is Saturn's radio emissions, which sounds slightly like loud, whistling wind.$^{89}$ There is a large texture to the wind sounds - at their most intense, the simultaneous low pitches, mid-range pitches, and high pitches from this recording could instead resemble a chorus of human voices moaning and screaming. The eeriness of Saturn's auroral poles and their radio waves aside, it is only fitting that Riley be the composer to create the music for Sun Rings. Because of his lasting pursuit of spiritual connections with others and with the earth through music, he too likely heard Gurnett's space recordings as eerily familiar and evocative of nature.

Prior to Sun Rings, Riley's intermingling of spirituality, environment, and music was exemplified by his album A Rainbow in Curved Air (1969), which features a psychedelic cover art illustration of rainbows and clouds as well as a poem in the liner notes written by Riley himself. The poem portrays an idealized earth in which all firearms are "melted down and the metal poured back into the earth" and "the slaughter of animals was forbidden." The poem further evokes images of meadows and sunshine in place of urban centers and "sparkling rivers under blue skies streaked only with incense pouring from the new factories." ${ }^{90}$ The experimental

\footnotetext{
${ }^{88}$ Ibid.

${ }^{89}$ Bill Kurth, “The Eerie Sounds of Saturn's Radio Emissions,” Space-Audio.org, http://wwwpw.physics.uiowa.edu/space-audio/cassini/SKR1/t2003_324_0625_skr_anim.html.

${ }^{90}$ Terry Riley, Liner Notes to A Rainbow in Curved Air, Columbia Masterworks Records, MS 7315, CD, 1969.
} 
and improvisative music from A Rainbow in Curved Air incorporates psychedelic electric organ and modal harpsichord riffs that evoke the sounds of the Hindustani sārangī or harmonium, and Riley also incorporates the dumbec, a goblet drum originating from parts of Africa and Asia. In addition to its musically appropriative elements, the piece has close sonic ties to other music of the hippie movement from the 1960s and 1970s, a movement by which Riley was heavily influenced. Numerous scholars have examined the relationship between this new age spirituality born from this movement and the colonial appropriation of Indigenous cultures, and this ideology is clearly apparent in both A Rainbow in Curved Air and Sun Rings. Both works make excellent case studies to examine Riley's appropriation of Indigenous musical techniques, naive romanticization of a humanity free of difference, and idealized writings about the earth. ${ }^{91}$ As such, more research should be conducted in the future concerning Riley's colonial engagement with nature and the earth's environment in pieces like A Rainbow in Curved Air; this chapter, however, will focus instead on the music of Sun Rings and Riley's colonial engagement with outer space. $^{92}$

\footnotetext{
${ }^{91}$ For more writings about the appropriation of non-Western religion in the arts or in hippie culture and new age spirituality, see Barış Büyükokutan, "Toward a Theory of Cultural Appropriation: Buddhism, the Vietnam War, and the Field of U.S. Poetry," American Sociological Review 76, no. 4 (2011): 620-39; Miriam Hahn, "Playing Hippies and Indians: Acts of Cultural Colonization in the Theatre of the American Counterculture," PhD Dissertation, Bowling Green State University, 2014; Boaz Huss, "Spirituality: The Emergence of a New Cultural Category and its Challenge to the Religious and the Secular," Journal of Contemporary Religion 29. no. 1 (2014), 47-60, doi: 10.1080/13537903.2014.864803; Adrian Ivakhiv, "Nature and Self in New Age Pilgrimage," Culture and Religion 4, no. 1 (2003), 93-118; Myke Johnson, "Wanting to Be Indian: When Spiritual Searching Turns into Cultural Theft," Unsettling American: Decolonization in Theory \& Practice Blog, September 20, 2011, https://unsettlingamerica.wordpress.com/2011/09/20/wanting-to-be-indian/; David Pecotic, "Three Aboriginal Responses to New Age Religion: A Textual Interpretation,” Australian Religion Studies Review 14, no. 1 (2001), 65-81; Michael Santianni, "The Movement for a Free Tibet: Cyberspace and the Ambivalence of Cultural Translation," in The Media of Diaspora, ed. Karim H. Karim, 189-202 (London: Routledge, 2003), 194-196; Matt Sheedy, "Some Post-Colonial Narratives on Spirituality and Yoga," Bulletin for the Study of Religion, blog, May 20, 2013, http://bulletin.equinoxpub.com/2013/05/some-post-colonial-discourses-on-spirituality-and-yoga/; Yuk-Lin Renita Wong and Jana Vinsky, "Speaking from the Margins: A Critical Reflection on the "Spiritual-but-notReligious' Discourse in Social Work,” British Journal of Social Work 39, no. 7 (2009), 1343-59.

${ }^{92}$ Fairly recent ecomusicological scholarship that engages with intersections of music and environment include Travis D. Stimeling, "Music, Place, and Identity in the Central Appalachian Mountaintop Removal Mining Debate," American Music 30, no. 1 (2012): 1-29; Brooks Toliver, "Eco-ing in the Canyon: Ferde Grofề's Grand Canyon Suite and the Transformation of Wilderness," Journal of the American Musicological Society 57, no. 2 (2004): 325-68,
} 


\section{Sun Rings: Reception and Analysis}

Though at this time I have not yet been able to travel to the archives in the New York Public Library and the University of Louisville's Dwight Anderson Memorial Music Library to view the sole recording or score of Sun Rings, in this section I will attempt to construct an understanding of as much of Sun Rings as possible. My analysis will be based on the work's reception through critical reviews of earlier live performances, writings and interviews from Sun Rings' creators, and the brief video excerpts of six of the movements of Sun Rings contained in the video that the Kronos Quartet has posted on Youtube: "1. Sun Rings Overture," "2. Hero Danger," "3. Beepbopterismo," "4. Planet Elf Sindoori," "6. Earth/Jupiter Kiss," and "8. Prayer Central." ${ }^{93}$ I will conclude with a brief analysis of the final movement, "10. One Earth, One People, One Love," the only movement to be recorded in full. In my explorations of these seven movements of Sun Rings, I demonstrate the ways that Riley engages with problematic ideas about colonial contact with outer space and the extraterrestrial Other.

According to the Kronos Quartet's montage video, the first movement, "Sun Rings Overture," opens with images of spinning radar projected onto a large screen as the members of the quartet walk onto the stage one by one. ${ }^{94}$ As they take their places, Gurnett's voice is heard describing the various types of sound classifications that he and the University of Iowa Department of Physics and Astronomy have created for their space audio, such as "whistlers"

doi:10.1525/jams.2004.57.2.325; Denise Von Glahn, The Sounds of Place: Music and the American Cultural Landscape (Boston: Northeastern University Press, 2003).

${ }^{93}$ Kronos Quartet, "Kronos Quartet performs Terry Riley's Sun Rings," YouTube video, 16:42, posted December 2012, https://www.youtube.com/watch?v=GUlMyYuEyXw.

${ }^{94}$ Ibid. 
and "chorus." 95 Underneath his voice is a curious electronic drone, no doubt taken directly from the space audio project, that increases and decreases in volume unexpectedly. The electronic drone, juxtaposed dramatically by Gurnett's clearly natural, human voice, is somewhat unsettling. Sounding as if it were straight from a science-fiction film, the drone serves as the first clue that this journey through Riley's Sun Rings will be a depiction of places foreign, unknown, and exotic.

To further depict this electronic Otherness, after each member of the quartet has taken a seat, the performers intermittently wave their hands gracefully over a device on their music stands that causes a brief but gleaming green light to blip. This visual effect, coupled with the ever-searching on-screen radar, eerie drone, and voice (which goes on to discuss the frequencies of the sounds recorded in space) are combined with intermittent futuristic beeps that increase in speed and intensity as the movement goes on. According to critic Harvey Steiman, who saw Sun Rings performed in March 2016, this initial movement also features images and music from the Voyager golden record - a time-capsule sent into space that attempts to capture the essence of human life, meant for extraterrestrials' eyes and ears (or whatever sensory apparatuses they may have). ${ }^{96}$ Apparently, Riley even quotes one of the Beethoven works included on the Voyager golden record. ${ }^{97}$ Riley's blend of Western musical sounds with electronics and his emphasis on appropriative spirituality has much in common with composer Dane Rudhyar and the

\footnotetext{
95 The University of Iowa, "Sounds of Space," Space-Audio.org, http://wwwpw.physics.uiowa.edu/ dag/sounds 2. html

${ }^{96}$ For more on Voyager and the Golden Record, see Jet Propulsion Laboratory, "Voyager," NASA.gov, https://voyager.jpl.nasa.gov/golden-record/; Alexander Rehding and Daniel KL Chua, "Earth Music," Musicology Now blog, July 10, 2017, http://musicologynow.ams-net.org/2017/07/earth-music.html; and Alexander Rehding, "Beethoven in Space," OUPblog, December 3, 2017, https://blog.oup.com/2017/12/beethoven-in-space/.

${ }^{97}$ Harvey Steiman, “Sounds from Outer Space in Terry Riley’s Sun Rings.," Seen and Heard International, March 2016, http://seenandheard-international.com/2016/05/sounds-from-outer-space-in-terry-rileys-sun-rings/. http://seenandheard-international.com/2016/05/sounds-from-outer-space-in-terry-rileys-sun-rings/
} 
theosophists of the early twentieth century, whose music and beliefs strongly resemble that of Riley's. $^{98}$

As the introductory movement, "Sun Rings Overture" is particularly effective in creating an Otherworldly spacescape. Indeed, from the very first exotic images and electric sounds, it is clear that this piece is, in fact, about Otherness--particularly, Riley's interpretation of the musical Otherness of space. The drone and constant beeping of Gurnett's "Space Audio" make apparent that this piece incorporates "music" created by something unhuman, while Gurnett's voice and the quartet quoting more familiar works like that of Beethoven acknowledge that this journey is one in which humans are interacting with space in all its futuristic, unknown, and alien glory. Indeed, Charles Forsdick writes of exoticism that it can be described as "the process occurring in a colonial context whereby the foreign is absorbed into a home culture, essentialized, simplified, and domesticated in order to be presented not in the light of its original context but instead according to understandings imposed by the culture into which it is received." 99 This definition could describe Sun Rings itself: the piece is made up of audio recordings taken from space, which have been removed from their original context, edited and looped, and finally appropriated in a multimedia presentation in the Western art music tradition. In the same way that Western composers stole musical techniques from Indigenous cultures or Western ethnomusicologists created numerous recordings of Indigenous musics without permission, so too does Sun Rings appropriate musical material from space--material that is not technically ours. Sun Rings, then, is indeed for Western audiences somewhat of a voyeuristic glimpse of the exotic

\footnotetext{
${ }^{98}$ For more information on Dane Rudhyar, see Carol J. Oja, "Rudhyar, Dane," Grove Music Online, 2001, http:////www.oxfordmusiconline.com/grovemusic/view/10.1093/gmo/9781561592630.001.0001/omo9781561592630-e-0000024082 and Deniz Ertan, Dane Rudhyar: His Music, Thought, and Art (Rochester: University of Rochester Press, 2009).

${ }^{99}$ Charles Forsdick, "Revisiting Exoticism: From Colonialism to Postcolonialism," in Francophone Postcolonial Studies: A Critical Introduction, ed. Charles Forsdick and David Murphy, 46-55 (London: Arnold, 2003$), 48$.
} 
in the same way that depictions of 'Asian music' or 'African music' in the West (problematic even more so because these depictions often fail to acknowledge the vast cultural and musical differences throughout these continents) are exotic--the only difference is that Sun Rings instead depicts outer space, yet this exoticism is still apparent from the very first alien, unearthly sounds of the piece.

In the second movement, "Hero Danger," an underlying tabla groove emphasizes both the exotic nature of the work and also Riley's love of raga. In fact, the composer's veneration for the genre as evidenced by his earlier pieces and Sun Rings alike could be interpreted as a manifestation of Karl Marx's theory of commodity fetishism. ${ }^{100}$ For instance, Riley's adoption of both cultural and musical elements of Indian culture suggests his belief that these cultural traditions are mere commodities that might be collected and then projected into the rest of the world under the guise of a unique identity crafted by Riley himself. One can easily hear this commoditization of Indian culture in the second movement's exotic musical idiom. On top of the Indian drums, the Western string quartet bows out dancelike, folky rhythms as an image of the Earth rotates behind them sublimely. Punctuated every so often by two low staccato steady notes in the cello as well as a recurring triplet motif in the violins, the jaunty string melody is accompanied by interjections from space-whistling, tittering, swooshing — as if the two 'musical' idioms were having a conversation with one another. Riley's incorporation of tabla and space sounds in this movement is especially significant from a postcolonial standpoint. In one sense, the exotic sounds and rhythms of the tabla hearken back to colonialist images of India. The interweaving of this traditional Eastern instrument with a Western string quartet idiom

\footnotetext{
${ }^{100}$ For an English translation of Marx's seminal work wherein he introduces this theory, see Karl Marx, Edward B Aveling, Friedrich Engels, and Samuel Moore, Capital: A Critique of Political Economy, vol. 1, book 1, the Process of Production of Capital (London: Electric Book, 2001).
} 
musically conveys the cross-cultural exchanges that occur during colonization processes, such as Portuguese colonizers in India adopting not only the customs of the locals but also choosing to inter-marry. ${ }^{101}$ However, this blending of these two different musical idioms also recalls the violent domination of Indigenous people in India, who, despite the country's relatively new independence, are still suffering from colonialism's lasting effects, especially in the realm of socioeconomic inequality among India's citizens. ${ }^{102}$ In adding space sounds to this colonial musical mixture, Riley seems to suggest that outer space presents a new opportunity for discovery and exploration in the same way that the East once did for Europeans. His evocation of both India and outer space in one movement draws on cliched orientalist tropes depicting the exploration of distant places and worlds, despite the fact that this same kind of colonialism has caused lasting harm to other humans, like those living and still suffering in postcolonial India.

For Riley, the title of the third movement is an onomatopoeia. Having listened to one of Gurnett's recordings taken from the magnetosphere of Jupiter's largest moon, Ganymede, Riley recalled, "it sounded to me like a voice saying, 'beebopterismo,' so that's the starting point for one of the movements." 103 The brief excerpt of this movement in the video montage relays a fastpaced, somewhat erratic melody. ${ }^{104}$ The quartet plays a repeated six-figured hemiola in rhythmic unison, one that is not especially tonal in its harmonic language. At the end of each phrase, the violins interrupt the pattern with a busy and unpredictable melodic pattern that is almost reminiscent of R2D2's bizarre beeping. Though this similarity is likely unintentional, it is easy to hear Star Wars' version of a futuristic alien 'language' in Riley's writing because the movement

\footnotetext{
${ }^{101}$ Ania Loomba, Colonialism/Postcolonialism, 2d ed (London and New York: Routledge, 2005), 117.

102 In one section of her book, Loomba explores the writings of Mahasweta Devi, who describes the upper-class Indian government's discrimination and disdain towards the working-class, as well as people starving to the extent that their small, frail bodies appear to be those of children until examined more closely. Ibid., 31.

103 Savage, "NASA Music Out of This World," NASA.gov.

${ }^{104}$ Kronos Quartet, “Kronos Quartet performs Terry Riley's Sun Rings,” YouTube video.
} 
evokes a science-fiction kind of Otherness. Behind the quartet's strange melody, a black and white spacecraft appears to rotate aimlessly, weightless in space. During each individual articulation of the six-figured pattern, the projected image changes to reveal a new mathematical or scientific equation which covers the screen in a barrage of diagrams and theories-Earth's own futuristic language.

The fourth movement, "Planet Elf Sindoori," is one of the most beautiful of Riley's compositions in Sun Rings, and also one of the most evocative of the East. The title is likely derived from the Hindu word "sindoor," which translates in English to "vermilion." Sindoor is a red powder that practicing Hindu women wear along the part of their hair, or as a dot on their forehead, to indicate that they are married. This tradition is practiced widely by Hindu women, and is referenced in the Soundarya Lahari (in English, Waves of Beauty), a famous collection of hymns celebrating the goddess Parvati, written in Sanskrit and attributed to Adi Shankara. ${ }^{105}$ An excerpt about sindoor from this text reads as follows:

\begin{tabular}{|c|c|}
\hline Sanskrit & English \\
\hline $\begin{array}{l}\text { Tanothu kshemam nas tava vadhana-saundarya lahari } \\
\text { Parivaha-sthrotah-saraniriva seemantha-saranih } \\
\text { Vahanti sinduram prabala-kabari-bhara-thimira- } \\
\text { Dvisham brindair bandi-krtham iva navin'arka } \\
\quad \text { kiranam; }\end{array}$ & $\begin{array}{l}\text { Oh mother, let the line parting thine hairs, } \\
\text { Which looks like a canal, } \\
\text { Through which the rushing waves of your } \\
\text { beauty ebbs, } \\
\text { And which on both sides imprisons } \\
\text { Your Vermillion, which is like a rising } \\
\text { sun, } \\
\text { By using your hair which is dark like } \\
\text { The platoon of soldiers of the enemy, } \\
\text { Protect us and give us peace. } \\
\text { Translation by P.R. Ramachander }{ }^{106}\end{array}$ \\
\hline
\end{tabular}

${ }^{105}$ For one version of this text, see Sri Sankaracharya, Saundarya-Lahari (Ganesh \& Co., 2013).

${ }^{106}$ P.R. Ramachander, "Soundarya Lahari," Sankaracharya.org, http://www.sankaracharya.org/soundarya_lahari.php. Another translation reads as follows: "Let (your) line of hair parting, which is like the path of an overflowing stream from the wave of your facial beauty, which bears the 
Though Riley has engaged deeply with Eastern religions, it is unclear if the composer is familiar with this particular text. ${ }^{107}$ Nonetheless, there are themes in this hymn that are reminiscent of some ideas in Riley's "Planet Elf Sindoori” movement. For one, this particular movement is musically soft, beautiful, gentle - the word 'feminine' comes to mind, especially to a society that observes traditional gender roles - and perhaps reminiscent of Parvati herself, the goddess of love and fertility. The image of a rising sun in the hymn correlates directly with Sun Rings' celestial themes, and perhaps even with the rising pentatonic melodies played by the quartet in the movement. The final plea for protection and peace especially recalls Riley's own words: "Do they wish us to come in peace? I am sure of it." ${ }^{108}$

The musical idiom in "Planet Elf Sindoori" is indeed peaceful, if exotic. On top of clinking Indian percussion and drones, members of the quartet, surrounded by glowing lights scattered across the stage, take turns bowing a delicate pentatonic melody. One player initiates the melody, then another player repeats it in a mesmerizing orientalist call-and-response. Behind the quartet is a projected image of the night sky, stars twinkling. As if among the stars themselves, individual members of the quartet intermittently wave their hands over the green lights on their music stands as they did in the first movement. Clanging and whistling from

vermillion powder, (like) the ray of the newly (risen) sun, (and) which is as if captured by the very great mass of hair, like the multitude of foes (in the form of) darkness, grant our well-being." See Rama Venkatraman and Uma Krishnaswamy, Saundarya Lahari of Adi Sankara: A Tamil and English Translation, 72, http://www.vidyavrikshah.org/SOUNDARYALAHARI.pdf.

107 Of his time in India studying with Pran Nath (a Sufi), Riley states that he was influenced by both Islam and Hinduism: "I was going to a lot of holy spots and shrines, putting my head down on the base of tombs and saying prayers. I did all of that because I wanted to feel what it was like to do that, to see if anything could be awakened, and things did. You can't do stuff like that without there being some real experiences." See Prasad, "Terry Riley," Innerviews.

${ }^{108}$ Kronos Quartet, “Sun Rings,” KronosQuartet.org. 
Gurnett's "Space Audio" again ties together the Eastern images evoked by Riley’s exotic musical idiom and our own questionable colonial future among the stars.

There is no excerpt of the fifth movement, "Earth Whistlers," on the Kronos Quartet's montage video, but critic Josef Woodard has suggested that this movement's content is based on "lyrical Asian sonorities." 109 This appraisal is obviously problematic in that it assumes that the entire continent of Asia has but one type of sound--an exotic one, at that--one noticeably Other than usual Western sonorities. Woodard was likely referring to pentatonicism or perhaps octatonicism, the cliched scalar patterns that are often used to depict "Asian music" in the West. As I have already mentioned, however, there are vast musical differences coexisting not only across the continent of Asia but also within various genres--for instance, there are many different types of Indian raga, and Japanese gagaku is performed in multiple different settings depending on context and audience, often with different instrumentation. Woodard's treatment of the music of Asia as a monolith is perhaps equally as problematic as one might perceive Riley's appropriation of these musical idioms to be.

"Earth/Jupiter Kiss," the sixth movement of Sun Rings, is the next movement featured in the montage video. ${ }^{110}$ In this movement, tinkling whistles from Gurnett's "Space Audio" play continuously while a violin player bows a pattern of slow, legato notes that bend downward by a fourth. The cello unhurriedly plucks a repeated bass note below as the Earth spins serenely behind the quartet. The movement is mournful, likely evoking the somber aftermath of violent tragedies like 9/11, which occurred during the time that Riley was composing Sun Rings and which had a profound impact on his vision for the piece. Of the terrorist attack's influence on

\footnotetext{
109 Josef Woodard, "Science, Art Share Stage in Sun Rings," Los Angeles Times, October 16, 2003, http://articles.latimes.com/2003/oct/16/news/wk-woodard16.

${ }^{110}$ Kronos Quartet, “Kronos Quartet performs Terry Riley's Sun Rings,” YouTube video.
} 
Sun Rings, visual designer Williams said, "There is nothing overtly political about it, but it does have quite a sombre [sic] quality. It is about our position in the cosmos, and it is about our humanity, which is in stark contrast to the petty tribalism afflicting us here on Earth. It gives us a context." 111 As the Earth rotates soundlessly behind the quartet during this solemn movement, it is indeed easy to imagine that the creative forces behind Sun Rings used this movement to express their own sorrow and grief at our divided, warring planet.

Though the seventh movement "The Electron Cyclotron Frequency Parlour" is also absent from the Kronos Quartet's video, Woodard writes that it is "upbeat" and at times resembles a "dance piece" with "tango" influences ${ }^{112}$ The tango is yet again another musical style appropriated from the traditions of other countries; in this case, Argentina, which was colonized by Spain, and Uruguay, which experienced extensive conflict due to fighting amongst colonists from Britain, Portugal, and Spain. Without a musical recording, however, and without any more interpretations from critics who have witnessed it, this movement is impossible to analyze further.

There is, however, an excerpt of the eighth movement, "Prayer Central," on the montage video. Riley describes this movement as a "polyphony of prayers that goes drifting up." 113 Indeed, at a certain point in this movement featuring a large chorus, the string quartet and human voices pass back and forth a rising pattern as if it were a hopeful prayer lifting into the heavens. The use of human voices here is particularly meaningful to the composer, who has stated, "The addition of the two movements with the choirs was to further emphasize that this work is largely

\footnotetext{
${ }^{111}$ Robin Stringer, "Terry Riley: Written in the Stars," Independent, March 21, 2003, https://www.independent.co.uk/arts-entertainment/music/features/terry-riley-written-in-the-stars-111720.html.

${ }^{112}$ Woodard, "Science, Art Share Stage in Sun Rings."

${ }^{113}$ Kronos Quartet, "Sun Rings," KronosQuartet.org. For the video excerpt of "Prayer Central," see Kronos Quartet, "Kronos Quartet performs Terry Riley's Sun Rings," YouTube video.
} 
about humans as they reach out from earth to gain an awareness of their solar system neighborhood." 114 Though the Kronos Quartet's video only features one of these movements involving the choir, "Prayer Central," Riley's intention for Sun Rings to tell a story about humans reaching out is clear from this movement alone. The music, climbing higher and higher, suggests a yearning for the celestial unknown. Yet, in keeping with the stated goals of Sun Rings' creators, it is likely also that the nature of these rising prayers involves peace, both here on Earth and also out there in the mysterious cosmos. This movement transitions into the ninth movement, "Venus Upstream," which is absent from the video but which Woodard describes as "featur[ing] an image of a gyroscope, a handy metaphor for both the miracle and the fragility of the universe and for the irresolute kinetics of the music." This vague description is currently the only clue available into this movement's unknown sights and sounds. ${ }^{115}$

Perhaps the most problematic message of all lies in the final movement of Sun Rings"One Earth, One People, One Love"- the only movement to be recorded in full. The title is adapted from poet Alice Walker's own mantra after 9/11; throughout this movement, Walker's voice reverently repeats the mantra-title in a blatant attempt to manifest harmony among Earth's people. Riley has been explicit in his intentions for Sun Rings, which becomes most apparent in this final movement: "It became a piece more about understanding and compassion than about space exploration. I thought it had to have one message about how we human beings have to grow before we take our culture out into space." ${ }^{\prime 16}$ Indeed, in addition to the horror of the 9/11 terrorist attacks, scholars of postcolonial studies point out several other current trends negatively

\footnotetext{
114 Ibid.

115 Woodard, "Science, Art Share Stage in Sun Rings."

${ }^{116}$ Prasad, “Terry Riley,” Innerviews.
} 
affecting global affairs today, including climate change and globalization. ${ }^{117}$ But Riley's

comment that we need to change before we as human beings take "our culture" to space suggests that he believes that all of us are equally responsible for the violence amongst people and the destruction of the planet. But as I have hoped to demonstrated already, humans do not have one culture; rather, each individual continent contains multitudes of diversity. But colonialist ideology has sought to control or stamp out these differences in order to gain power, and Riley seems unaware that his own musical appropriations are a kind of cultural colonialism that is a demonstration of power over groups that are already underrepresented and have had their agency taken away by colonial practices. Yes, we are in agreement that before we can cohabitate peacefully with any extraterrestrial life that might exist, we must cease the violence, exploitation, and domination of other members of humankind and of our planet--but it appears that Riley's hopeful perspective blinds him to the potential ways that his work might implicitly perpetuate problematic colonialist thinking.

Musically, "One Earth, One People, One Love" has a meditative ambiance through its repetitions, hypnotic legato string melodies, and slow underlying percussive groove. Writer Dan Coren has described the movement as "a long, lyrical plateau punctuated by the repeated words, 'One world [sic], one people... one love."'118 To set the tone and create the atmosphere of selfreflection that "One Earth, One People, One Love" attempts to evoke, the movement opens with

\footnotetext{
${ }^{117}$ See Loomba's discussion of these ideas and the ideas of some of the foremost scholars on these subjects in Loomba, Colonialism/Postcolonialism, 250-265.

${ }^{118}$ Dan Coren, “Kronos Quartet Plays Sun Rings,” BroadStreetReview.com, April 28, 2007, https://www.broadstreetreview.com/music/Kronos_Quartet_plays_Sun_Rings\#. Another critic was not so kind, referring to this movement as "dross, [...] New Age drivel." See R.M. Campbell, "Kronos Quartet Performs Terry Riley's Sun Rings," Seattle Post-Intelligencer, July 20, 2003, https://www.seattlepi.com/news/article/KronosQuartet-performs-Terry-Riley-s-Sun-Rings-1119751.php.
} 
a recording of Eugene Cernan, commander of the Apollo 17 space mission, describing our planet from space with awe:

"You have to literally just pinch yourself and ask yourself the question silently: Do you really know where you are at this point in time and space, and in reality and in existence? When you look out the window and you're looking back at the most beautiful star in the heavens - the most beautiful because it's the one we understand and we know it ... We're home. It's humanity; it's people, family, love, life. And besides that it is beautiful. You see from pole to pole and across oceans and continents. You can watch it turn, and there's no strings holding it up. And it's moving in a blackness that is almost beyond conception." 119

Underneath Cernan's profound observation, a groove of metallic clinking and a low-pitched bell pulses gently. As Walker begins to repeat her mantra, a moving, slow melody alternates between solo cello and the other members of the quartet in a gentle call-and-response. Above them is the delicate swooshing sound of wind in space, a recording from Gurnett's space audio. Each of these sonic effects happen in waves - they come from nothingness, crescendo, and then decrescendo back into nothingness - over and over again in a mesmerizing ocean of sound. Yet, this movement is also almost mournful in its dramatic, legato cello melody. It is clearly Riley's plea for humankind to choose love over violence.

Of the visuals in "One Earth, One People, One Love," Woodard writes, "[1]ovely images of earthly life bring the assembled energies home in the final movement." ${ }^{120}$ Indeed, behind the quartet is a montage slideshow of various images of Earth - the same ones included on the Voyager spacecraft's Golden Record. ${ }^{121}$ Snapshots of heteronormative human families, landscapes, and animals bring the piece into context — it may be a multimedia journey across outer space, but ultimately the piece is about us, our past, and our future. In Sun Rings, Riley

\footnotetext{
${ }^{119}$ This transcription comes from David Harrington, "Something Precious," Letters to the Future: The Paris Climate Project, https://letterstothefuture.org/letter/117/something-precious/.

${ }^{120}$ Woodard, "Science, Art Share Stage in Sun Rings."

${ }^{121}$ Kronos Quartet, "Sun Rings," KronosQuartet.org.
} 
acknowledges that we come from a civilization wrought with violence and hate, but he fails to realize that his depiction of space exploration as a pathway to new frontiers perpetuates this dangerous colonialist thinking. The problematic oriental and exotic musical idioms Riley uses in Sun Rings--both the non-Western musical instruments and practices as well as the space audio-imply that outer space is free for the taking in the same way that India, the New World, Argentina, Uruguay, and too many other countries appeared to the entitled European settlers. Though Riley seems to believe that his music is contributing to the solution of humankind's problems, his theft of the music of other cultures might instead be heard to perpetuate colonial power structures.

\section{Conclusion}

Postcolonial studies offers a useful approach to understanding Sun Rings and Riley’s optimistic point of view, especially when he says, "I saw how the country was changing [in the wake of 9/11], and I knew the meaning [of Sun Rings] had to be motivated by peaceful intentions - not revenge or patriotism, but real meaning about where we are as human beings, and where we should be going." ${ }^{122}$ In this statement, he suggests that revenge and patriotism are the antithesis of peace, and there is perhaps some truth to this. For instance, Al-Qaeda and Osama Bin Laden stated outright that 9/11 was itself an act of revenge on the United States for its sanctions against Iraq and its military presence in Saudi Arabia during the Gulf War. ${ }^{123}$ Significantly, both Iraq and Saudia Arabia have a long history with colonization: Iraq was

\footnotetext{
122 Ibid.

${ }^{123}$ CBC News, "Bin Laden Claims Responsibility for 9/11,” CBC, October 29, 2004, https://www.cbc.ca/news/world/bin-laden-claims-responsibility-for-9-11-1.513654; Osama bin Laden, "Bin Laden's Fatwa," PBS Online News Hour via Internet Archive Wayback Machine, October 31, 2001. https://web.archive.org/ web/20011031024057/http://www.pbs.org/newshour/terrorism/international/fatwa_1996.html.
} 
conquered as early as the thirteenth-century by the Mongol and Ottoman Empires until Britain's invasion of Iraq after World War I, while Saudi Arabia was likewise ruled by the Ottomans until World War I. Though President Franklin D. Roosevelt's decades-old agreement to protect the Saudi regime in exchange for oil is still in effect today, tensions between the United States and Saudi Arabia in the wake of the murder of journalist Jamal Khashoggi do not bode well for the future of that relationship. ${ }^{124}$

Riley likewise cites patriotism as another negative force at odds with world peace.

Indeed, though perhaps better described as nationalism in this case, this phenomenon was so powerful in Germany in the first half of the twentieth century that it led to attempted genocide. Germany has a history of other kinds of violence and oppression having also colonized portions of Africa during the Scramble of Africa toward the end of the nineteenth century until their defeat in the First World War. And while the Nazi regime was also thankfully defeated years later, its terrifying brand of nationalism appears to have remained strong, hidden away in the hearts and minds of many, including that of the current President of the United States who, as I was in the process of writing this chapter, referred to himself proudly as a nationalist even though "we're not supposed to use that word."125 One need only read about recent white nationalism in the United States to know that Riley is right about one thing - the lasting hate and violence bred by nationalism is dangerous and deadly. ${ }^{126}$

\footnotetext{
${ }^{124}$ For one of many recent news articles on this subject, see David Gauthier-Villars and Margherita Stancati, "Erdogan Says Saudis Planned Murder of Journalist Jamal Khashoggi," Wall Street Journal, October 23, 2018, https://www.wsj.com/articles/turkeys-erdogan-saudi-journalist-was-murdered-1540287925.

${ }^{125}$ Again, for one of many recent news articles on this subject, see Chris Cillizza, "Donald Trump Used a Word He's 'Not Supposed To.' Here's Why," CNN, October 23, 2018, https://www.cnn.com/2018/10/23/politics/donald-trumpnationalism/index.html.

126 Southern Poverty Law Center, "White Nationalist," Southern Poverty Law Center, https://www.splcenter.org/fighting-hate/extremist-files/ideology/white-nationalist.
} 
Yet Riley and the Kronos Quartet alike seem to believe that in creating Sun Rings, they have eschewed these colonialist ideals of revenge and patriotism in favor of peace. Yet, recall Michelle Alexander's writings about erasure; the entire premise of Sun Rings unintentionally rests on the notion that we erase these important histories of conquest and mistreatment. Thus, rather than making a case for peace, Riley's ten movement work appears to perpetuate an age-old problematic ideology of the non-Western Other. Likewise, the Kronos Quartet's involvement with Sun Rings, coupled with their decades-long exercise of misrepresenting of the musical traditions of other cultures, might be detrimental to the Indigenous populations from which these traditions are taken. Sun Rings may on the outside appear to be a wholesome plea for peace, but upon closer scrutinization, it functions instead as a negative musical manifestation of Riley's and the Kronos Quartet's sonic ideas of alterity. The only difference between Sun Rings and other exoticist pieces is that, in the former, the stereotypical depiction of the Other is projected onto the mysterious unknown of outer space--the stars, the planets, and the possibility for intelligent life--rather than humans. 


\section{Hearing Space Through an Astronaut's Ears: Colonial Themes and Masculinity in Chris Hadfield's "Songs About Space" Spotify Playlist}

The International Space Station orbits the Earth serenely, accompanied by the gentle chords of a piano. On board, a laminated sign taped to a padded door reads "RECORDING IN SESSION." Inside, a lone astronaut stares longingly out of a large circular window with breathtaking views of his home planet shrouded in clouds. As he clutches a handle on the wall so that he does not float away in the microgravity, he solemnly turns his face towards the camera and begins to sing the famous line: "Ground control to Major Tom."

In May 2013, while aboard the International Space Station, Commander Chris Hadfield recorded the first ever music video filmed in space. His inventive cover of David Bowie's celebrated "Space Oddity" went viral, prompting BBC News to refer to the now-retired Canadian spaceman as "the most famous astronaut since the days of Neil Armstrong and Yuri Gagarin." 27 Indeed, Hadfield is not only an accomplished astronaut and former military pilot, but during his time on the ISS he also became a social media giant. In addition to taking tens of thousands of photographs, he also documented his daily life in space through Twitter posts and humorous videos that depicted everything from brushing his teeth in microgravity to the intricacies of astronaut cuisine.

Yet it was perhaps his engagement with music while floating through the ethers that touched fans most. On Christmas Eve 2012, Hadfield uploaded a composition that he cowrote with his brother Dave to YouTube. Entitled "Jewel in the Night," it was the first song ever recorded in space. As he strums a guitar, Hadfield sings wistfully for the "jewel in the night" that is planet Earth. His lyrics convey feelings of love, fondness for home, and an evocation of "the

\footnotetext{
${ }^{127}$ Phallab Ghosh, "Chris Hadfield says NASA's job is not to 'titillate,"” BBC News, May 13, 2013, https://www.bbc.com/news/science-environment-22483934.
} 
message of peace / from Bethlehem so long ago." ${ }^{128}$ As is typical of the Christmas carol tradition, the song's melody is simple, and the text is set strophically, minus a few stanzas that provide a slight variety. Played in a subdued minor mode, Hadfield's "Jewel in the Night" emphasizes both his longing for home and his reverence for the Christian tradition that celebrates the birth of Jesus.

Hadfield later included "Jewel in the Night" on his 2015 album Space Sessions: Songs from a Tin Can, much of which was also recorded in space. The album title is a reference to Bowie's "Space Oddity," wherein Bowie sings that he is "floating in a tin can" while in space. Fittingly, Hadfield's famous rendition of "Space Oddity" is the only cover included on the album. The rest of the original compilation features several songs that were written jointly with members of Hadfield's family — particularly, he wrote several with his brother Dave, and one with his son Evan—or songs that were inspired by members of his family, such as the love song for his wife, "I Wonder if She," or the "Space Lullaby" that he wrote for his daughter. All of Hadfield's music has a folky feel, featuring the acoustic sounds of the Larrivée P-01 parlor guitar that resides on the ISS and the humble, untrained vocals of a lifelong music lover seeking to share his passion with others. Aside from the lone cover, the songs from Space Sessions engage with subjects that range from weightlessness in the microgravity of space to the dangers of takeoff to sentimental family memories that are clearly special to the astronaut and evoke a feeling of longing similar to that of "Jewel in the Night."

After the release of "Jewel in the Night," Hadfield's nostalgia and appreciation for life on Earth was further emphasized a few months later in a musical collaboration with Canadian rock

\footnotetext{
${ }^{128}$ Shaina Pearlman, "Listen to the First Song Recorded in Space," Paste, December 28, 2012, https://www.pastemagazine.com/blogs/awesome_of_the_day/2012/12/listen-to-the-first-song-recorded-inspace.html.
} 
band Barenaked Ladies. The song, called "I.S.S. (Is Somebody Singing)," was performed as a duet while Hadfield was on the ISS and Barenaked Ladies lead singer Ed Robertson was still on Earth, making it the first "space-to-Earth musical collaboration." 129 The song's upbeat rock groove and heartening lyrics paint a portrait of a united, idealized Earth in much the same way as Terry Riley's New Age spirituality does in "One Earth, One People, One Love." Like "Jewel in the Night," the song's lyrics contain numerous feel-good sentiments about human life on Earth, including Hadfield's observation that “you can't make out borders from up here / just a spinning ball with a tiny atmosphere" and, in reference to the Space Race of the twentieth-century, "what once was fueled by fear / now has fifteen nations orbiting together here." And while Hadfield's musical and social media personae are intended to be inspiring and positive, from a postcolonial perspective his erasure of borders in the lyrics could be read as a colonial gesture. Indeed, his lyrics imply that these borders are not important and thereby play into colonial narratives that minimize the political and cultural autonomy crucial to identity formation that borders should ideally grant a given territory.

As an astronaut, Hadfield is somewhat of a modern-day colonist. During his career, he spent a total of 166 days in space, a mostly unexplored domain in which he and others settled via the ISS, with the long-term hope that the space station would "be a stepping stone to [colonizing] Mars. ${ }^{\prime 130}$ When asked what he thought about the possibility of embarking on a one-way mission to the red planet, the spaceman compared the endeavor to earlier colonial conquests: "In the history of humanity, we've had a lot of one-way voyages. We've left home to go settle

\footnotetext{
${ }^{129}$ CBC Music, "Chris Hadfield and Barenaked Ladies - I.S.S. (Is Somebody Singing)," uploaded February 12, 2013, https://youtu.be/AvAnfi8WpVE. The song also features backup singers from the Wexford Gleeks. It was commissioned by CBCMusic.ca, The Coalition for Music Education, and the Canadian Space Agency.

${ }^{130}$ Ghosh, "Chris Hadfield says NASA's is not to 'titillate."
} 
someplace new." ${ }^{131}$ In another interview, Hadfield referred to the colonization of Mars as "natural human progression," insinuating that it is both human nature for people to seek exploration and discovery, but also that the progression of technology enables humanity to travel further and further in their conquests. ${ }^{132}$

Yet, Hadfield's rendition of history is selective. As I hope to have already demonstrated in earlier chapters, colonization is much more than merely packing up and moving someplace else as new technology allows. Rather, it has historically been a destructive and devastating process that, at its ugliest, has nearly eradicated indigenous peoples and practices through allencompassing subjugation, having exacerbated the economic status of developing countries and depleted environmental resources to distressing levels. Perhaps Hadfield neglects to acknowledge the dark truths of these "one-way voyages" in humanity's history because they do not fit into his typical upbeat, inspirational narrative; or perhaps it is because, as a man with the privilege of European heritage, he has not been subjected to the same hardships as the indigenous people who lived in the land that he now calls home. No matter the reason, his view of history is ironic considering that he is simultaneously an outspoken advocate for Earth's environment, going as far as publishing an online call-to-action which relays his concerns about the depletion of fossil fuels and our need for renewable energy, problems that have been exacerbated immensely by colonialism. ${ }^{133}$ Such a contradictory approach to the practice of colonization-

\footnotetext{
${ }^{131}$ CBC News, "Chris Hadfield Interview," interview by Peter Mansbridge, YouTube, uploaded January 20, 2014, https://youtu.be/kGRXWtzWz-Y.

${ }^{132}$ Ghosh, "Chris Hadfield says NASA's is not to "titillate."

${ }^{133}$ Chris Hadfield, "We Should Treat the Earth as Kindly as We Treat Spacecraft," Wired, November 25, 2013, https://www.wired.com/2013/11/chris-hadfield-wired/. For more information on the environmental impacts of colonialism, see, for example, Lawrence Wood, “The Environmental Impacts of Colonialism," Bridgewater State University Virtual Commons, Honors Program Theses and Projects, December 17, 2015, https://vc.bridgew.edu/honors_proj/119/; Paul R. Josephson, Resources Under Regimes: Technology, Environment, and the State, New Histories of Science, Technology, and Medicine (Cambridge: Harvard University Press, 2004); Stephen Mosley, The Environment in World History, Themes in World History (New York: Routledge, 2010).
} 
viewing the process optimistically as it relates to a possible Mars mission, while condemning its most detrimental environmental consequences — brings to mind the question of how Hadfield might feel about extracting natural resources from other planets. Is fossil fuel depletion acceptable to the environmentally conscious astronaut as long as it happens elsewhere in the solar system? Like dealing with a child that has irreparably damaged her favorite toy and then expects to be gifted another one, assuming that we would not cause equal amounts of destruction to any other planet that we hope to colonize as we caused on Earth is frankly dangerous, naïve, and unsustainable. Hadfield, more than anyone, should realize that, lest we change our terrestrial environmental practices before we move outward, we could very well destroy the entire solar system by continuing earlier colonial practices in space.

The astronaut's views about space colonization become even more complicated when considering his thoughts regarding the possibility that intelligent extraterrestrials exist. According to Hadfield, "the odds are fundamentally infinite that there's life somewhere besides Earth." ${ }^{134}$ Yet, despite his near certainty that alien life exists, the former ISS Commander apparently does not take any issue with space colonization for this reason or for any other (from interviews, it seems that his only concern is the safety features of the vessel that would transport the colonists). ${ }^{135}$ It is likely that such a learned man is not ignorant the inhumane exploitation and subjugation of humans that resulted from earlier colonization in Earth's history, so it is curious that would he not assume that these same horrific consequences will happen to intelligent extraterrestrial life during our future space conquests — certainly as an astronaut, Hadfield would

\footnotetext{
${ }^{134}$ Christine Nguyen and Will Wei, producers, “Astronaut on Aliens," Tech Insider, interview with Chris Hadfield, uploaded November 17, 2015, https://youtu.be/eeOZHDM-Lgc. He echoes this same sentiment in BBC 5 Live, "Chris Hadfield: 'Odds are Enormous' That Alien Life Exists," uploaded July 27, 2015, https://youtu.be/GVaxCrdWZDc.

${ }^{135}$ CBC News, "Chris Hadfield Interview."
} 
have an extensive education in science and mathematics, but perhaps he has not considered these issues from a cultural perspective. Either way, as a person who claims that life in space has given him a new sense of reverence and appreciation for humankind, one wishes that Commander Hadfield might be more vocal about the possible dangers of space colonization and its effects on both life and environment. From his privileged platform as an admired astronaut and an authority on space life, Hadfield's voice could be influential in advocating for a new approach to space exploration, one that might prevent us from reliving the violent past in our future spaceflight endeavors. It would be a significant act of solidarity for all life if Hadfield were to educate his many social media followers about the truths of colonization, the need for terrestrial reparations that attempt to make up for the atrocities committed against indigenous people here on Earth, and the importance of not repeating that chapter of history in space explorations of the future. However, his voice on all of these matters is, unfortunately, completely silent.

Since his return home, though, one of the many topics to which he has given voice is music — specifically "songs that remind [him] of [his] time orbitting [sic] the Earth," which he compiled in a public Spotify playlist on October $8,2015 .{ }^{136}$ Describing the playlist's contents, Hadfield writes that "a handful of tracks have a space theme, while other's [sic] embody the serenity \& grace I felt during my space explorations." ${ }^{\text {137 }}$ The playlist contains a variety of genres, from classic rock to orchestral art music to jazz, even featuring one of the original songs on his own Space Sessions album. Unsurprisingly, a large percentage of the included tracks are written and performed by Canadian musicians, demonstrating Hadfield's pride in his country and

\footnotetext{
${ }^{136}$ Chris Hadfield, "Songs About Space," Spotify, October 8, 2015, accessed January 17, 2019, https://open.spotify.com/playlist/799tsdWb2AvMKr3Yd6Oiph.

${ }^{137}$ Ibid.
} 
his appreciation for all that evokes "home" to him. ${ }^{138}$ Yet, the playlist is overwhelmingly malein fact, of the nineteen songs, only one single track is written and performed by a woman. ${ }^{139}$ Even this track, "Christopher" by Canadian singer-songwriter Emm Gryner, is masculine in subject matter-its lyrics were directly inspired by Commander Hadfield and is thus named after him. At face value, then, this male-focused collection of "songs about space" has several implications.

First, the playlist depicts space exploration as a masculine activity. With the exception of Gryner's song, Hadfield's compilation contains only male voices. Literally, aside from Gryner, there are only male singers and musicians, but also in terms of agency, the playlist grants the power and knowledge of spaceflight to men alone. Additionally, the musical idioms that Hadfield chooses to include in the playlist—mostly rock n' roll, classical music, and jazz-are all historically male-dominated genres, in terms of both composition and also performance. Considering that Sally Ride, the first American woman to visit space, did not do so until 1983 (more than twenty years after the first American man, Alan Shepard, Jr., in 1961), the practice of space travel compares directly to these musical genres in that women are severely underrepresented in all. ${ }^{140}$

\footnotetext{
${ }^{138}$ The incorporation of Canadian artists is also perhaps an acknowledgement of the Canadian content requirements for radio, based on the MAPL system, which mandates that a certain percentage of musical content must be written, composed, recorded, or performed in Canada or by Canadians. For more information about the MAPL system and radio requirements, see Government of Canada, "The MAPL System - Defining a Canadian Song," Canadian Radio-television and Telecommunications Commission, August 10, 2009, https://crtc.gc.ca/eng/info_sht/r1.htm; and Government of Canada, "Radio Regulations, 1986," Justice Laws Website, January 1, 2018, https://lawslois.justice.gc.ca/eng/regulations/SOR-86-982/page-2.html\#h-7.

${ }^{139}$ It could be argued that Canadian identity is inherently masculine, which could perhaps be a reason why Hadfield chose to represent male Canadian artists almost exclusively in his playlist. For more on Canadian identity and masculinity, see Daniel Coleman, Masculine Migrations: Reading the Postcolonial Male in New Canadian Narratives (Toronto: University of Toronto Press, 1998); and Christine Ramsay, Making It Like a Man: Canadian Masculinities in Practice, Cultural Studies Series (Waterloo, Ontario: Wilfrid Laurier University Press, 2011).

${ }^{140}$ On NASA's discrimination against women, see Eric Berger, "Netflix film examines why NASA shunned women astronauts in early days," Ars Technica, April 20, 2018, https://arstechnica.com/science/2018/04/netflix-filmexamines-why-nasa-shunned-women-astronauts-in-early-days/.
} 
Further, in its androcentric focus, the playlist evokes depictions of masculinity often associated with male settlers of earlier centuries. There were of course female settlers, and while the traditional narrative suggests that these women were obedient, domesticated, and abided by traditional gender roles, more recent studies such as those undertaken by Ruth Barnes Moynihan, Susan Hodge Armitage, and Christiane Fischer Dichamp demonstrate the wide variety of colonial experiences lived by women settlers, many of whom were independent and adventurous. ${ }^{141}$ Yet, as these three scholars demonstrate, the roles of women, particularly their achievements, have often been overlooked in colonial histories, which tend to focus on men's victories in the process of settlement. ${ }^{142}$ Despite their evidence to the contrary, colonialism is still depicted as a masculine endeavor. Thus far, spaceflight has been much the same-for instance, as of 2017, only 59 of the 536 people that have visited space since cosmonaut Yuri Gagarin's initial spaceflight in 1961 have been women. ${ }^{143}$ Not only do these statistics indicate that men overwhelmingly dominate space exploration, but also that men continue to dictate the status quo of spaceflight, which likely perpetuates the gender inequality of the astronaut profession. In the same way that colonization on Earth has been depicted as masculine through androcentric histories of colonialism, then, so too is space colonization as portrayed by Hadfield's androcentric space playlist.

Indeed, historian Robert Hogg has explored the kinds of masculinity expressed by the first men on the frontiers of Queensland and British Columbia, Australia, and, as I will demonstrate, many of their expressions of masculinity are echoed in Hadfield's "Songs about

\footnotetext{
${ }^{141}$ See Ruth Barnes Moynihan, Susan H. Armitage, and Christiane Fischer Dichamp, So Much to Be Done: Women Settlers on the Mining and Ranching Frontier, Women in the West (Lincoln: University of Nebraska Press, 1990). Conversely, for depictions of white women as helpless "Indian captives" and victims, juxtaposed with disturbingly savage portrayals of Indigenous women, see Sarah Carter, Capturing Women: The Manipulation of Cultural Imagery In Canada's Prairie West (Montreal: McGill-Queen's University Press, 1997), xiv.

${ }^{142}$ Moynihan, Armitage, and Dichamp, So Much to Be Done, xi.

143 NASA, "Women in Space," NASA History Office, 2017, https://history.nasa.gov/women.html.
} 
Space" playlist. ${ }^{144}$ I also draw upon historian Karen Downing's explorations of masculinity influenced by the novel Robinson Crusoe through the years 1788-1840, which reveals the masculine undercurrents associated with exploration and colonization that are still present today in "Songs about Space." 145 In this chapter, I utilize both of these monographs to explore the messages implicit in Commander Hadfield's song choices in his "Songs about Space" Spotify playlist. My intent is to explore the marketing of the astronaut's public persona, particularly the interwovenness of his astronaut and musician personae, to ascertain the messages that the rest of us who have not explored space ourselves are supposed to take away from Hadfield's musical depictions of space. Because playlists, like their forebear, the mixed tape, are often intentional not just in the tracks included but also in their ordering, I will assess the playlist like a deliberately-crafted narrative to gain an understanding of the "story" of space that Hadfield has crafted for his listeners. But unlike mixed tapes, online playlists can also be shuffled, so I will then approach the playlist out-of-order to explore the ways that the narrative changes and to examine the implications that the shuffle feature might have on Hadfield's messages about life in space. Finally, after this careful study of the tempos, textures, modalities, timbres, and other musical content in Hadfield's playlist, I draw upon Erkki Huovinen and Anna-Kaisa Kaila's empirical approach to musical topoi to propose the idea of a space topos-one that is, according to Hadfield, overwhelmingly masculine and Western-dominated. ${ }^{146}$

\footnotetext{
${ }^{144}$ Robert Hogg, Men and Manliness on the Frontier: Queensland and British Columbia in the Mid-Nineteenth Century, Genders and Sexualities in History (New York: Palgrave MacMillan, 2012).

${ }^{145}$ Karen Downing, Restless Men: Masculinity and Robinson Crusoe, 1788-1840 (New York: Palgrave MacMillan, 2014).

${ }^{146}$ Erkki Huovinen and Anna-Kaisa Kaila, "The Semantics of Musical Topoi: An Empirical Approach," Music Perception 33, no. 2 (2015): 217-43, doi:10.1525/MP.2015.33.2.217.
} 


\section{Songs about (Men in) Space}

The narrative of Hadfield's Spotify playlist begins on a nostalgic note, with Queen's "'39," written by the band's lead guitarist Brian May. The folky acoustic guitar coupled with a bouncy walking bassline and the ethereal "ahh's" of a high falsetto voice on top of a chorus are an odd mix of sentimental and otherworldly. The song tells the story of a space crew that returns to Earth after a year in orbit, only to discover that one hundred years have passed on Earth due to Einstein's time dilation effect, and that all their loved ones are now dead. The song's tale is somewhat of a pessimistic introduction to the playlist, but to Hadfield, it perhaps represents the fear of leaving his wife, children, and entire life on Earth behind as he embarked on his initial journey to space- - likely similar to the way that the colonists of history felt as they embarked on what Hadfield referred to as their "one-way voyages." Indeed, as he was sailing toward the Australian colonies, one settler wrote that he never would have left Britain if he had known how unhappy it made him to be so far from his family. ${ }^{147}$

Hadfield's story continues with images of take-off, beginning with the original version of "Space Oddity" by David Bowie. While some have speculated that the song depicts a drug overdose, Bowie claims that it was inspired by his appreciation for the film 2001: A Space Odyssey. ${ }^{148}$ In the beginning of the popular song, Bowie states that he is "commencing countdown" as he counts backward to ten. After Bowie announces "lift off," time is suspended as an electric guitar rises eerily in pitch. The effect gradually increases in density as more rising instruments are added, sonically imitating the loss-of-gravity effect Hadfield might have experienced as he left Earth's atmosphere and, were he not strapped in, would have begun

\footnotetext{
${ }^{147}$ Downing, Restless Men, 136.

${ }^{148}$ Kelly Dickerson, “Here's what David Bowie's song 'Space Oddity' is really about," Business Insider, January 11, 2016, https://www.businessinsider.com/david-bowie-song-space-oddity-meaning-2016-1.
} 
floating away from his seat. Hadfield's own song, "Ride That Lightning" from his album Space Sessions: Songs from a Tin Can, follows next. The song is simple, fully strophic, and contains elements appropriative of African American spirituals (and imaginings of them as depicted in mistral and coon songs), including a few sections of call-and-response and a habitual dropping of final consonants as in Hadfield's pronunciation of the word "lightnin'."149 According to his commentary on the original CD, Hadfield states that the expression "ride that lightning" is meant to convey how "crazy dangerous" take-off can be, though he ultimately concludes that the danger "thrills" him, referring to space flights as "rare, unpredictable, dangerous," but worth it. ${ }^{150}$ And indeed, for British sailors and settlers, seafaring was equally as dangerous—at least, it was depicted that way in Daniel Defoe's Robinson Crusoe, through the main character's many shipwrecks and frightful encounters with what he perceived to be hostile indigenous people. The novel, which writer George Barrow credited with inspiring numerous British men to pursue colonial adventures, exemplifies this masculine quality of thirsting for danger still perpetuated by Hadfield's "Ride That Lightning." 151

The tracks that follow depict various scenes in space. The inclusion of Richard Strauss' "The Convalescent" from Also Sprach Zarathustra recalls the melodic themes from the "Sunrise" movement included in the film 2001, which builds to its dramatic climax during the opening credits as a sun rises in space from behind two large, dark, otherworldly spheres. One might imagine that Hadfield thought of this tremendous orchestral piece each time that he witnessed the sun rise from behind Earth. Other songs in the playlist evoke less peaceful images:

\footnotetext{
149 John Graziano, "The Use of Dialect in African-American Spirituals, Popular Songs, and Folk Songs," Black Music Research Journal 24, no. 2 (2004): 262-63. doi:10.2307/4145494.

${ }^{150}$ Chris Hadfield, "Ride That Lightning - Commentary," Space Sessions: Songs from a Tin Can, Spotify, https://open.spotify.com/playlist/2bMKEZzeJk1XZwVvuGmp53.

${ }^{151}$ Downing, Restless Men, 72-73.
} 
Rush's “Cygnus X-1 - Book One - the Voyage," for instance, with lyrics by the band's drummer Neil Peart, conveys the fearsome tale of a space explorer who is sucked into the black hole Cygnus X-1. Their rock n' roll musical idiom, with wailing electronic guitars and Peart's virtuosic drumming, is harsher and more violent than Strauss' orchestral medium with its "high art" connotations, further emphasizing the sinister storyline of "Cygnus X-1" and perhaps evoking feelings of fear about the many unknowns in space. Yet, Hadfield claims that he only felt true fear in space one time. He describes witnessing a meteor that "hit the Earth's atmosphere like a bomb" and realizing that "the damage would have been instant and extensive and fatal" if the meteor had hit the ISS instead - "the station would have depressurized like a pop can exploding and then each of us would have violently suffocated, tumbling in the vacuum of space." ${ }^{152}$ His comments further emphasize the inherent danger of spaceflight, evoking a masculinity which appears brave and strong in the face of peril.

Other songs in the playlist suggest the possibility of extraterrestrial life. The original Star Trek series theme by Alexander Courage, for instance, is evocative of the themes of the original Star Trek series, including social commentary about issues such as sexism and racism, imaginings of contact with various alien species, and space exploration and colonialism. Indeed, the theme, which was originally accompanied by a monologue which described space as "the final frontier," was at first entitled "Where No Man Has Gone Before." The track's ethereal flute melody is doubled by vocalized "oohs" which sound as though they were made by a Theremin, though they were actually sung by soprano Loulie Jean Norman; this Otherworldly melody is answered by horns and features a fast-moving accompaniment of electric guitar, double bass, and repetitive rhythmic percussion. In a similarly orchestral imagining of space, Gustav Holst's

\footnotetext{
${ }^{152}$ Chris Hadfield, An Astronaut's Guide to Life on Earth: What Going to Space Taught Me about Ingenuity, Determination, and Being Prepared for Anything (New York: Little, Brown and Company, 2013), 300.
} 
"Mercury, the Winged Messenger," the third movement of his suite The Planets, is also fastpaced, with rising and falling flurries of melodic patterns in the upper woodwinds, made unearthly by the accompaniment of the heavenly sounds of a harp and the tinkling of bells. One interpretation of Holst's work is that the suite was based not on the astronomy of the planets themselves but on the astrology that they represent. ${ }^{153}$ In this case, the astrological Mercury, described by Holst as the "Winged Messenger," is an imagining of Hermes, "the wily messenger of the gods," with the planet supposedly influencing traits like intelligence and communication. ${ }^{154}$ In a sense, then, the inclusion of "Mercury" could represent a curiosity and desire to make contact and to communicate with whatever is "out there" in space.

Among the many recurring themes interspersed throughout the songs in the middle of the playlist, several express profound loneliness. For instance, "Rocket Man (I Think It's Going to Be a Long, Long Time)," performed by Elton John with lyrics also by Bernie Taupin, depicts the isolation and sadness that Hadfield himself might have felt being away from his family during his time on the ISS. The song was inspired by the short story "The Rocket Man" from the 1951 collection The Illustrated Man by Ray Bradbury, about a futuristic astronaut whose job requires him to work in space for three months at a time, with only three days in between each voyage to spend home with his wife and son. Longing for Earth while in space and longing for space while on Earth, the perpetually-unsatisfied rocket man tragically dies in the end of the story when his rocket falls into the sun. The significance of the song's inclusion in Hadfield's playlist is likely twofold - the astronaut's tragic undoing in the original short story further emphasizes the theme of danger expressed throughout the playlist, while the contents of the song express a relatable

\footnotetext{
${ }^{153}$ Raymond Head, "Gustav Holst: The Planets Suite: New Light on a Famous Work," https://raymondhead.com/gustav-holst-planets.

${ }^{154}$ Tamsyn Barton, Ancient Astrology, (London: Routledge, 1994), 112.
} 
longing for home and for the companionship of the narrator's spouse and children. Similarly,

Canadian alternative-rock band Simple Plan shares sentiments about longing in their song "Astronaut," which appears later in the playlist and was written by two of the band's members, plus British musicians Julian Emery and Jim Irvin. The song's music video, released in 2011, opens with the message "Being human is the most terrible loneliness in the universe" before showing an astronaut desperately searching what appears to be space in a desperate attempt to find love. Though Hadfield has been happily married to his wife, Helene, since 1981, perhaps he could relate with certain sentiments in the song, such as feeling "deafened by the silence" in space or experiencing an eagerness to "come down" to Earth once again.

Yet, this particular musical narrative might not ring as true as Hadfield would have us think. Contrary to his depiction of space in the playlist, Hadfield did not feel lonely on the ISS:

Most people think that space flight must be lonely, being so far away from home and locked in a spaceship with a small crew for a long time. Space flight has even become a metaphor for loneliness in popular songs like "Rocket Man" and "Space Oddity." In truth, though, I was never lonely in space. I was actively working with all my crewmates daily, had near-constant radio contact with mission control centers in many countries, and the whole world was in my window, all seven billion of us there to see and wave at. And I could phone my family pretty much whenever I wanted and had a private video conference with my wife weekly. [...] What I did miss during the five months I spent off the planet was simple physical contact: the random ability to give someone a hug or kiss a loved one. Even with the nausea and weakness I felt after landing, it was great once more to be back-slapping, hugging, and kissing happily in the tumult of Earth-bound life. $^{155}$

Nonetheless, this narrative of the lonely astronaut exemplified by his chosen music hearkens back to feelings experienced by the first men on the frontier. Indeed, Robert Hogg writes about the psychological difficulties experienced by the first British colonists in parts of Australia, particularly their feelings of extreme loneliness and isolation so distressing that it sometimes led

${ }^{155}$ Hadfield, An Astronaut's Guide to Life on Earth, 304. 
to depression and alcoholism. ${ }^{156}$ Whether or not Hadfield himself experienced such difficult emotional effects while in space, his incorporation of music that perpetuates these experiences lived by colonists of the past suggest that space colonization of the future could have similarly detrimental effects for those who choose to embark on such a journey.

The theme given the most attention in Hadfield's playlist is romantic love. Indeed, Lou Reed's piano ballad "Satellite of Love" describes a tumultuous relationship with the narrator's cheating partner, while Keith Ferreira's "Fireball" is an infectiously happy remake of the theme song to the 1960s children's science-fiction television show Fireball XL5, composed by Barry Gray with lyrics by Charles Blackwell and originally sung by Don Spencer, wherein the catchy chorus repeats "My heart is a fireball, a fireball/every time I gaze into your starry eyes." The psychedelic rock band Steppenwolf also sings of love in their "Magic Carpet Ride," which opens with several seconds of distorted electronic guitar effects before breaking into an upbeat rock groove and lyrics that evoke fantastic images of Aladdin's lamp, magic carpets, and romantic love. The playlist also contains two jazzy pieces about love: Van Morrison's sensual "Moondance," and Frank Sinatra's "Fly Me to the Moon," which was written by Bart Howard and originally recorded by Kaye Ballard, but was made famous by Sinatra thanks to his version's close association with the Apollo missions ("Fly Me to the Moon" was the the first song heard on the moon via the cassette player carried by Buzz Aldrin of Apollo 11). Hadfield's emphasis on love makes sense - though he may not have felt lonely, he did admit that he missed human affection and, as Hogg has demonstrated, surviving letters from British colonists in midnineteenth-century Australia indicate a similarly intense longing for their wives. For instance, in one letter, a husband wrote that he "can think of nothing but" the family that he left behind in

\footnotetext{
${ }^{156} \mathrm{Hogg}$, Men and Manliness on the Frontier, 85.
} 
Britain. ${ }^{157}$ Numerous other letters support the old cliché that absence makes the heart grow fonder, and Hogg suggests that these sentiments of affection and yearning for one's spouse is exemplary of mid-Victorian era gender roles, wherein the husband is "the breadwinner" and the wife is "the nurturer." 158 And indeed, in the same way that British colonists supported their families and relied upon their wives for support and affection, so too have Hadfield and his wife observed these traditional marital roles throughout their marriage. ${ }^{159}$

Towards the end of the playlist is the only song performed by a female musician: Emm Gryner's "Christopher." Gryner, a Canadian singer-songwriter, worked with Hadfield on his inspace recording of "Space Oddity," writing the piano part and working with producer Joe Corcoran to incorporate the other instrumental sounds. ${ }^{160}$ In 2004, almost ten years before the "Space Oddity" collaboration, Gryner was asked to write the ballad "Christopher" to "commemorate [...] Hadfield's first free-float into space." ${ }^{161}$ Her song, which features only her voice and a slow-moving piano accompaniment, is a stark contrast to most of the rest of the playlist, not only in the feminine timbre of her voice but also in its slow tempo, sparse instrumentation, and thematic content. Indeed, the song juxtaposes life on Earth with Hadfield's space adventures, evoking desolate and bleak images of terrestrial living ("we drag race our devils to fill empty hearts"; "running for something we can't quite discern," etc.) and reverent

\footnotetext{
${ }^{157}$ Hogg, Men and Manliness on the Frontier, 93.

158 Ibid.

${ }^{159}$ Helene Hadfield raised their children, oftentimes alone while her husband traveled for work, and gave up a job at which she was a "rising star" so that she could move cities in support of her husband's budding military career. She did eventually go back to work as a realtor "because the hours were somewhat flexible," but it is clear that she ultimately sacrificed her own career to support her husband and to take up the traditional feminine role of nurturer. See Hadfield, An Astronaut's Guide to Life on Earth, 7 and 13.

${ }^{160}$ Emm Gryner, "May 12, 2013: Space Oddity in Space," The Emmbassy blog, Internet Archive Wayback Machine, https://web.archive.org/web/20130811064625/http://www.emmgryner.com/emmbassy/?q=node/861. In her description of the collaboration, Gryner writes "I came up with a piano part. i then enlisted my friend, producer and fellow Canadian Joe Corcoran to take my piano idea and Chris' vocal and blow it up into a fully produced song. Drums! mellotrons! fuzz bass! We also incorporated into the track ambient space station noises which Chris had put on his Soundcloud."

${ }^{161}$ Ibid.
} 
images of Hadfield walking in space as if he were magic, having the power to overcome the mundane tribulations of Earth life ("a place in the sky where it all disappears"; "Christopher floats to the stars"; "Christopher walks on the dark").

The final few songs in the playlist represent a return to Earth—reminiscent, perhaps, of Hadfield's own thoughts concerning his departure from the ISS and his journey home. Beginning with the humorous and educational Monty Python tune "Galaxy DNA Song" by Eric Idle and John Du Prez, the lyrics of which are comprised of many scientific facts about human biology, Earth, and the universe and conveys a sense of awe about human life, the playlist moves onto Louis Armstrong's famous "What a Wonderful World," further emphasizing wonder and reverence for Earth and the human race. Indeed, the lyrics of "What a Wonderful World," written by Bob Thiele and George David Weiss, articulate not only a profound appreciation for Earth's greenery and its cloudy blue skies, but it also depicts idealized images of harmony among Earth's people. The last two songs, in a dramatic genre shift, convey through a hard rock idiom some final images of Hadfield's experience in space. Rush's "Fly by Night," for instance, has lyrics written by Peart about his move from Canada to London, but can certainly apply to Hadfield's move from the ISS back to Earth. The song's lyrics even evoke certain colonial themes, such as in the sentiment "it's time I was king now, not just one more pawn"; to Peart, these lyrics were perhaps indicative of England's monarchial status, where one could actually be king, and the earlier British colonization of Canada, wherein human beings living in Canada found themselves as figurative pawns in the game of colonialism. However, considering the song's inclusion in Hadfield's "Songs about Space" playlist, these lyrics could be reimagined to represent the colonization of space or other planets, where one could reign over previously uninhabited environments or perhaps over conquered indigenous extraterrestrial subjects, should 
they exist. The playlist then closes with Prism's "Spaceship Superstar," a fun, upbeat song which imagines the narrator as an intergalactic Rockstar who plays gigs on various planets each night with his a "solar-powered laser beam guitar." "Spaceship Superstar" is, in a sense, a return to the nostalgia that began the playlist, considering that this song was used as the wakeup song for the crew of the space shuttle Discovery on March 6, 2011, the last day of collaboration between the crew of the shuttle and the ISS crew before the shuttle returned to Earth. Though Hadfield was not a member of either crew at the time, the bright rock n' roll tune nonetheless likely represents the astronaut's final hurrah in space before returning to his home planet.

The story told by Hadfield's "Songs about Space" playlist, from the initial take-off to the spaceman's return to Earth, is uncannily reminiscent of the experiences of British settlers in the late eighteenth and early nineteenth centuries, as I hope to have demonstrated in this analysis. His playlist tells a dramatic story of space exploration that is filled with danger, isolation, and longing, and simultaneously reinforces the ideals of colonial masculinity and Victorian-era gender roles. Though perhaps Hadfield's own lived experiences deviated from these tropes in some ways, his playlist nonetheless reinforces and strengthens these images of masculinity and colonization often associated with space exploration. In this way, Hadfield implies to listeners who may not know the details of his personal experiences that their ideas about being an astronaut — the loneliness, the longing, and the masculinity — are indeed accurate and that these songs exemplify his own time in space.

\section{Songs about (Men in) Space: Readings on Shuffle}

Shuffling Hadfield's “Songs about Space” Spotify playlist allows listeners to engage with the same content in a non-linear way, thereby generating new narratives. On the shuffle setting, 
the songs continue to convey similar themes of isolation, longing, love, masculinity, and colonization, though the playlist's reordering could be interpreted to tell a slightly different story (see figure 1 for a comparison of the playlist's original form and two shuffled variations).

For instance, the first shuffling brought Rush's "Fly by Night" into the foregroundrather than a nostalgic and somber beginning as in the original order, this new version offers an upbeat, optimistic opening about "leaving [one's] homeland" for a "new life ahead" amongst the

\begin{tabular}{|c|c|c|c|}
\hline Position & Original Playlist & Shuffled Playlist 1 & Shuffled Playlist 2 \\
\hline 1. & “"39” & "Fly by Night" & Star Trek Original Theme \\
\hline 2. & "Space Oddity" & "“39" & "Fly Me to the Moon" \\
\hline 3. & "Ride That Lightning" & "Mercury" & "Satellite of Love" \\
\hline 4. & "The Convalescent" & "Fireball" & "Rocket Man" \\
\hline 5. & "Rocket Man" & "The Convalescent" & "Moondance" \\
\hline 6. & "Satellite of Love" & "Galaxy DNA Song” & "The Convalescent" \\
\hline 7. & "Cygnus X-1" & "Rocket Man" & "Spaceship Superstar" \\
\hline 8. & "Mercury" & "Space Oddity" & "Astronaut" \\
\hline 9. & "Fireball" & "Cygnus X-1" & "Space Oddity" \\
\hline 10. & "Magic Carpet Ride" & "Magic Carpet Ride" & "Ride that Lightning" \\
\hline 11. & "Moondance" & "Ride That Lightning" & "“639" \\
\hline 12. & "Fly Me to the Moon" & "Astronaut" & "Cygnus X-1" \\
\hline 13. & Star Trek Original Theme & Star Trek Original Theme & "Galaxy DNA Song" \\
\hline 14. & "Christopher" & "Moondance" & "Fly by Night" \\
\hline 15. & "Astronaut" & "Fly Me to the Moon" & "Fireball" \\
\hline 16. & "Galaxy DNA Song" & "Spaceship Superstar" & "Mercury" \\
\hline 17. & "What a Wonderful World" & "Satellite of Love" & "Magic Carpet Ride" \\
\hline 18. & "Fly by Night" & "Christopher" & "Christopher" \\
\hline 19. & "Spaceship Superstar" & & \\
\hline
\end{tabular}

Figure 1. A list of tracks in Hadfield's "Songs about Space" playlist, in their original ordering and then in a shuffled order, randomized by Spotify's shuffle feature. ${ }^{162}$

162 The link to the version of Louis Armstrong's "What a Wonderful World" contained in Hadfield's playlist does not work (as of writing on January 27, 2019), so this song was unfortunately not represented in the shuffle version. 
stars, to the tune of a wailing electric guitar and masterful rock n' roll drums. This new imagining evokes similar feelings of the irresistible compulsion for and the thrill of exploration as described by British sailors who yearned for a life at sea. ${ }^{163}$

Coincidentally, both random shuffles of the playlist closed significantly with Emm Gryner's "Christopher." To have the lone female artist's song at the very end in this version further separates her from her male counterparts on the playlist and, in a sense, emphasizes the role of women in the colonial period. For instance, in Robinson Crusoe's treatment of his family, his adventurous travels were his top priority, while his wife remained an afterthought. ${ }^{164}$ Meanwhile, she was expected to raise and care for the children and the homestead on her own, while also being supportive of her husband's freedom to leave her at his whim. In some ways, "Christopher" reads similarly, as if it were written by a devoted lover that has been left behindher world on Earth is bleak and empty, while her heroic explorer is larger-than-life in an idealized, seemingly magical place without pain. In this reading, the left-behind narrator longs not for the explorer per say but for the freedom that he exercises in his journey, a freedom unattainable to her as a woman. In a different reading, the song's position at the end of the playlist serves as a conclusion of glory and wonder in the story of Commander Hadfield's space adventures, through the admiring eyes of an uninvolved observer-equivalent to a book's afterword section, perhaps, written by another author with personal ties to the subject at hand (in Gryner's case, this might be their collaboration on "Space Oddity"). Like any appropriate afterword, Gryner's conclusion paints Hadfield and his space adventures with reverent wonder, marveling at his accomplishments and reinforcing his masculine power of spaceflight. Her

\footnotetext{
163 Downing, Restless Men, 73.

${ }^{164}$ Ibid., 149.
} 
admiration portrays Hadfield with the same colonial heroism that has traditionally been ascribed to other male settlers in older historiographies. ${ }^{165}$

The second random shuffling also reveals a new narrative beginning. For instance, this version of Hadfield's playlist opens with the original Star Trek theme, bringing to mind images of Captain Kirk and his multiracial crew on the U.S.S. Enterprise as they soar through the galaxy on warp speed. This intermingling of aliens and humans at the start of the playlist insinuates that Hadfield's belief in the existence of intelligent extraterrestrial life is a central part of his space journey due to its new prominence at the very beginning of the playlist. One might even imagine a science-fiction-like story in which Hadfield and his crewmates on the ISS make contact with an alien race, as the Star Fleet crew so often did on the U.S.S. Enterprise.

The fact that the Star Trek theme and its extraterrestrial connotations are immediately followed by the love song "Fly Me to the Moon" in this second shuffling could also be construed to represent a romantic human-alien love story, perhaps similar to the one depicted between the Star Trek characters Spock and Uhura in the more recent J.J. Abrams adaptations of the franchise since 2009. Indeed, exotic women have traditionally been hypersexualized. ${ }^{166}$ However, as we know from what is purported to be the most famous account of a "love story" in colonial timesthat of Pocahontas - romance between colonists and indigenous people is not always as picturesque as Disney fairy tales would have us believe. Indeed, contrary to the popular children's cartoon, the real Pocahontas was held in captivity, convinced that her father (the Chief Powhatan Wahunsenaca) did not love her because he did not pay her (impossible) ransom, and made to marry not John Smith but another English settler named John Rolfe. ${ }^{167}$ It is possible that

\footnotetext{
${ }^{165}$ See more about men being the "heroic protector" of white settler women in Carter, Capturing Women, xiv.

166 Ania Loomba, Colonialism/Postcolonialism (London: Routledge, 2015), 125.

${ }^{167}$ Linwood Custalow and Angela L Daniel, The True Story of Pocahontas: The Other Side of History: From the Sacred History of the Mattaponi Reservation People (Golden, Colorado: Fulcrum, 2007), 86.
} 
these unfortunate circumstances could repeat themselves in space between astronaut-colonists and extraterrestrials indigenous to other planets, and the fact that "Fly Me to the Moon" is then followed by Lou Reed's “Satellite of Love," an anti-love story about painful conflict with one's romantic partner, suggests that this human-alien "romance" does indeed end in pain and suffering just as did Pocahontas'.

There are numerous other possibilities for the reinterpretation of Hadfield's "Songs about Space" playlist on shuffle. Though I have shown only a few examples here, I hope to have illustrated the prevalence of the colonial narrative in Hadfield's playlist — no matter where individual songs are positioned, the messages tend to evoke similar depictions of the heroism, power, and sense of adventure in the male colonist, the loneliness of the frontier, and the heterosexual desire for the companionship and affection of women, both those left back in the homeland and also those exotic women of the new frontier.

\section{Conclusion: The Genesis of a Space Topos}

From the various themes and idioms present in Hadfield's "Songs about Space" playlist, it is possible to extract a space topos, or a set of characteristics that can typify space music more generally. Erkki Huovinen and Anna-Kaisa Kaila have defined musical topoi as "a set of musical entities, as delimited and coherently furnished with meaning by consistent trends of shared extramusical associations in a significant majority of listener population." 168 And indeed, while the average music listener might not have initially associated some of these songs with space, the fact that Hadfield created such a playlist for his many social media followers automatically creates an extramusical association in his listener population due to his own labeling and

\footnotetext{
${ }^{168}$ Huovinen and Kaila, “The Semantics of Musical Topoi: An Empirical Approach,” 220.
} 
description of these songs as being "about space" and reminiscent of his time on the ISS. Huovinen and Kaila propose a series of steps in developing a topos, which involves first determining the perceived mood and situation evoked by the music, then from these creating semantic fields, or groups of words that describe a specific subject, which can then be interpreted as topoi. ${ }^{169}$

I have already determined several moods and themes that might be interpreted from the songs contained in Hadfield's playlist and some of their musical characteristics. For instance, several of the songs convey an upbeat excitement, often exemplified by a moderate to quick tempo, as in Rush's "Fly by Night" or Hadfield's own "Ride That Lightning." Indeed, with the exception of a few, including Gryner's "Christopher" and Armstrong's "What a Wonderful World," a medium to fast tempo remains consistent, implying that space is associated with a certain kind of upbeat energy, be it exhilaration, anxiety, or a sense of adventure.

All songs in the playlist bear a homophonic texture - a melody plus an accompanimentand most, but not all songs in the playlist, feature certain kinds of timbres. Many songs, for instance, draw upon electronic timbres - the electric guitars of 1980s rock n' roll, especially, or the low synthesizer drone in the beginning of Bowie's "Space Oddity"-and some sort of unpitched, repetitive rhythmic element like drums. Even more songs feature piano, including "Ride That Lightning," "Rocket Man (I Think Its Going to Be a Long, Long Time)," "Satellite of Love," "Moondance," "Fly Me to the Moon," "Christopher," "Astronaut," and "What a Wonderful World." Fewer songs bear acoustic guitar or the orchestral timbres of strings or wind instruments, though these are present as well. However, the majority of the included songs do feature vocals which often tell a short narrative story and contain a memorable, singable chorus.

${ }^{169}$ Ibid. 
It is crucial to remember, of course, that these vocals are, almost without exception, male. Additionally, these vocals are, entirely without exception, in English.

What we can surmise from these elements are patterns that, aside from a few outliers, represent the topos of space from an astronaut's perspective: a moderate to fast tempo, a homophonic texture, and an idiom that is heavily influenced by Western popular music, bearing timbres that often combine piano, electronic effects, and a vocal narrative delivered by a male singer that reiterates age-old themes of discovery, danger, isolation, longing, and the masculinity associated with colonialism. Significant to this space topos and its colonial implications is its emphasis on the West; it bears both the West's verbal and musical language, and it ignores other cultures and musical traditions. There are no evocations of Russian folk music, for instance, despite the fact that the cosmonauts were the first to fly in space; there are no depictions of the Other, either, like those represented in Jóhann Jóhannson's score for Arrival, or in Terry Riley's Sun Rings - rather, this space topos asserts dominance in the same way that has been done historically: the voices of the colonized are erased, while the colonist writes the history books.

What does this playlist, and the space topos that it creates, say about how Commander Hadfield wants us to perceive space? The astronaut's incorporation of primarily popular music, particularly that of rock n' roll, could perhaps contain a message intended for the primarily young people who regularly access Spotify and use the platform to discover new music. His music choices might convey to this young audience that spaceflight is exciting, relatable, or even hip, perhaps serving as a recruiting effort to inspire more Canadian astronauts like Hadfield. Coupled with his social media presence and efforts to educate the public about his experiences in space, this conclusion is entirely plausible - this Spotify playlist could, in part, serve as another 
method for Hadfield to garner excitement and support for continued spaceflight efforts, despite his own retirement.

Yet, ultimately, this depiction of space through Hadfield's playlist glorifies the heroic astronaut / colonist, who sacrifices time away from his loved ones, endures the loneliness of their absence, and bravely faces danger for the sake of human discovery. In many ways, it retells the history of the West's colonial conquests in a contemporary idiom, evoking many of the same images and feelings that we often associate with male-dominated colonial histories. The playlist also implies that these sorts of conquests are an inevitable aspect of the human experience, and conveniently ignores the harm that they cause to indigenous life and lands, focusing only on the ways that the conquests affect the colonists themselves. Perhaps most broadly, the playlist asserts and reinforces a notion of dominance - the dominance of the patriarchal West, who are the colonists of old and, should Hadfield get his wish, will be the colonists of the future in space. 


\section{Conclusions: Postcolonial Earth, Precolonial Space}

Recall from my introduction that the late physicist and cosmologist Stephen Hawking once pessimistically expressed, "we only have to look at ourselves to see how intelligent [alien] life might develop into something we wouldn't want to meet.” Indeed, as I have demonstrated through my explorations of the musical score to Denis Villeneuve's 2016 film Arrival, Terry Riley and the Kronos Quartet's 2002 string piece Sun Rings, and Commander Chris Hadfield's "Songs About Space" Spotify playlist, our musical conceptions of the extraterrestrial Other are often negative, whether due to fear or due to lingering colonialist ideologies and exoticist beliefs. Indeed, Hawking's pessimism stems from the shame of our own history of colonial conquesthis reference to the poor treatment of Native Americans in the first part of the quote illustrates the lasting impact of the atrocities committed against indigenous people, and the potential for similar devastations to occur in our future dealings with intelligent extraterrestrial life. Indeed, while much of Earth might be in a postcolonial state, currently coming to terms with the aftermath of colonialism (or, for the privileged, selectively forgetting that it ever happened, as Leela Gandhi suggests), space has been, for the most part, unexplored, undiscovered, and unconquered. ${ }^{170}$ But with SpaceX's and MarsOne's imminent plans to colonize Mars in the coming decade, it is only a matter of time until this precolonial space becomes a colonized one similar to our postcolonial Earth and its hybridized cultures and musical practices.

\footnotetext{
${ }^{170}$ Gandhi discusses the "will-to-forget” our colonial past. See Leela Gandhi, Postcolonial Theory: A Critical Introduction, $2^{\text {nd }}$ edition (New York: Columbia University Press, 2018), 4.
} 


\section{Hybridity and Music}

As Mina Yang points out in her explorations of classical music's influence on East Asian musicians, "it is no longer possible to speak of culture as monolithic or pure." ${ }^{171}$ Indeed, though my thesis has drawn upon the historical circumstances of past colonialism and related indigenous musical traditions, such as my brief look to the appropriation of Hindustani classical music in Terry Riley's Sun Rings, I by no means intend to paint any particular culture, musical tradition, or colonial experience as monolithic. Each colonial situation is vastly different, and likewise the experiences of each individual within colonial situations are exceptionally varied. For instance, Yang demonstrates the detrimental effects of colonialism in nineteenth-century Japan when indigenous musical practices were nearly eradicated in favor of Western classical music; yet, at the same time, many in Japan received the West's music, notational practices, and instruments with large amounts of enthusiasm, dispelling the notion that the each aspect or experience of colonialism is inherently unwelcome. ${ }^{172}$ While the lasting harm caused by colonial practices has been colossal, it would be invalidating to the experiences of many to suggest that the colonial encounter is unequivocal.

Cultural exchanges, and the intermingling of musical traditions, has been a natural consequence of colonialism that has inevitably changed every culture and music that it has touched (though it is crucial to note that these changes are often, but not always, a result of imposition on the part of the colonized and theft on the part of the colonists). In spaces consisting of both colonized and colonizer, new music resulting from these cultural exchanges have been embraced by many as innovative and forward thinking. Others, however-including my own

\footnotetext{
${ }^{171}$ Mina Yang, Planet Beethoven: Classical Music at the Turn of the Millennium (Wesleyan University Press, 2014), 68.

${ }^{172}$ Ibid., 69-70.
} 
writing in this thesis - have drawn attention to the problematic implications of inappropriate borrowings taken out of context. These borrowings are especially detrimental when they appropriate music that has significant cultural meaning in religious practices or other deeply meaningful areas. Additionally, as I have shown in this document, the intermingling of musical practices can also be harmful when used to create inauthentic or exotic depictions of those from other cultures, because these musical misrepresentations only perpetuate damaging stereotypes and feelings of Otherness towards the culture from whence the musical practices are borrowed.

Indeed, the twentieth and twenty-first centuries have been rife with political Othering and its negative consequences. For instance, in the Origins of Totalitarianism, Hannah Arendt posits that propaganda and terror are two key strategies of the Nazi movement and of totalitarian government. ${ }^{173}$ But to expand on her work on antisemitism and Nazism, the past several decades have also seen these strategies employed across a myriad of places and issues. The Srebrenica massacre of 1995, for example, was the result of strife in Bosnia between Muslim Bosniaks and Orthodox Serbs, the former of whom was subjected to terror and violence in a 1992 ethnic cleansing campaign by the latter and were eventually the victims of genocide in Srebrenica, an area of Bosnia that was supposed to have been a UN safe zone. Similarly, in Rwanda around this same time period, up to a million Rwandans were murdered by the Hutu people, who were warring with the Tutsi victims. This genocide was, again, the result of an ethic Othering that occurred when the Tutsi refugees that fled to Uganda were portrayed as alien and evil. We continue to see this harmful Othering of non-Western cultures in recent American politics.

\footnotetext{
${ }^{173}$ Hannah Arendt, The Origins of Totalitarianism (New York: Harcourt Brace Jovanovich, 1979), 341-351.
} 


\section{The Trump Administration, American Nationalism, and the Space Force}

President Trump has done his fair share of perpetuating negative stereotypes (and in some cases, instigating them) through his own propaganda. One need not look further than his treatment of his fellow politicians to see this rhetoric in action. For instance, after Massachusetts senator Elizabeth Warren announced her presidential campaign in February 2019, Trump took to his favorite social media platform to taunt her, writing "Today Elizabeth Warren, sometimes referred to by me as Pocahontas, joined the race for President. [...] See you on the campaign TRAIL, Liz!"'174 His offensive name-calling strategy in consistently referring to Warren as Pocahontas not only invalidates our former and current atrocious treatment of Native Americans but also Others the senator in an attempt to weaken her position and depict her as vastly different from Trump and his base. ${ }^{175}$ His horrendous allusion to the Trail of Tears (emphasized by his choice of capital letters in the word "TRAIL") makes light of the historic forced march of Cherokee people that resulted in thousands of deaths via hunger and disease and presents as a threat to Warren on the campaign trail. His comments to and about Warren represent but one small facet of his widespread social media propaganda that consistently paints non-white, nonAmerican, non-Christian people as Other.

Additionally, as evidenced by his “America First" slogan, which appeared again in 2018 as the title of a foreign policy budget plan prioritizing border security and military spending, Trump maintains a conspicuously nationalist attitude. The slogan problematically borrows from

\footnotetext{
${ }^{174}$ Donald J. Trump (@realDonaldTrump), “Today Elizabeth Warren, sometimes referred to by me as Pocahontas, joined the race for President. Will she run as our first Native American presidential candidate, or has she decided that after 32 years, this is not playing so well anymore? See you on the campaign TRAIL, Liz!" Twitter, February 9 , 2019, 2:54pm, https://twitter.com/realDonaldTrump/status/1094368870415110145.

${ }^{175}$ Warren's claim that she has Cherokee DNA is highly controversial, having been contested by Cherokee tribe leaders and ridiculed by Trump's supporters (the latter of which serves as evidence that his propaganda works). See Astread W. Herndon, "Elizabeth Warren Stands by DNA Test. But Around her, Worries Abound," New York Times, December 6, 2018, https://www.nytimes.com/2018/12/06/us/politics/elizabeth-warren-dna-test-2020.html.
} 
the America First Committee established during World War II, an anti-war organization that espoused anti-Semitic rhetoric. Trump himself has been accused of anti-Semitism after the White House's failure to acknowledge the six million Jews that were killed during the Holocaust on International Holocaust Remembrance Day in 2017. A spokesperson purported to avoid explicitly mentioning the Jewish victims because the administration is "incredibly inclusive" and wanted to take "into account all of those who suffered." 176 Instead, their vague statement represented a disturbing failure to denounce anti-Semitic ideology. In October 2018, a horrific mass murder in a Jewish synagogue in Pittsburgh, Pennsylvania, motivated by anti-Semitism, illustrated why it is imperative that the leader of our country explicitly condemn bigoted ideologies and actions. ${ }^{177}$ And though the president has taken action more recently to honor Jewish survivors of the Holocaust, including one man who was both a prisoner at Dachau concentration camp as well as a member of the Pittsburgh synagogue where the horrifying massacre occurred, these actions are not nearly enough. ${ }^{178}$ Indeed, according to the spokesperson for the Jewish organization HIAS, history shows that Trump's foreign policies are inherently problematic: "stories of Holocaust survivors are reminders that we should welcome the stranger and protect the refugee. Making the U.S. great means upholding our commitment to international law and asylum seekers."179

\footnotetext{
176 Jake Tapper, "WH: No Mention of Jews on Holocaust Remembrance Day Because Others were Killed Too," CNN, February 2, 2017, https://www.cnn.com/2017/01/28/politics/white-house-holocaust-memorial-day/index.html. For the original statement, see "Statement by the President on International Holocaust Remembrance Day," whitehouse.gov, Statements and Releases, January 27, 2017, https://www.whitehouse.gov/briefingsstatements/statement-president-international-holocaust-remembrance-day/. ${ }^{177}$ Campbell Robertson, Christopher Mele, and Sabrina Tavernise, "11 Killed in Synagogue Massacre; Suspected Charged with 29 Counts,” New York Times, October 27, 2018, https://www.nytimes.com/2018/10/27/us/activeshooter-pittsburgh-synagogue-shooting.html.

${ }^{178}$ Michelle Boorstein, "Trump Mentioned Two Holocaust Survivors During the State of the Union - Including One Who Also Survived the Pittsburgh Synagogue Shooting," Washington Post, February 5, 2019, https://www.washingtonpost.com/religion/2019/02/06/president-trump-just-mentioned-holocaust-survivor-whosurvived-pittsburgh-synagogue-shooting/?utm_term=.8932a3625a45.

${ }^{179}$ Ibid.
} 
Indeed, Jewish Americans are not the only victims of Trump's policies and failure to denounce bigotry. The fates of Syrian refugees at the height of the Syrian Civil War and the asylum-seekers at the Mexican border have remained prominent sources of controversy throughout Trump's tenure. His tweets about the Syrian refugees began prior to the start of his presidency, expressing disturbing sentiments that the "refugees from Syria $[\ldots]$ pouring into our great country $[\ldots]$ could be ISIS" and that we must "protect America" from them. ${ }^{180}$ This fearmongering about the dangerous Syrian immigrants who, in reality, are desperate to escape the horror and trauma of the war at their doorsteps, is reminiscent of the foreboding musical idiom in Jóhann Jóhannsson's score to Arrival. Jóhannsson's work draws upon exotic musical tropes and eerie low-register effects to suggest that the peaceful extraterrestrial visitors should be feared and turned away by force if necessary, serving as a kind of sonic translation of Trump's own statements about the supposedly menacing Syrian refugees.

Likewise, the president's comments about the asylum-seekers at the southern border of the United States have been equally reinforcing of damaging stereotypes. In instances of fearmongering similar to his belligerent generalization that Syrian refugees are members of ISIS, Trump has claimed that these immigrants are "criminals, drug dealers, [and] rapists" who bring "tremendous crime." 181 Many of the president's supporters appear to agree with these outlandishly false accusations as evidenced by the continued raucous chanting to "build that

\footnotetext{
${ }^{180}$ Donald J. Trump (@realDonaldTrump), "Refugees from Syria are now pouring into our great country. Who knows who they are - some could be ISIS. Is our president insane?" Twitter, November 17, 2015, 5:54am, https://twitter.com/realdonaldtrump/status/666615398574530560. See also Donald J. Trump (@ realDonaldTrump), "Crooked Hillary wants a radical $500 \%$ increase in Syrian refugees. We can't allow this. Time to get smart and protect America!” Twitter, May 22, 2016, 12:38pm, https://twitter.com/realdonaldtrump/status/734468447829004288.

${ }^{181}$ Hunter Walker, "Donald Trump Just Released an Epic Statement Raging Against Mexican Immigrants and 'Disease,"” Business Insider, July 16, 2015, https://www.businessinsider.com/donald-trumps-epic-statement-onmexico-2015-7\#ixzz3fF897ElH. See also Colin Campbell, "Trump: 'I Use the Word Rape and All of a Sudden Everyone Goes Crazy,"” Business Insider, July 6, 2015, https://www.businessinsider.com/trump-i-use-the-wordrape-and-all-of-a-sudden-everyone-goes-crazy-2015-7.
} 
wall" at Trump rallies, in reference to the border security wall promised by the president during his candidacy that would separate the United States from Mexico. Disturbingly, middle school bullies have also used the "build that wall" slogan to torment classmates of color, particularly in areas where Trump votes were highest. ${ }^{182}$ An even more horrendous consequence of Trump's discriminatory rhetoric has been the tragic separation of parents and children at the border. While parents were detained for entering the United States illegally, thousands of their children were sent to shelters, many of which had a known history of child abuse and allegedly injected the migrant children with sedatives by force. ${ }^{183}$ Indeed, due to lack of adequate facilities and supplies, two children have even died at the shelters. ${ }^{184}$ Shockingly, in January 2019 the Trump administration admitted that they did not have an accurate total number of the thousands of children that have been separated from their parents, which is grossly negligent. Some academic circles have likened the situation to that of the Japanese Americans who were held in inhumane internment camps during World War II. ${ }^{185}$ This conclusion is even more disturbing when one

\footnotetext{
182 Francis L. Huang and Dewey G. Cornell, "School Teasing and Bullying After the Presidential Election," Educational Researcher (January 2019), doi: 10.3102/0013189X18820291.

${ }^{183}$ For reports about drugs used in the shelters, see Matt Smith and Aura Bogado, "Immigrant Children Forcibly Injected with Drugs at Texas Shelter, Lawsuit Claims,” The Texas Tribune, June 20, 2018, https://www.texastribune.org/2018/06/20/immigrant-children-forcibly-injected-drugs-lawsuit-claims/; and, Megan Cerullo, "Government-Funded Treatment Center Forcibly Injected Immigrant Kids with Drugs: Legal Filings," The San Diego Union-Tribune, June 20, 2018, https://www.sandiegouniontribune.com/ny-news-drugging-immigrantchildren-20180620-story.html. For reports on the facilities' history of child abuse, see Aura Bogado, Patrick Michels, Vanessa Swales, and Edgar Walters, "Migrant Children Coming to the US are Being Sent to Shelters with Histories of Child Abuse Allegations," PRI, Reveal, June 20, 2018, https://www.pri.org/stories/2018-06-20/migrantchildren-coming-us-are-being-sent-shelters-histories-child-abuse; and Molly Olmstead, "Report: Nearly Half of Funding for Child Migrant Care Went to Shelters with Histories of Abuse,” Slate, June 20, 2018, https://slate.com/news-and-politics/2018/06/report-finds-long-history-of-abuse-in-child-migrant-shelters.html. ${ }_{184}$ Doug Stanglin, "Two Children have Died in US Border Custody This Month. Before That, None in a Decade. Why Now?" USA Today, December 27, 2018, https://www.usatoday.com/story/news/2018/12/27/us-mexico-borderdeaths-guatemalan-boy-girl-deaths-rare-occurrence/2420568002/.

${ }_{185}$ Chris Quintana, Teghan Simonton, and Megan Zahneis, "College Leaders and Professors Ramp Up Protest of Trump's Family-Separation Policy,” The Chronicle of Higher Education, June 19, 2018, https://www.chronicle.com/article/College-LeadersProfessors/243714.
} 
recalls that Arendt suggests in The Origins of Totalitarianism that concentration camps are a totalitarian "rule of terror [...] brought to perfection." 186

Despite the damaging rhetoric and inhumane treatment of these migrants, most are fleeing from violence and tragedy in Central America (not Mexico, despite the president's assertions) and seeking asylum in the United States, which is legal and a stark contrast to the allegations of illegal migration so often articulated by the administration and its supporters. Former Attorney General Jeff Sessions stated that, though he has "no doubt" that the migrants are fleeing violence, "we cannot take everyone on this planet who is in a difficult situation." 187 Perhaps his comment bears some truth, but it certainly does not mean that the solution is to villainize the migrants, tear their families apart, and subject them to abuse. Trump's harmful accusations that the migrants are criminals seems to be an attempt to justify their cruel treatment and has clearly only worsened the divide that separates his American supporters from the Mexican- and Central American-Other, similar to his perpetuation of the destructive stereotypes that paint the Syrian refugee and Jewish American as Other. His destructive rhetoric and treatment of these outsiders is exemplary of Arendt's ideas about propaganda and terror in totalitarian politics.

In his nationalist desire to protect the United States from outsiders, Trump has turned not only to the construction of a wall but also to the stars. His plans for the Space Force, a fifth branch of the U.S. military that would comprise "an elite group of war fighters specializing in the domain of space," were met with much enthusiasm from the president's supporters, despite the

\footnotetext{
186 Arendt, The Origins of Totalitarianism, 344.

187 Sari Horowitz and Maria Sacchetti, "Sessions Vows to Prosecute All Illegal Border Crossers and Separate Children from Their Parents," Washington Post, May 7, 2018, https://www.washingtonpost.com/world/nationalsecurity/sessions-says-justice-dept-will-prosecute-every-person-who-crosses-borderunlawfully/2018/05/07/e1312b7e-5216-11e8-9c91-

7dab596e8252_story.html?noredirect=on\&utm_term=.f705adc1ff78.
} 
fact that a portion of the U.S. Air Force is already monitoring space. ${ }^{188}$ Although Trump supporters are filled with fervor about the new military organization, when comedian-journalist Michael Kosta interviewed supporters about the Space Force at a Trump rally in the summer of 2018, none of them could articulate what exactly the Space Force was. Some suggested that the branch would protect the United States from "space ISIS," while others maintained that "we would be wasting a lot of dollars" to create the Space Force but that the expenditure will be worth it since the Space Force is "just going to be cool." 189 Trump's vague plans to defend the United States in space are not his only space-related aspirations, however; the president also hopes to fund a NASA trip to Mars as soon as possible. ${ }^{190}$ Whether or not these space endeavors actually happen during the president's remaining tenure, Trump's insistence on establishing U.S. dominance in space hearkens back to the similar nationalist goals of the Space Race of the midtwentieth century. His plans also demonstrate increasing anxiety about the possibility of warfare in space, whether instigated by extraterrestrial forces or by other space-travelling humans from outside of the United States.

\section{Beyond Earth: Future Directions}

Based on Trump's hurry to be the first president to send humans to Mars and his discriminatory rhetoric towards the terrestrial Other, one can only imagine what might happen if we were to make contact with intelligent extraterrestrial life in the near future. Would they be

\footnotetext{
${ }^{188}$ Erin Durkin, “Space Force: All You Need to Know about Trump's Bold New Interstellar Plan," The Guardian, August 10, 2018, https://www.theguardian.com/us-news/2018/aug/10/space-force-everything-you-need-to-know. 189 The Daily Show with Trevor Noah, season 23 episode 136, “In Trump's Universe, Everyone Loves 'Space Force," directed by Paul Pennolino, interview by Michael Kosta, aired on June 26, 2018, on Comedy Central, https://www.youtube.com/watch?v=LYQX-BPUqN4.

${ }_{190}$ Olivia Nuzzi, "How Trump Offered NASA Unlimited Funding to Go to Mars in His First Term," Intelligencer, January 22, 2019, http://nymag.com/intelligencer/2019/01/trump-offered-nasa-unlimited-funding-to-go-to-mars-by2020.html.
} 
villainized and labeled as dangerous outsiders like the Syrian refugees and the asylum-seekers? Would we instigate deadly interplanetary war without fully understanding them like in Arrival? If they have musical cultures, would we misrepresent them the way that Terry Riley misrepresents non-Western music in Sun Rings? Would they eventually be written out of colonial histories the way that women and non-Westerners have been excluded from Commander Hadfield's Spotify playlist? If we change nothing politically and socially on Earth before making contact, it is safe to assume that the answer to all of these questions is "yes," whether or not the extraterrestrials come in peace. Our Othering of that which is different is prevalent and dangerous. In this thesis, I have demonstrated that it exists sonically in movies, Western art music, and pop music, but its existence can also be found in numerous other places, including in the very ideologies of the United States government.

Musical depictions of the Other only solidify these problematic ways of thinking and interacting. While this thesis was not by any means intended to be a comprehensive survey of sonic depictions of space, the case studies with which I have engaged have illustrated that these biased worldviews have been expressed musically to represent space and extraterrestrial life by composers, performers, and even astronauts alike. These Othering representations are premature, considering that we have not yet discovered the existence of intelligent life on other planets; and yet, in this way, they foretell the future, because we will inevitably approach any life that does exist in the same suspicious and violent way that the settlers approached indigenous people and the Trump administration approaches immigrants of color. And while future musicological research that draws upon postcolonial studies (or perhaps even my own idea of a space topos) could possibly reveal more insights into the ways in which composers and musicians musically represent the extraterrestrial Other, it is even more urgent that we begin to amend and learn from 
our former treatment of non-Western indigenous groups before we find history repeating itself among the stars. 


\section{Works Cited}

Alexander, Michelle. The New Jim Crow: Mass Incarceration in the Age of Colorblindness. New York: New Press, 2010.

Arendt, Hannah. The Origins of Totalitarianism. New York: Harcourt Brace Jovanovich, 1979.

Barton, Tamsyn. Ancient Astrology. London: Routledge, 1994.

BBC 5 Live. “Chris Hadfield: 'Odds are Enormous' That Alien Life Exists.” Uploaded July 27, 2015. https://youtu.be/GVaxCrdWZDc.

Bellman, Jonathan. "Musical Voyages and Their Baggage: Orientalism in Music and Critical Musicology." Musical Quarterly 94 (2011): 417-438.

Bellman, Jonathan, ed. The Exotic in Western Music. Boston: Northeastern University Press, 1998.

Bennett, David. "Postmodern Eclecticism and the World Music Debate: The Politics of the Kronos Quartet." Context 29-30 (2005), 5-15.

Berger, Eric. "Netflix Film Examines Why NASA Shunned Women Astronauts in Early Days." Ars Technica. April 20, 2018. https://arstechnica.com/science/2018/04/netflix-filmexamines-why-nasa-shunned-women-astronauts-in-early-days/.

. "To Almost No One's Surprise, Mars One is Done [Updated]." Ars Technica.

February 11, 2019. https://arstechnica.com/science/2019/02/to-almost-no-ones-surprisemars-one-is-done/.

Beta, Andy. "Annihilation: Geoff Barrow and Ben Salisbury Talk Its Haunting Score.” Rolling Stone. March 14, 2018. https://www.rollingstone.com/music/music-features/annihilationgeoff-barrow-and-ben-salisbury-talk-its-haunting-score-197947/.

Bhabha, Homi K. The Location of Culture. New York: Routledge, 1994.

Bin Laden, Osama. "Bin Laden's Fatwa.” PBS Online News Hour via Internet Archive Wayback Machine. October 31, 2001. https://web.archive.org/web/20011031024057/ http://www.pbs.org/newshour/terrorism/international/fatwa_1996.html.

Bloechl, Olivia A. Native American Song at the Frontiers of Early Modern Music. New York: Cambridge University Press, 2008.

Bogado, Aura, Patrick Michels, Vanessa Swales, and Edgar Walters. "Migrant Children Coming to the US are Being Sent to Shelters with Histories of Child Abuse Allegations." PRI.

Reveal. June 20, 2018. https://www.pri.org/stories/2018-06-20/migrant-children-comingus-are-being-sent-shelters-histories-child-abuse 
Boorstein, Michelle. "Trump Mentioned Two Holocaust Survivors During the State of the Union - Including One Who Also Survived the Pittsburgh Synagogue Shooting." Washington Post. February 5, 2019. https://www.washingtonpost.com/religion/2019/02/06/presidenttrump-just-mentioned-holocaust-survivor-who-survived-pittsburgh-synagogueshooting/?utm_term=.8932a3625a45.

Born, Georgina, and David Hesmondhalgh. "Introduction: On Difference, Representation, and Appropriation in Music.” In Western Music and Its Others: Difference, Representation, and Appropriation in Music, ed. Georgina Born and David Hesmondhalgh, 1-58. Berkeley: University of California Press, 2000.

Brennan, Timothy. "Hegel, Empire, and Anti-Colonial Thought." In The Oxford Handbook of Postcolonial Studies, ed. Graham Huggan, 142-161. Oxford: Oxford University Press, 2013.

Bushard, Anthony. "Waging the Peace: Bernard Herrmann and The Day the Earth Stood Still." College Music Symposium 49/50 (2009/2010): 314-326.

Büyükokutan, Barış. "Toward a Theory of Cultural Appropriation: Buddhism, the Vietnam War, and the Field of U.S. Poetry.” American Sociological Review 76, no. 4 (2011): 620-39.

Byrne, David. 'Crossing Music's Borders In Search Of Identity; 'I Hate World Music.'” New York Times. October 3, 1999. https://archive.nytimes.com/query.nytimes.com/gst/ fullpage-9901EED8163EF930A35753C1A96F958260.html.

Campbell, Colin. "Trump: 'I Use the Word Rape and All of a Sudden Everyone Goes Crazy.", Business Insider. July 6, 2015. https://www.businessinsider.com/trump-i-use-the-wordrape-and-all-of-a-sudden-everyone-goes-crazy-2015-7.

Campbell, R.M. “Kronos Quartet Performs Terry Riley's Sun Rings.” Seattle Post-Intelligencer. July 20, 2003. https://www.seattlepi.com/news/article/Kronos-Quartet-performs-TerryRiley-s-Sun-Rings-1119751.php.

Card, Orson Scott. Ender's Game. New York: Tor Science Fiction, 1994.

Care, Ross. "Klaatu Barada Nikto!: The Day the Earth Stood Still." Film Score Monthly 16, no. 6 (2011): 5 .

Carl, Robert. Terry Riley's In C. Studies in Musical Genesis, Structure, and Interpretation. New York: Oxford University Press, 2009.

Carter, Sarah. Capturing Women: The Manipulation of Cultural Imagery in Canada's Prairie West. Montreal: McGill-Queen's University Press, 1997.

CBC Music. "Chris Hadfield and Barenaked Ladies - I.S.S. (Is Somebody Singing).” YouTube. Uploaded February 12, 2013. https://youtu.be/AvAnfi8WpVE. 
CBC News. "Bin Laden Claims Responsibility for 9/11.” CBC. October 29, 2004. https://www.cbc.ca/news/world/bin-laden-claims-responsibility-for-9-11-1.513654.

—. "Chris Hadfield Interview." Interview by Peter Mansbridge. YouTube. Uploaded January 20, 2014. https://youtu.be/kGRXWtzWz-Y.

Cerullo, Megan. "Government-Funded Treatment Center Forcibly Injected Immigrant Kids with Drugs: Legal Filings.” The San Diego Union-Tribune. June 20, 2018. https://www.sandiegouniontribune.com/ny-news-drugging-immigrant-children20180620-story.html.

Cillizza, Chris. "Donald Trump Used a Word He's 'Not Supposed To.' Here's Why." CNN. October 23, 2018. https://www.cnn.com/2018/10/23/politics/donald-trump-nationalism/ index.html.

Coleman, Daniel. Masculine Migrations: Reading the Postcolonial Male in New Canadian Narratives. Toronto: University of Toronto Press, 1998.

Corbett, John. "Experimental Oriental: New Music and Other Others.” Western Music and Its Others: Difference, Representation, and Appropriation in Music, ed. Georgina Born and David Hesmondhalgh, 163-186. Berkeley, University of California Press: 2000).

Coren, Dan. "Kronos Quartet Plays Sun Rings.” BroadStreetReview.com. April 28, 2007. https://www.broadstreetreview.com/music/Kronos_Quartet_plays_Sun_Rings\#.

Crockett, Walter. "Sun Ra: Jazz Man from Outer Space." Worcester Telegram \& Gazette (MA), D1 (February 1, 1990).

Custalow, Linwood, and Angela L Daniel. The True Story of Pocahontas: The Other Side of History: From the Sacred History of the Mattaponi Reservation People. Golden, Colorado: Fulcrum, 2007.

DiBlasi, Alex, and Victoria Willis. Geek Rock: An Exploration of Music and Subculture. Lanham: Rowman \& Littlefield, 2014.

Dickerson, Kelly. "Here's What David Bowie's Song 'Space Oddity' is Really About.” Business Insider. January 11, 2016. https://www.businessinsider.com/david-bowie-song-spaceoddity-meaning-2016-1.

Downing, Karen. Restless Men: Masculinity and Robinson Crusoe, 1788-1840. New York: Palgrave MacMillan, 2014.

Duckworth, William. Talking Music. New York: Schirmer Books, 1995.

Dunietz, Jesse. “Space Prospecting.” Scientific American 317 (October 2017): 14-16. 
Durkin, Erin. "Space Force: All You Need to Know about Trump's Bold New Interstellar Plan." The Guardian. August 10, 2018. https://www.theguardian.com/usnews/2018/aug/10/space-force-everything-you-need-to-know.

Ertan, Deniz. Dane Rudhyar: His Music, Thought, and Art. Rochester: University of Rochester Press, 2009.

Fanon, Frantz. Les Damnés de la Terre. Paris: F. Maspero, 1961. Translated by Richard Philcox as The Wretched of the Earth (New York: Grove Press, 2004).

—. Peau Noire, Masques Blancs. Paris: Editions Du Seuil, 1953. Translated by Richard Philcox as White Skin, Black Masks (New York: Grove Press, 1967).

Farrell, Gerry. "Reflecting Surfaces: The Use of Elements from Indian Music in Popular Music and Jazz." Popular Music 7, no. 2 (1988): 189-205.

Featherstone, Simon. "Music." In Postcolonial Cultures, ed. Simon Featherstone, 33-64. Edinburgh: Edinburgh University Press, 2005.

Fiegel, E. Todd. "Bernard Herrmann as Musical Colorist: A Musicodramatic Analysis of His Score for The Day the Earth Stood Still." Journal of Film Music 1, no. 2/3 (2003): 185215.

Flow Motion. “Astro Black Morphologies: Music and Science Lovers.” Leonardo 39, no. 1 (2006): 23-27.

Forsdick, Charles. "Revisiting Exoticism: From Colonialism to Postcolonialism.” In Francophone Postcolonial Studies: A Critical Introduction, ed. Charles Forsdick and David Murphy, 46-55. London: Arnold, 2003.

Forsdick, Charles and David Murphy, eds. Francophone Postcolonial Studies: A Critical Introduction. London: Arnold, 2003.

Gandhi, Leela. Postcolonial Theory: A Critical Introduction, $2^{\text {nd }}$ edition. New York: Columbia University Press, 2018.

Gauthier-Villars, David and Margherita Stancati. "Erdogan Says Saudis Planned Murder of Journalist Jamal Khashoggi." Wall Street Journal. October 23, 2018. https://www.wsj. com/articles/turkeys-erdogan-saudi-journalist-was-murdered-1540287925.

Ghosh, Phallab. "Chris Hadfield Says NASA's Job is Not to 'Titillate."” BBC News. May 13, 2013. https://www.bbc.com/news/science-environment-22483934.

Gilroy, Paul. The Black Atlantic: Modernity and Double Consciousness. Cambridge, MA: Harvard University Press, 1993. 
Gorbman, Claudia. "Scoring the Indian: Music in the Liberal Western." Western Music and Its Others: Difference, Representation, and Appropriation in Music, ed. Georgina Born and David Hesmondhalgh, 234-253. Berkeley: University of California Press: 2000.

—. Unheard Melodies: Narrative Film Music. Bloomington: Indiana University Press, 1987.

Government of Canada. "The MAPL System - Defining a Canadian Song." Canadian Radiotelevision and Telecommunications Commission. August 10, 2009. https://crtc.gc.ca/eng/info_sht/r1.htm.

—_. "Radio Regulations, 1986." Justice Laws Website. January 1, 2018. https://lawslois.justice.gc.ca/eng/regulations/SOR-86-982/page-2.html\#h-7.

Graziano, John. "The Use of Dialect in African-American Spirituals, Popular Songs, and Folk Songs." Black Music Research Journal 24, no. 2 (2004): 262-63. doi:10.2307/4145494.

Grimshaw, Jeremy. Draw a Straight Line and Follow It: The Music and Mysticism of La Monte Young. Oxford: Oxford University Press, 2012.

Gryner, Emm. "May 12, 2013: Space Oddity in Space.” The Emmbassy blog. Internet Archive Wayback Machine. https://web.archive.org/web/20130811064625/http://www.emm gryner.com/emmbassy/?q=node/861.

Guerrero, Rodrigo. "The Role of The Beatles in Popularizing Indian Music and Culture in the West." The Florida State University Undergraduate Research Journal 5, no. 1 (Spring 2015), 32-41.

Gurnett, Donald A., and the University of Iowa. "Space Audio." Space-Audio.org. http://spaceaudio.org/.

Hadfield, Chris. An Astronaut's Guide to Life on Earth: What Going to Space Taught Me about Ingenuity, Determination, and Being Prepared for Anything. New York: Little, Brown and Company, 2013.

—_. "Ride That Lightning - Commentary." Space Sessions: Songs from a Tin Can. Spotify. https://open.spotify.com/playlist/2bMKEZzeJklXZwVvuGmp53.

_. "Songs About Space." Spotify. Uploaded October 8, 2015. https://open.spotify.com/playlist/799tsdWb2AvMKr3Yd6Oiph.

—. "We Should Treat the Earth as Kindly as We Treat Spacecraft." Wired. November 25, 2013. https://www.wired.com/2013/11/chris-hadfield-wired/.

Hahn, Miriam. "Playing Hippies and Indians: Acts of Cultural Colonization in the Theatre of the American Counterculture.” PhD Dissertation. Bowling Green State University, 2014. 
Hall, Jacob. "Interview: Arrival Composer Jóhann Jóhannsson on How You Score First Contact." Slash Film. November 11, 2016. https://www.slashfilm.com/johannjohannsson-arrival-music/.

Harrington, David. "Something Precious." Letters to the Future: The Paris Climate Project. https://letterstothefuture.org/letter/117/something-precious/.

Harris, Philip R. Space Enterprise: Living and Working Offworld in the 21st Century. (Berlin: Praxis, 2009).

Hawking, Stephen. Into the Universe with Stephen Hawking. Documentary. Directed by Darlow Smithson Productions Limited. 2010. Discovery Channel.

Head, Raymond. "Gustav Holst: The Planets Suite: New Light on a Famous Work." https://raymondhead.com/gustav-holst-planets.

Headlam, David. "Re-Drawing Boundaries: The Kronos Quartet." Contemporary Music Review 19, no. 1 (2000): 113-40.

Helmreich, Stefan. “Gravity's Reverb: Listening to Space-Time, or Articulating the Sounds of Gravitational-Wave Detection.” Cultural Anthropology 31, no. 4 (2016): 464-92. doi:10.14506/ca31.4.02.

Herndon, Astread W. "Elizabeth Warren Stands by DNA Test. But Around Her, Worries Abound." New York Times. December 6, 2018. https://www.nytimes.com/2018/12/06/us/politics/elizabeth-warren-dna-test-2020.html.

Hirway, Hrishikesh. "Song Exploder: Jóhann Jóhannsson on the Secrets of Arrival's Score." Vulture. November 17, 2016. http://www.vulture.com/2016/11/arrival-score-johannjohannsson-song-exploder.html.

Hogg, Robert. Men and Manliness on the Frontier: Queensland and British Columbia in the Mid-Nineteenth Century. Genders and Sexualities in History. New York: Palgrave MacMillan, 2012.

Holm-Hudson, Kevin. “Apocalyptic Otherness: Black Music and Extraterrestrial Identity in the Music of Magma.” Popular Music and Society 26, no. 4 (2003): 481-95.

Hook, Derek. "The Racial Stereotype, Colonial Discourse, Fetishism, and Racism." Psychoanalytic Review 92, no. 5 (2005): 701-34.

Horowitz, Sari, and Maria Sacchetti. "Sessions Vows to Prosecute All Illegal Border Crossers and Separate Children from Their Parents." Washington Post. May 7, 2018. https://www.washingtonpost.com/world/national-security/sessions-says-justice-dept-will- 
prosecute-every-person-who-crosses-border-unlawfully/2018/05/07/e1312b7e-521611e8-9c91-7dab596e8252_story.html?noredirect=on\&utm_term=.f705adc1ff78.

Huang, Francis L. and Dewey G. Cornell. "School Teasing and Bullying After the Presidential Election." Educational Researcher (January 2019). doi: 10.3102/0013189X18820291.

Huggan, Graham, ed. The Oxford Handbook of Postcolonial Studies. Oxford: Oxford University Press, 2013.

Huovinen, Erkki, and Anna-Kaisa Kaila. "The Semantics of Musical Topoi: An Empirical Approach." Music Perception 33, no. 2 (2015): 217-43. doi:10.1525/MP.2015.33.2.217.

Huss, Boaz. "Spirituality: The Emergence of a New Cultural Category and its Challenge to the Religious and the Secular." Journal of Contemporary Religion 29. no. 1 (2014), 47-60. doi: 10.1080/13537903.2014.86480.

Ireland, Brian and Sharif Gemie. "Raga Rock: Popular Music and the Turn to the East in the 1960s.” Journal of American Studies (2017): 1-38. doi:10.1017/S0021875817000925.

Ivakhiv, Adrian. "Nature and Self in New Age Pilgrimage." Culture and Religion 4, no. 1 (2003), 93-118.

Jet Propulsion Laboratory. "Voyager." NASA.gov. https://voyager.jpl.nasa.gov/golden-record/.

Johnson, Myke. "Wanting to Be Indian: When Spiritual Searching Turns into Cultural Theft." Unsettling American: Decolonization in Theory \& Practice Blog. September 20, 2011. https://unsettlingamerica.wordpress.com/2011/09/20/wanting-to-be-indian/.

Johnson, Robert. “Outer-Space Tunes Make Earth Debut in a Bar in Peoria --- Pianist-Singer Claims Aliens Taught Her their Music; Do They Get Royalties?” Wall Street Journal, September 4, 1990.

Josephson, Paul R. Resources Under Regimes: Technology, Environment, and the State. New Histories of Science, Technology, and Medicine. Cambridge: Harvard University Press, 2004.

Kay, David. “Score Analysis: What Makes Super 8 Super?” Film Score Monthly 16, no. 8 (2011): 30.

Keefe, Alexander. "Lord of the Drone: Pandit Pran Nath and the American Underground." Bidoun 20 (2010): 113-119.

Kronos Quartet. “Kronos Quartet performs Terry Riley's Sun Rings.” YouTube video. 16:42. Posted December 2012. https://www.youtube.com/watch?v=GUlMyYuEyXw.

—_. "Sun Rings.” KronosQuartet.org. https://kronosquartet.org/projects/detail/sun_rings. 
Kurth, Bill. “The Eerie Sounds of Saturn's Radio Emissions.” Space-Audio.org. http://wwwpw.physics.uiowa.edu/space-audio/cassini/SKR1/t2003_324_0625_skr_anim.html.

Kurth, W.S. "Waves in Space Plasmas.” Space-Audio.org. http://www-pw.physics.uiowa.edu/ plasma-wave/tutorial/waves.html.

Lanza, Joseph. "Violins from Space." Elevator Music: A Surreal History of Muzak, EasyListening, and Other Moodsong, 183-94. Ann Arbor: University of Michigan Press, 2004.

Leach Neil, ed. Space Architecture: The New Frontier for Design Research 84, no. 1. West Sussex: John Wiley and Sons, Inc., 2014.

Lerner, Neil. 'Nostalgia, Masculinist Discourse, and Authoritarianism in John Williams' Scores for Star Wars and Close Encounters of the Third Kind." Off the Planet: Music, Sound, and Science Fiction Cinema, ed. Philip Hayward, 96-109. London: John Libbey, 2004.

Locke, Ralph P. Musical Exoticism: Image and Reflections. Cambridge: Cambridge University Press, 2009.

Loomba, Ania. Colonialism/Postcolonialism, 3rd edition. London: Routledge, 2015.

“Mars.” SpaceX. Accessed April 20, 2018. http://www.spacex.com/mars.

Marx, Karl, Edward B Aveling, Friedrich Engels, and Samuel Moore. Capital: A Critique of Political Economy. Vol. 1, Book 1, the Process of Production of Capital. London: Electric Book, 2001.

McClary, Susan. Georges Bizet: Carmen. Minneapolis: University of Minnesota Press, 1992.

Mertens, Wim. American Minimal Music: La Monte Young, Terry Riley, Steve Reich, Philip Glass. London: Kahn \& Averill, 1983.

Miller, Paul. “An Adventure into Outer Space: Stockhausen's Lichter-Wasser and the Analysis of Spatialized Music.” Perspectives of New Music 50, no. 1-2 (2012): 342-92.

Mount, Dana and Susie O'Brien. "Postcolonialism and the Environment." In The Oxford Handbook of Postcolonial Studies, ed. Graham Huggan, 521-539. Oxford: Oxford University Press, 2013.

Morton, Stephan. "Violence, Law, and Justice in the Colonial Present." In The Oxford Handbook of Postcolonial Studies, ed. Graham Huggan, 179-196. Oxford: Oxford University Press, 2013.

Mosley, Stephen. The Environment in World History. Themes in World History. New York: Routledge, 2010. 
Moynihan, Ruth Barnes, Susan H. Armitage, and Christiane Fischer Dichamp. So Much to Be Done: Women Settlers on the Mining and Ranching Frontier. Women in the West. Lincoln: University of Nebraska Press, 1990.

Murphy, Paul. “Kronos Quartet,” The Musical Times 134, no. 1809 (1993): 617. doi:10.2307/1002796

NASA. "Women in Space." NASA History Office. 2017. https:/history.nasa.gov/women.html.

Nguyen, Christine and Will Wei, producers. "Astronaut on Aliens." Tech Insider. Interview with Chris Hadfield. Uploaded November 17, 2015. https://youtu.be/eeOZHDM-Lgc.

Nuzzi, Olivia. "How Trump Offered NASA Unlimited Funding to Go to Mars in His First Term.” Intelligencer. January 22, 2019. http://nymag.com/intelligencer/2019/01/trumpoffered-nasa-unlimited-funding-to-go-to-mars-by-2020.html.

O’Connell, Sharon. “Arrival Composer Jóhann Jóhannsson: ‘People are Hungry for New Sounds." The Guardian. November 26, 2016. https://www.theguardian.com/music/ 2016/nov/26/arrival-johann-johannsson-soundtrack-oscar-nominated.

Oja, Carol J. "Rudhyar, Dane.” Grove Music Online. 2001. http:////www.oxfordmusiconline.com/grovemusic/view/10.1093/gmo/9781561592630.00 1.0001/omo-9781561592630-e-0000024082.

Olmstead, Molly. "Report: Nearly Half of Funding for Child Migrant Care Went to Shelters with Histories of Abuse.” Slate. June 20, 2018. https://slate.com/news-andpolitics/2018/06/report-finds-long-history-of-abuse-in-child-migrant-shelters.html.

Patches, Matt. “The Mystery Line in Arrival, Revealed.” Thrillist. November 13, 2016. https://www.thrillist.com/entertainment/nation/arrival-chinese-line-ending.

Pearlman, Shaina. "Listen to the First Song Recorded in Space." Paste. December 28, 2012. https://www.pastemagazine.com/blogs/awesome_of_the_day/2012/12/listen-to-the-firstsong-recorded-in-space.html.

Pecotic, David. "Three Aboriginal Responses to New Age Religion: A Textual Interpretation." Australian Religion Studies Review 14, no. 1 (2001), 65-81.

Potter, Keith. Four Musical Minimalists: La Monte Young, Terry Riley, Steve Reich, Philip Glass. Cambridge: Cambridge University Press, 2004.

Potter, Tully. “Kronos Quartet.” Grove Music Online. January 2001.

Prasad, Anil. “Terry Riley: Lighting Up Nodes.” Innerviews: Music Without Borders. https://www.innerviews.org/inner/riley.html. 
Quintana, Chris, Teghan Simonton, and Megan Zahneis. "College Leaders and Professors Ramp Up Protest of Trump's Family-Separation Policy." The Chronicle of Higher Education. June 19, 2018. https://www.chronicle.com/article/College-LeadersProfessors/243714.

Ramnarine, Tina K. "Musical Performance in the Diaspora: Introduction." Ethnomusicology Forum 16, no. 1 (2007): 1-17.

Ramsay, Christine. Making It Like a Man: Canadian Masculinities in Practice. Cultural Studies Series. Waterloo, Ontario: Wilfrid Laurier University Press, 2011.

Rehding, Alexander. "Beethoven in Space." OUPblog. December 3, 2017. https://blog.oup.com/2017/12/beethoven-in-space/.

— , and Daniel KL Chua. "Earth Music.” Musicology Now blog. July 10, 2017. http://musicologynow.ams-net.org/2017/07/earth-music.html.

Richter, Max. "Millions of Us Knew the Iraq War Would Be a Catastrophe. Why Didn't Tony Blair?" The Guardian. July 8, 2016. https://www.theguardian.com/commentisfree/2016/ jul/08/iraq-war-tony-blair-creativity-chilcot-inquiry.

Riley, Terry. Liner Notes to A Rainbow in Curved Air. Columbia Masterworks Records, MS 7315. CD. 1969.

"Roadmap.” MarsOne. Accessed April 20, 2018. https://www.mars-one.com/mission/roadmap.

Robertson, Campbell, Christopher Mele, and Sabrina Tavernise. "11 Killed in Synagogue Massacre; Suspected Charged with 29 Counts." New York Times. October 27, 2018. https://www.nytimes.com/2018/10/27/us/active-shooter-pittsburgh-synagogueshooting.html.

Rosar, William H. "The Penumbra of Wagner's Ombra in Two Science Fiction Films from 1951: The Thing from Another World and The Day the Earth Stood Still." Wagner and Cinema, ed. Jeongwon Joe and Sander L. Gilman, 152-164. Bloomington: Indiana University Press, 2010.

Rosenboom, David. "Music Notation and the Search for Extra-Terrestrial Intelligence." Leonardo 26, no. 4 (1993): 273-74.

Ross, Alex. “The Spooky Fill.” The New Yorker 86, no. 13 (2010): 60-67.

Said, Edward W. Orientalism. New York: Pantheon Books, 1978.

Sankaracharya, Sri. Saundarya-Lahari. Ganesh \& Co., 2013.

Santianni, Michael. "The Movement for a Free Tibet: Cyberspace and the Ambivalence of 
Cultural Translation.” In The Media of Diaspora, ed. Karim H. Karim, 189-202. London: Routledge, 2003.

Savage, Donald. "NASA Music Out of this World," https://www.nasa.gov/home/hqnews/2002/ 02-207.txt.

Schneller, Tom. "Sweet Fulfillment: Allusion and Teleological Genesis in John Williams' Close Encounters of the Third Kind." The Musical Quarterly 97, no. 1 (2014): 98-131.

Schwarz, K. Robert. "La Monte Young and Terry Riley." In Minimalists: 20th Century Composers, 15-49. London: Phaidon, 1996.

Sharp, Joanne. "Africa's Colonial Present: Development, Violence, and Postcolonial Security." In The Oxford Handbook of Postcolonial Studies, ed. Graham Huggan, 235-252. Oxford: Oxford University Press, 2013.

Sheedy, Matt. "Some Post-Colonial Narratives on Spirituality and Yoga." Bulletin for the Study of Religion Blog. May 20, 2013. http://bulletin.equinoxpub.com/2013/05/some-postcolonial-discourses-on-spirituality-and-yoga/.

Smith, Geoff, and Nicola Walker Smith. "Terry Riley.” In New Voices: American Composers Talk About Their Music. Portland, OR.: Amadeus Press, 1995.

Smith, John. The Complete Works of Captain John Smith (1580-1631), ed. Philip L Barbour, 3 vols. Chapel Hill, NC: University of North Carolina Press, 1986.

Smith, Matt and Aura Bogado. "Immigrant Children Forcibly Injected with Drugs at Texas Shelter, Lawsuit Claims." The Texas Tribune. June 20, 2018. https://www.texastribune.org/2018/06/20/immigrant-children-forcibly-injected-drugslawsuit-claims/.

Southern Poverty Law Center. "White Nationalist." Southern Poverty Law Center. https://www.splcenter.org/fighting-hate/extremist-files/ideology/white-nationalist.

Spivak, Gayatri Chakravorty. "Can the Subaltern Speak?" In Marxism and the Interpretation of Culture, ed. Cary Nelson and Larry Grossberg, 271-313. Chicago: University of Illinois Press, 1988.

Stanglin, Doug. "Two Children have Died in US Border Custody This Month. Before That, None in a Decade. Why Now?" USA Today. December 27, 2018. https://www.usatoday.com/story/news/2018/12/27/us-mexico-border-deaths-guatemalanboy-girl-deaths-rare-occurrence/2420568002/.

"Statement by the President on International Holocaust Remembrance Day," whitehouse.gov, Statements and Releases, January 27, 2017, https://www.whitehouse.gov/briefingsstatements/statement-president-international-holocaust-remembrance-day/. 
Steiman, Harvey. "Sounds from Outer Space in Terry Riley's Sun Rings." Seen and Heard International. March 2016. http://seenandheard-international.com/2016/05/sounds-fromouter-space-in-terry-rileys-sun-rings/

Stimeling, Travis D. "Music, Place, and Identity in the Central Appalachian Mountaintop Removal Mining Debate." American Music 30, no. 1 (2012): 1-29.

Stoler, Ann Laura. "Reason Aside: Reflections on Enlightenment and Empire." In The Oxford Handbook of Postcolonial Studies, ed. Graham Huggan, 39-66. Oxford: Oxford University Press, 2013.

Stone, Ruth M., ed. The World's Music: General Perspectives and Reference Tools. The Garland Encyclopedia of World Music 10. New York: Routledge, 2002. https://search.alexander street.com/view/work/bibliographic_entity\%7Creference_article\%7C1000223919.

Strickland, Edward. "Riley, Terry." Grove Music Online. Oxford Music Online. Oxford University Press, 2018. https://doi.org/10.1093/gmo/9781561592630.article.23474.

Summers, Tim. "Star Trek and the Musical Depiction of the Alien Other." Music, Sound \& The Moving Image 7, no. 1 (2013): 19-52.

Tapper, Jake. "WH: No Mention of Jews on Holocaust Remembrance Day Because Others were Killed Too." CNN. February 2, 2017. https://www.cnn.com/2017/01/28/politics/whitehouse-holocaust-memorial-day/index.html.

Taylor, Dallas. "Loop Groups.” Twenty Thousand Hertz. Podcast audio. 2018. https://www.20k.org/episodes/loopgroups.

The Daily Show with Trevor Noah. Season 23, episode 136. "In Trump's Universe, Everyone Loves 'Space Force." 'Directed by Paul Pennolino. Interview by Michael Kosta. Aired on June 26, 2018, on Comedy Central. https://www.youtube.com/watch?v=LYQXBPUqN4.

Tsitsos, William. "Racial Transparency Theory Applied to Musicians who Claim to Be Aliens." Popular Music \& Society 37, no. 1 (2014): 22-32.

Taylor, Timothy Dean. "'Nothin' but the Same Old Story': Old Hegemonies, New Musics." Global Pop: World Music, World Markets, 39-68. New York: Routledge, 1997.

Toliver, Brooks. "Eco-ing in the Canyon: Ferde Grofè's Grand Canyon Suite and the Transformation of Wilderness." Journal of the American Musicological Society 57, no. 2 (2004): 325-68. doi:10.1525/jams.2004.57.2.325.

Trump, Donald J. @realDonaldTrump. “Crooked Hillary wants a radical 500\% increase in Syrian refugees. We can't allow this. Time to get smart and protect America!” Twitter. 
May 22, 2016, 12:38pm.

https://twitter.com/realdonaldtrump/status/734468447829004288.

_ "Refugees from Syria are now pouring into our great country. Who knows who they are - some could be ISIS. Is our president insane?" Twitter. November 17, 2015, 5:54am. https://twitter.com/realdonaldtrump/status/666615398574530560.

. "Today Elizabeth Warren, sometimes referred to by me as Pocahontas, joined the race for President. Will she run as our first Native American presidential candidate, or has she decided that after 32 years, this is not playing so well anymore? See you on the campaign TRAIL, Liz!” Twitter. February 9, 2019, 2:54pm. https://twitter.com/realDonaldTrump/status/1094368870415110145.

University of Iowa. Sounds of Space." Space-Audio.org. http://www-pw.physics.uiowa.edu / dag/sounds2.html.

. "Sun Rings: Kronos Quartet." Space-Audio.org. http://www-pw.physics. uiowa.edu/space-audio/sun-rings/.

__. "Voyager-2 PWS: Arrival at Jupiter." Space-Audio.org. http://www-pw.physics.uiowa .edu/voyager/v2pws_jupiter_arrival.html.

Van De Bogart, Willard. "Extraterrestrial Contact: Creating Xenolinguistic Sonic Messages for Extraterrestrial Communication - Ether Ship Electronic Music Orchestrations in the Anza-Borrego Desert." Technoetic Arts 12, no. 1 (2014): 47-73. doi:10.1386/tear.12.1.47_1.

Villeneuve, Denis, director. Arrival. DVD. Paramount Pictures, 2016.

Von Glahn, Denise. The Sounds of Place: Music and the American Cultural Landscape. Boston: Northeastern University Press, 2003.

Walker, Hunter. "Donald Trump Just Released an Epic Statement Raging Against Mexican Immigrants and 'Disease." Business Insider. July 16, 2015. https://www.businessinsider.com/donald-trumps-epic-statement-on-mexico-20157\#ixzz3fF897ElH.

Weintraub, Steve 'Frosty.' "Composer Jóhann Jóhannsson on Arrival, Preparing to Score Blade Runner 2049, and More." Collider. October 26, 2016. http://collider.com/johannjohannsson-arrival-blade-runner-2-interview/\#inspiration

"Welcome to the Domain of Terry Riley." TerryRiley.net. http://terryriley.net/enter.htm.

Wierzbicki, James. "Weird Vibrations: How the Theremin Gave Musical Voice to Hollywood's Extraterrestrial 'Others." Journal of Popular Film and Television 30, no. 3 (2002): 125135. 
Wong, Yuk-Lin Renita and Jana Vinsky. "Speaking from the Margins: A Critical Reflection on the 'Spiritual-but-not-Religious' Discourse in Social Work." British Journal of Social Work 39, no. 7 (2009), 1343-59.

Wood, Lawrence. “The Environmental Impacts of Colonialism.” Bridgewater State University Virtual Commons. Honors Program Theses and Projects. December 17, 2015. https://vc.bridgew.edu/honors_proj/119/.

Woodard, Josef. "Science, Art Share Stage in Sun Rings." Los Angeles Times. October 16, 2003. http://articles.latimes.com/2003/oct/16/news/wk-woodard16.

Yang, Mina. Planet Beethoven: Classical Music at the Turn of the Millennium. Wesleyan University Press, 2014.

Yoshida, Emily. "Let's Talk About the Ending of Annihilation." Vulture. February 23, 2018. http://www.vulture.com/2018/02/annihilation-movie-ending-explained.html.

Young, La Monte. "Pandit Pran Nath." Grove Music Online. Oxford Music Online. Oxford University Press, 2018. https://doi.org/10.1093/gmo/9781561592630.article.A2257147. 